
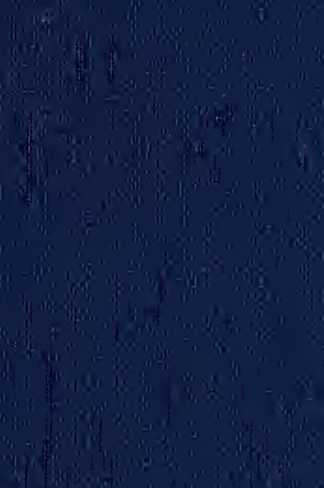

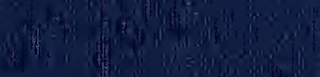

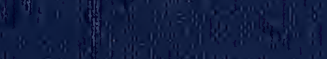

Nin $=4 y^{2}$ 

Digitized by the Internet Archive in 2011 with funding from

LYRASIS Members and Sloan Foundation 



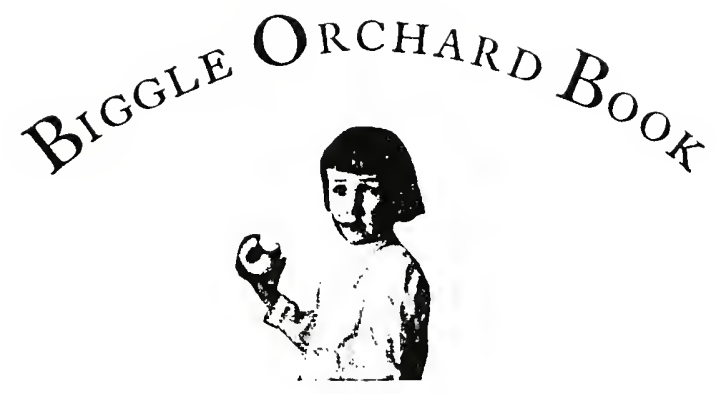

\title{
Fruit and Orchard Gleaningu
}

From Bough to Basket

\author{
Gathered and Packed Into Book Form \\ BY \\ JACOB BIGGLE
}

ILLUSTRATED

"Plant fruit trees. Who plants and tends a tree hath part in God's own work, and makes the earsh more beautiful."

Philadelphia

WILMER ATKINSON CO.

I 906 
COPYRIGHT, 1906

WILMER Atrinson Co.

$\longrightarrow$ 


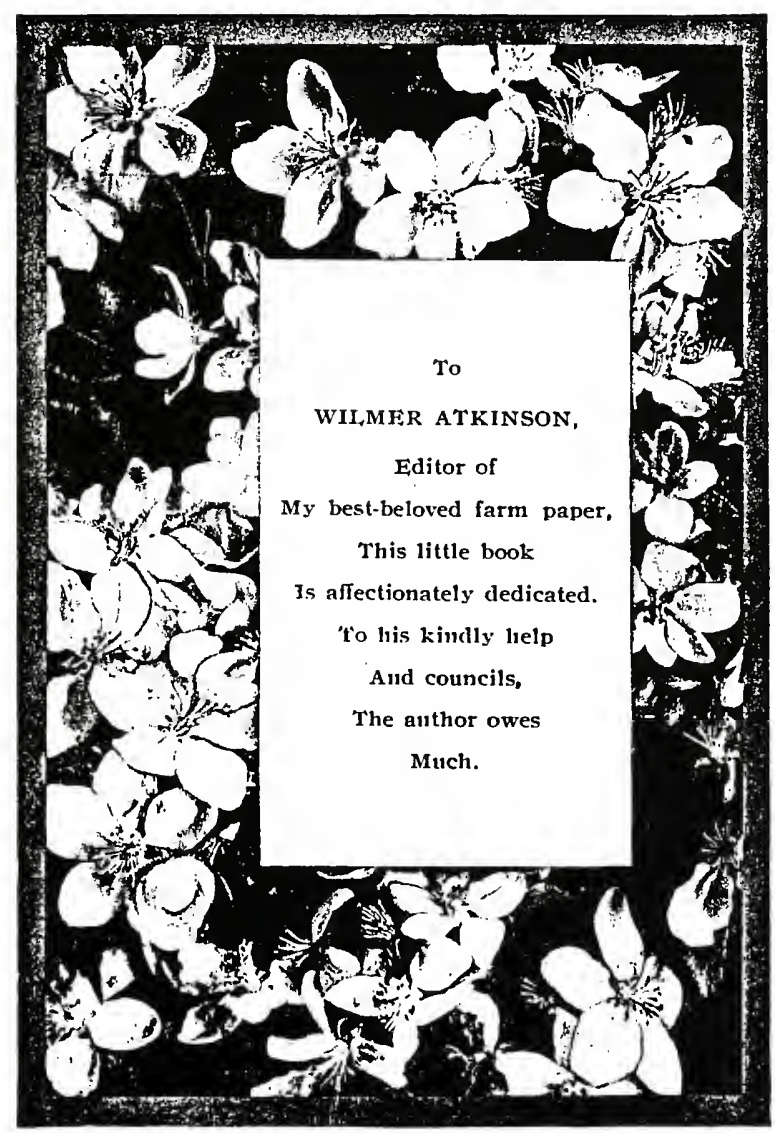




\section{ILLUSTRATIONS IN COLOR.}

(SPECial Note: All colored pictures are two-thirds natural size.)

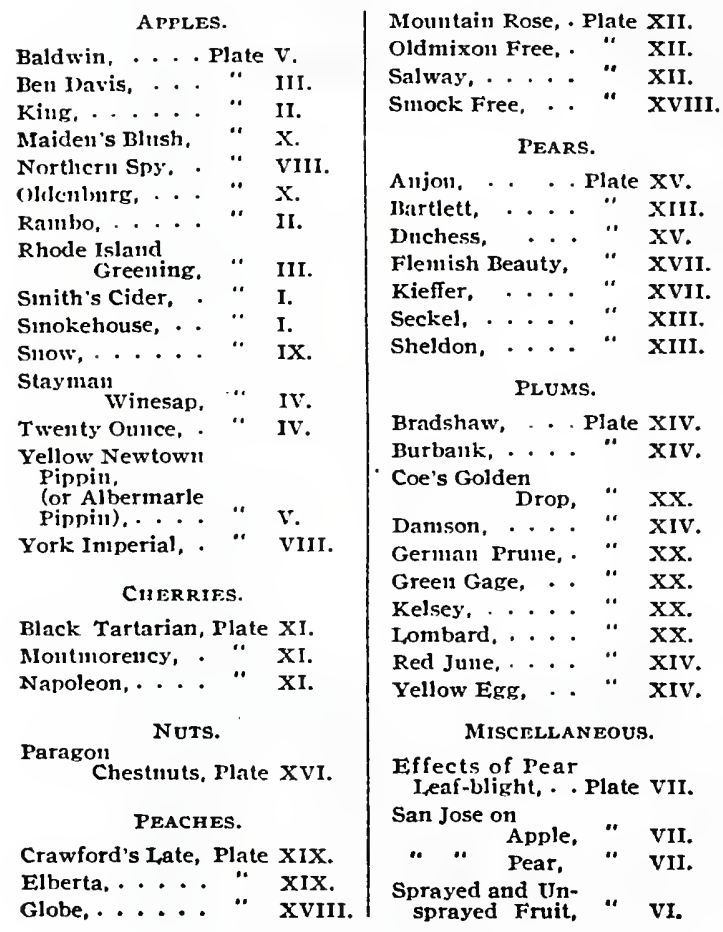




\section{PRLEACI:}

The writing of this little book has surely been a labor of love. Harriet and I love trees. They are our pets, and we think as much of them as we do of the animals and birds on the farm.

It hinl sometimes occurred to me that a need existed in this

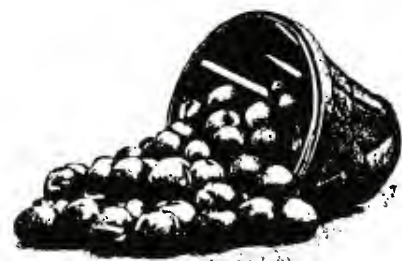
country for a simple, practical, inexpensive, boiled-down yet complete, printed talk on the snbject of tree fruits, - a talk that wonld help the amateur as well as the more experienced orchardist. My publishers encouraged the idea, saying that requests for such a treatise had often been received at their office during the past few years. Well-to make a long story short-this book is largely the result of their encouragement and kindness; witlout such helps I very much doubt whether the idea ever would have materialized into clear type.

IIarriet has helped me, too-bless her heart. So have Tim and Farmer Vincent. And so have the artists, designers, engravers and photographers who are connected with the Wilner $A$ tkinson Co.

Yes, and my thanks go ont, also, to the various practical fruit men, government experts, and writers, whose helpful suggestions, letters, pictures and 


\section{CONTENTS.}

PAQE

ChaP'TSR 1. Starling an Orchard: I'lanning 11

Chapter II. Seel-Growing, Grafting and

Budding . . . . . . . 19

Chapter III. Setting Trees . . . . . . 29

Chapter IV. Pruning and Early Care of

Newly-Set Trees . . . . 37

CHapter V. Later Pruning . . . . . 45

Chapter VI. Cultivation. Fertilization.

Thinning . . . . . . . 51

Chapter VII. Spraying . . . . . . . 59

Chapter ViII. Scale I'ests : San Jose, Oyster-

Sliell, Scurfy, etc. . . . 67

Chapter IX. Cover Crops. Fall, Winter

and Spring Care . . . 75

Cilaptrik X. Tlie $\Lambda$ pple . . . . . . . 81

Ciraptrr XI. The Cherry . . . . . . 91

Chapter XII. The Peach . . . . . . 95

Chapter Xili. The Pear . . . . . . . 101

Chapter XIV. The Plum . . . . . . . . 107

Cirapter XV. The Quince and Dwarf Pear . 111

Chapter XVI. Nut'l'rees . . . . . . . 115

Chapter XVII. Citrus and Other I'ruit l'rees 119

Chapter XVIII. Picking Fruit. . . . . . 123

Chapter XIX. Grading and Packing . . . . 129

Chapter XX. Cold Storage and Marketing - 137

(9) 
bulletins have been of aid to me in the preparation of this volume. At times, too, I have been glad to consult Prof. Bailey's Cyclopedia of American Ilorticulture, 'Thomas' American Fruit Culturist, Barry's linit Garden, and other standaral reference books. Aud I an indebted to II. W. Collingwoud, lislitor of the Ruril New-Yorker, for permission to reproduce the excellent dwarf pear ploto-engraving in Clupter XV; and to K. L. Harriman, of the Pilgrim Magazine, Battle Creek, Micl., for his courtesy in allowing me to use the peach-grater picture in Chapter XIX. Occisionally I liave used extracts from letters and from Experiment Station or Department of Agriculture literature, but, in the main, this Orchard Book embodies nuy own experiences, observations and conclusions-the result of a lifetine of practise and study.

My friend, Wilner $\Lambda$ tkinson, claims that his paper is "Unlike any other." Ile's right, too. It is. And, following a good example, I have tried to make this book different froni any other. It isn't an encyclopedia; it isn't a long-winded two or three dollar text-book; it isn't an incomplete pimphlet; it isn't hard to understand; and it isn't a reliash of other people's guesswork. No. It's simply a plain little book that aims to tell the inquiring reader just what he or she needs to know-no wore, no less. I have tried to have all the necessary facts set down and all the unnecessary things left ont. It's boiled-down "essence of orchard," served with picture trimmings, and side dishes of the finest colored plates ever put into a horticultural book. I hope you will like it, and that your orchard may prosper accordingly.

Elmwood, 1906.

JACOB BIGGLE. 


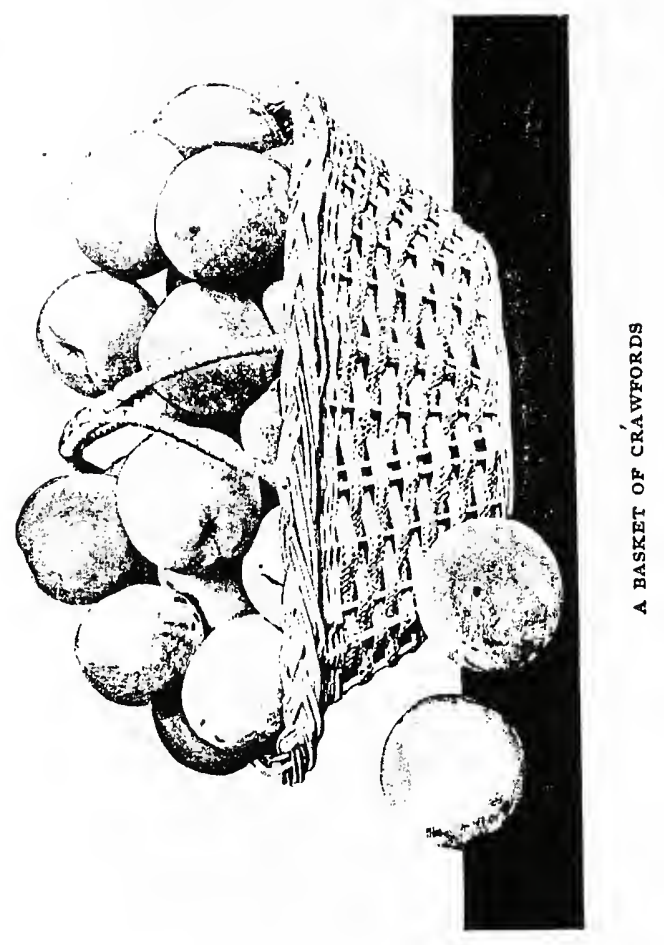




\section{Chapter I.}

\section{STAR'IIN(' $\triangle N$ ORCIIARI): PLANNING. \\ If a man dossn't start. If will nerer get anyzuhere.-'Tim.}

'The first thing to rlo abont starting an orcliaril is to plin for it. I'nt on your tlinking-cap, study into the matter, and lo not jump ill the dirk. $\Lambda$ slow start is much better than a poor start. IIarriet says that an orcliard set in the riglit place, at the right time and of the right varieties, is

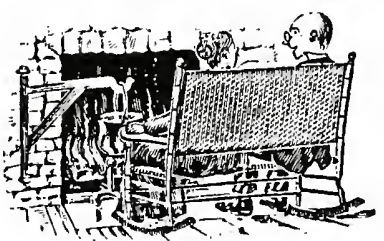

PIANNING THE ORCIIARD worth just "eleven times" more than a hit-or-miss orchard. (IVhere slie secured the data for sucli exact figures, I (lo not know; but I an willing to admit that slie is alont right in this statement.)

'lo begin, suppose we consicler the question of "riglit place." The icleal spot for a proposed orchard is gently sloping and high. 'This doesn't mean that it must be on top of a monntain. No. It means only comparatiz'e lieight. The spot sliould be somewhat higlier than its surromulings. That is the iclea. Then when a frost comes-or a deluge-it quickly runs of on to the lower lands. l'roper frost drainage is just as important as good water drainage. More so. Why? Because water can be tiled away; frost can not. Some growers prefer a nortl or some other slope; but (11) 
heiglit of land is of nore inportance than direction of slope.

Another thing to consider carefully, is the local clinute and conditions connected therewith. For instance: Before setting a commercial orchard of, say, peach trees, look around and ascertain whetlier the natural local conditions are favorable to that particular fruit. Is the locality a "peach section"? Are

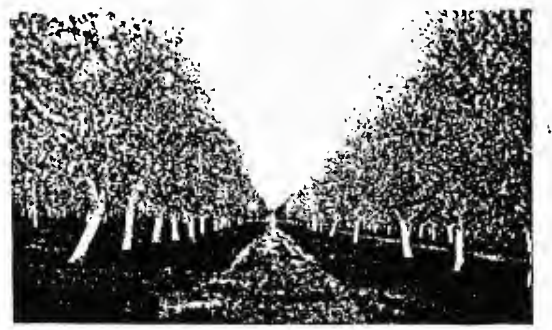

ISN'T SOMETHING LIKE THIS WORTII PLANNING FOR?

there successful peach orchards already established? Is the average winter cliniate mild enough for this somewhat tender fruit? Does the state experinent station advise the planting of peaclies in your locality? Do near-by practical fruit-growers advise it? If the answer to each of these questions is, "No," the chances are that you will be wise to cliange your plans and plant some other species of fruit,- some kind which is exactly adapted to the locality. The same rule holds good (to a greater or lesser degree) with other fruits. 
Other local conditions to consider, before setting a commercial orchard, are transportation, marketing facilities, and the help problem. In some localities it is possible to employ transient help just when most needed,-men for picking (for examplè), or women for packing; in other localities it is almost impossible to secure such temporary assistance.

Carefully study the question of soil in its relation to the frnits, etc., to be grown. Some kinds of fruit do best on light soils, some do best on heavy soils. The difference between a sandy or a clayey locition nity mean the difference between success ind fitilure. In this book will be founcl, in the special chapter levoted to each kind of fruit, etc., hints abont the soil best suited to the species.

The foregoing suggestions apply with most force, of course, to large orchards

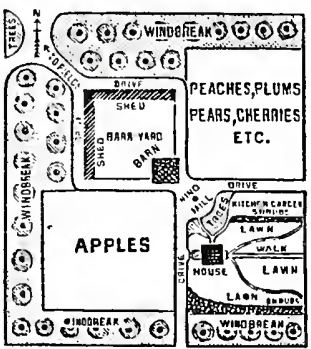

SUGGFSTION FOR HOMEORCIIARD ARRANGEMENT planted for market purposes. The home orchard for fanuily use necessarily means an aggregation of various kinds of trees probably all set together on one kind of soil, and therefore it is not in this case always possible to cater to all the requirements of each. But it pays to do so, as nearly as is practicable, even witlı a small family orchard.

Examine the subsoil. Is it so hard and so near the surface that tree roots can never hope to find a secure anchorage? Does water stand above the 
subsoil in such quantity and with such persistency as to threaten "wet feet" to the trees? If the former, seek another location; if the latter, make up your mind to tile the field before setting the trees. 'There are few orchards which are not the better for a system of nuderground drains. Better do the necessiry tiling at the start, rather than later. IIave the tile buried three feet (leep, and, if possible, lay it midway between tree rows.

Now let us consiler the question of the "right time." Generally speaking, early spring is the best season to set an orchiıri. 'llicre are some exceptions to this, of course. lior instiuce: Sweet clierry trees often grow better when set in the fall. Some of the more hardy fruits-apples, pears, etc.,-may be planted in antumn, if desired. Latitude has much to do with this question. The farther sonth you are, the safer it is to practise fall planting.

In the north, however, it is selilon wise to set tender trees, like peaches or plums, until spring; therefore the best rule I can give to the planter who isn't an expert, is: Stick to spring planting. Tim silys thit it's "better to be safe than sorry," and I an sure he is not fur wrong.

But it is usually gool policy to purchise trees in the fall, "heel" them in near the proposed orchard, and thus be ready for instant action when the ground gets into workable shape in the spring. The fall buyer gets first clioice of trees, and runs no danger of delayed spring slipments. Or, buy the trees in the fall, and let the nurseryman keep then for you until winter is over. 
How to "lieel in" trees: Dig a trencl, about a foot and a lialf deep, the same in widlti, and as long as may be necessary; if possible, clioose a lighl, sheltered, well-drained spot. Untie the bundles of trees, and place then loosely along the trencli, - each varicty by itself, properly labeled. Ilall-ildozen trees to a rmming

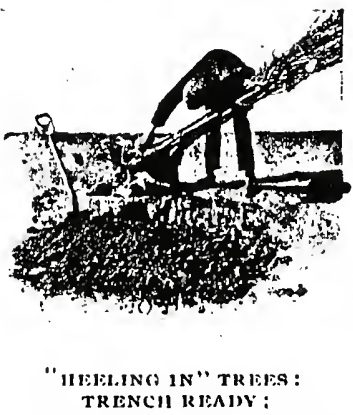
UNTYING NURSTKY HUNDIE foot is close enongh. Of contse put the roots in the trench; then incline the trees backward until they are "half lying down" across the excavation. Now shovel in fine dirt, carefully firm it into place, and pile the remaintler of the excavated dirt well up around the roots and lower portion of trunks. If the climate is rery cold, or if rabbits and mice are feared, eartl can be piled still higher up around the trunks and perhaps even around the lower branclics. If large quantities of trees are to be

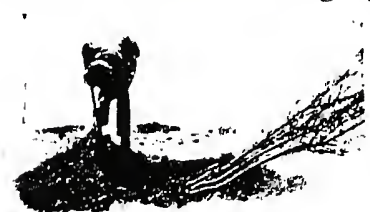

"HEEI.ING IN" OPEKATION COMPLETED, EXCEHT SHOVELING SOIL IN PLACE: "lieeled in,"'work is lessened and matters sinnplified if elose-together parallel trenclies are used instean of a single long one, using the dirt from eacli new trench to cover the preceding one. Drain the water away from the trenches. 
I earnestly advise all intending tree planters to visit the nearest reliable nursery and personally select the trees wan ted. Pick ont straiglit, liealthy, properlybranclied, thrifty trees. Medinm-size trees are usually best. Of course they sliould be fumigated and guaranteed free from scale. (They should also be dipped at home in the lime, stuphur and salt mixture, to make assurance doubly sure.)

But perliaps you nuy prefer to grow your own trees, instead of buying them already grown. If so, yon will find directions for seed sowing, budding and grifting, in the next cliapter.

$\Lambda$ t last we have come to the matter of "right varieties." And this is a very important nuatler, indeed. So important, in fact, that if it requires a year of preliminary study and inquiry to decide the matter rightly, it will be time profitably spent.

Stutly the various fruit cliapters in this book, wherein I have endcavored to give desirable lists of varieties for different localities. Write to your state experiment station, mentioning the nature of your soil, and ask for special advice as to the best varieties for you to plant; and be sure to state whether your orchard is wanted for market or family purposes. 'Talk with practical fruit-growers in your locality. Consult with your market buyers (if you are to have a commercial orcliard), or with your family's taste (if it's to be a lione orcliard).

Also, before buying or planning an orcliard or ordering trees, study these facts about pollination of blossons: Much of the musatisfactory fruiting of orchards all over the comntry is due to self-sterility. A tree is self-sterile if it can not set fruit unless planted near other varieties. The nain canse of 
self-sterility is the inability of the pollen of a variety to fertilize the pistils of that variety. An indication of self-sterility is the contimed dropping of young fruit from isolated trees or solid blocks of one variety; also, fruit from a self-sterile tree is apt to be imperfectly formed. Self-sterility is not a constant cliaracter with any variety. Poorly-11onrislied trees are more likely to be sterile with their own pollen than well-fed trees are. The loss of fruit from self-sterility may be prevented by planting other varieties anong the self-sterile trees, or by grifting other varieties into occasional trees. lior names of varieties which are often selfsterile, consult each special fruit

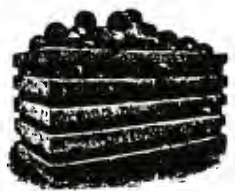
cliapter in this book.

"Getting the gromul realy for the tree-setting is anotler inuportant part of "starting an orchatrl." If possible, plow it in the fall. $\Lambda$ t lcist, it should be plowed previous to planting. Harrow it until the field is fine and level.

If the gromnd was in sod last year, better grow potatoes and subche the grass previons to setting trees. Preliminary fertilizing may or may not be necessary or desirable. If the land is fairly fertile, I slionld prefer, ordinarily, to apply mannre or fertilizer after the trees are planted, rather than before-' tis more economical. (See Cliapter VI for furtlier fertilizing facts.)

It is a good idlea to make a plan of the orchard, drawn to scale, and nuark thereon jnst where eacl tree is to go. ' 1 is is a great help when figuring ont how many trees to bny, or when setting the trees, or in after years when somebody asks: "What's the name of this tree?" 


\section{DON'Ts.}

Don't plan to start an orchiard on sod.

Don't waste moncy in buy ing "big" trees.

Don'tallow that you know it all: consult with the other fellow.

Ion't locate an' orchard on or very near the stcep hank of an al)rupt, decp ravinc. A big gully often acts like a frost trap.

Don't plan to set large, solicl blocks of trees of any one variety. Betler alternate several varieties in double rows.

Inol't forget that trec roots are not improved by exposure to whine or sun. Den't let them dry out. mululy, lefore "lieeling in " or planting. Frotect an newly-dug tice ns you woult a luthy.

Don't neglect to plan for the planting of a windhreak on the north and west sides of the orchard,-lint not too close; alont forty feet distant will do. Scotch pine or Norway spruce makes a good shelter.

The orchardist who figures the "possible net profit from one tree," and then multiplies that sum by the number of trees in the orcliard, is usually storing up disappointment. Orchards, like chickeus, seldom hatch ont a crop exactly "according to rule."

Don't figure on " novelties," nor varieties that the market doesn' $($ want; nor varieties that are already overplanted. Plant few kinds for market, rather than many kinds. Remember that large, mniform lots can be sold to better advantage than an nssortment of many" varicties. "Carloal lots" always command attention.

Don't forget that the near presence of large boties of water (preferably to the windward of the orchard), is oflcin an innportant factor in the production of tender varieties of fruit. For example: Peaches, etc., are successfully grown on the east bank of I,ake Michigan, and not on the west bank; and, on the east lank, the erop is nore sure within three miles of the lake than it is farther inland.

The age at which different fruit trees begin to bear molerately profitable crops varies greatly accortling to soil, climale, culture and variety, but perhaps a fair average would be: Apples, in tell or twelve years from setting (Spy, Spitzenburg, Rambo, Seek-nofurther, etc., are very slow); cherries, five or six years ; oranges and lemons, eight or ten years; peaches, fonr or five years ; pears (standard), ten or twclve years ; pears (dwarf), four or five years ; plumis, five or six years: quinces, five or six years. 'The peach is usually the shorlest lived of all fruit trees, - twelve or fifteen years is about the avcrage limit. 



\section{SMITII'S CIDER}

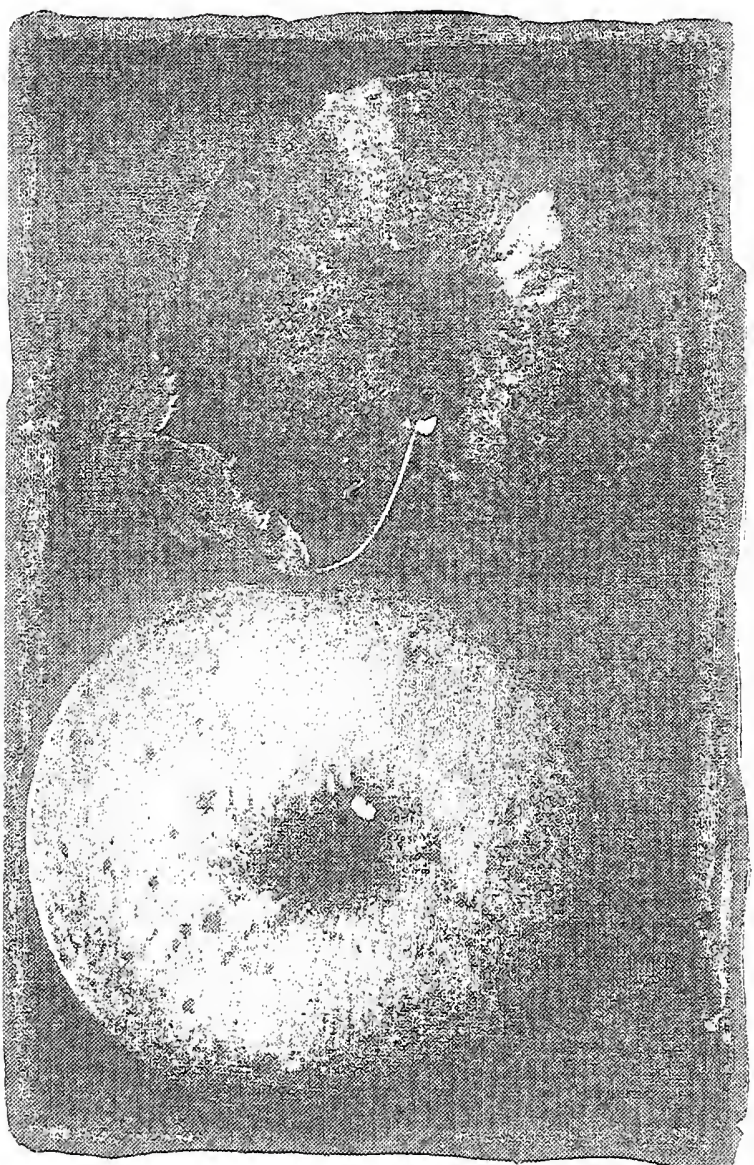

SMOKEHOUSE 


\section{CIIAPTHR II.}

\section{SEED-GROWING, GRAF'TING ANI BUDDING.}

Forzord in the name of God: Jlant, sraft and nomish np taces in your grould, the labor is small. threost is nothins, the commodity is grcal; yoursclers shall haz' plenty, llhe poer slath haze somezhat in time of want, and God shall walld your good merits and diligence.-1:rom an old English orchard book.

Nearly all orcharl trees come from seeds originally planted in nursery-beds, and later, after being budded or grafted, transplanted to the orchiard. 'Nhey are in fact usually transplanted once or nore before being finally put out in the orchard,-except in the case of the chestnut, hickory, etc., which object to being trinsplanted and are more easily grown by planting the nuts where the trees perminently belong.

To those accustomed to sowing flower and vegetable seeds it is often a surprise to find that tree seeds do not germinate so readily as the others. It is a fact that they do not. Still, fair snccess maty be looked for by attention to the preservation and sowing of the seeds.

Joseph Mechan says:-" $\Lambda$ s a rule, all kinds of seeds of trees are the better sown in antumn. As soon ats the seeds are ripe, keep then in a cool place and in sand so that they will not lose weight by drying. If in a building not exposed to winds, it will be a suitable place. Apple, cherry, peach and the whole list of such trees are included. Nurserymen who raise trees by the millions follow this plan. 
"'The seeds are sown in beds, usually four feet in width, the seeds well covered, as any otler seeds would be. A covering of forest leaves, straw or like material is placel over the beds, kept in place by adding branches of trees, sticks or prepared slats. This covering is taken off gradually in spring, as the seeds germinate.

"Should $\mathrm{jt}$ be inconvenient to sow in autumn, the same result may be expected from spring sowing, but the seeds must be properly preserved. There must be no loss of weight throngl the winter; the seeds must be as fresh in spring as when gathered. To accomplish this, either keep them in a damp cellar or mix them with slightly diump soil and keep in a cool cellar or room. What is required is that the seels absorb a little moisture insteat of losing any, and this the slightly dauı soil permits of. When so preserved, sow them the very first thing in spring, just as soon as the frost leaves the gromul. There need be no covering of leaves or stritw to spring-sown beds.

"Nurscrymen prefer antuun planting, except for lickory-nuts, walnuts and a few suclı seeds which mice are apt to get away with, and these they sow in spring.

"For autumn sowing, any time before the ground freezes will do, but be sure the sceds are not drying in the meintime. Seasons following sowings liave much to do with the vegetation of tree seeds, and even experts sometimes fail to secure a crop."

IMPORTANCE; OF GRAFTING.- Were all formis of the art of grafting and bulding to be taken from the lorticulturist tolay, commercial fruit growing in its 
lighl state of perfection wonld decay with the orchards now standing. All the common ponnaceons fruits (apples, pears, and quinces), the stone fruits (peaches, plums, cherries, and apricots), and the citrus fruits (lemons, lines, ancl oranges), are now multiplied by grafting or budling. 'The progress in plant breeling and the great rapidity with which new sorts are now disseminated could not be attained without the aid of budding or grafting.

The Scion and I'Ts 'IRIA'TMENT. - A scion is a portion cut fron a plant, to be inserted upon another (or the same) plant, with the intention that it shall grow. The wood for scions sliould be taken while in a dormant or resting conlition. The tine usually considered best is after the lcaics have fallcn, but b'fore sczere freczing bogins. The scions slonld be cut in abont six-inch lengths from matured new wood from bearing trees of known variety; then tied in bunches and placed in noist sand, where they will not freeze and yet will be kept cold enough to prevent growth. Good results nily follow culting scions in the spring just before or at the time the grafting is to be done, but it is a much better plan to cut the scions in the fall.

THE STOCK and ITs Treatment.-The stock is the tree or part of a tree upon which or into which the bud or scion is inserted. I'or best results in grifting it is essential that the stock be in an active, growing condition.

How To ClEF'T GRAFT. -When in the spring the sap begins to move in the stock, be ready; this occurs early in the phim and cherry, and later in the pear 
and apple. Do the grafting, if possible, on a mild day during showery weather. The necessary tools are a chisel or a thick-bladed knife or a grafting iron (with which to split open the stock after it is sawed off smoothly will a fille-tooth saw), a hanmer or mallet to aid the splitting process, a very sharp knife to trim the scions, and a supply of good grafting wax.
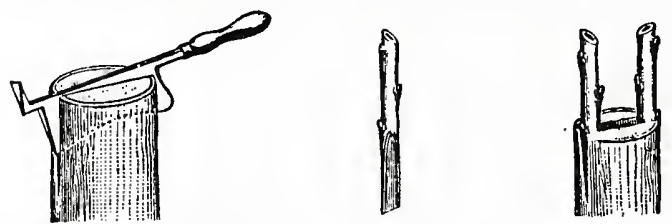

SPLITTING THE STOCK

TRIMAED SCION SCIONS INSERTED

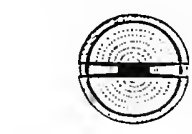

SECTIONAL

TOP VIENV OF SCIONS IN PLACE

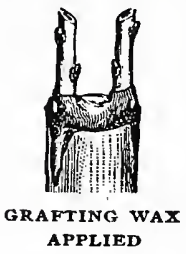

APPLIED

CLEFT GRAFTING : FROM START TO FINISH

Saw off a branch at the desired point, split the stock a little way down, and iusert a scion at each outer edge - taking care that the inner bark of the scion fits snugly and exactly against the inner bark of the stock. This-together with the exclusion of air and moisture until a union results - constitutes the secret of success. Trim the scions wedge-sliaped, as sliown in the picture; insert them accurately; the wedge 
shonll be a trifle thicker on the sille which comes in contact with the stock's bark. Iastly, apply grafting wax. I:ich scion shonld be long enongli to lave two or three buds, with the lower one placed as shown. The "spring" of the cleft holls the scion securely in place, and therefore tying slould be munecessary. If both scions in a cleft grow, one may later be cut away.

GRAFTING WAX.- - To four pounds of resin and one of beeswax ald one pint of linseed oil ; put in an iron pot, slowly heat and mix well. Ponr ont into cold water and pull by hand until lighit-coloreel. Keep in a cool place. fo use, oil the hamds, work the wax until soft, and apply aromil scions and cracks. If weather is warm, occasionally moisten hands in cold water.

Another recipe: One pombl of resin, one-lialf pound of beeswax and one-quarter ponnd of tallow, melted together and applied with a brush. Keep in an iron pot; heat for nse when wanterl.

OTHER METHODS OF GRAFTING.-There are many other methods of uniting scion and stock, a few of which may be briefly mentioned, - althongl the average orchardist seldom has use for methods more complicated than the ordinary cleft graft :

Bark grafting: $A$ branch is sawed off, as for cleft grafting, and the scions, instead of being inserted in acleft, are cut very thin and slipped between the bark and woorl, being inserted

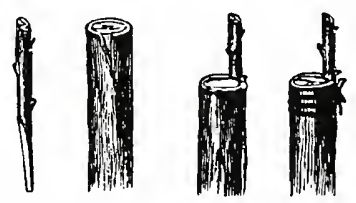
HOW BART GRAFTING IS DONE 
far enougl to bring the growing parts together. 'The bark is then securely bound and wax is used as in cleft grafting. It is an excellent method for grafting large limbs, as it injures the stock less than cleft grafting.

Brilge grafting, so-called, is werely

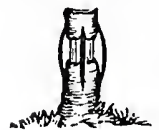
a methol for saving a girdled tree. Several npright scions are inserted in the bark, at top and botton, thins fur-

BRIOGE nishing brilges or conncc-

GRAFTiNG tions throngli which the sap can flow. A gool coiting of grafting wax is then applied. If all goes well, the tree grows a new bark on the gircled part. The illustration explains the operation fully.

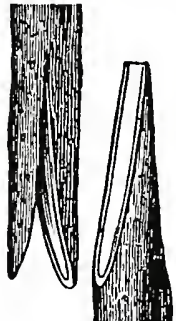

Crown grafting refers merely to a grafting opera-

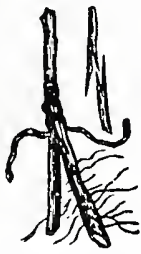
tion (ainy style) performed on the stens at or near the surface of the ground.

Root grafting means the insertion of a graft in a stock whicl is entirely a root.

Sithle grafting is plainly shown in lig. I.

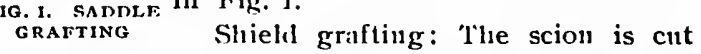
very thin, as in bark grifting, and is inserted nucler the bark of the stock as a bud is inserted in the process of budding, and is firmly bound in place with waxed cord or raffia.

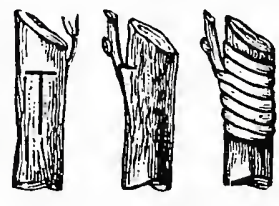

SIIELD GRAFTING 
Sicle grafting: See illustration. $\Lambda$, $B$ and $C$ show how it is done.

Splice grafting is very simple. It is like whip grafting, minns the mortising. The two diagonally cut encls are fitted together ("spliced") and then held in place by a waxed tie.

'lop grafting means, simply, the inserting of scions (by any desired method) in the branches of trees.

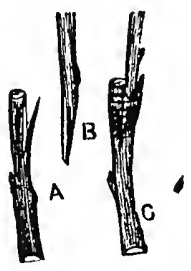

SIT) GRAITING

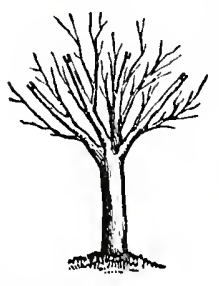

FIG. 11

Many a worthless tree has thins been clianged into a clesirable variety. By nsing enongh scions it is possible to make an entire new top on almost any tree. See Iíig. II, and study the idea slown there. It is not best to cut away too much of the old tree at once; therefore, a few seconclary branches are left, and Makinganew tor these, after the scions are thriftily growing, can gradually be cut away the following season.

Whip grafting, also called "tongue grafting" (see Fig. III), consists of an exict "dovetailing" of scion into stock. Nurserymen nse this method in special cases, and often in root grafting.

THE ART OF BUDDING.-This consists in taking a bul from one tree and inserting it under the bark of some other tree, says Farm Jonrnal. The union of the two, the bud and the stock, takes place at the

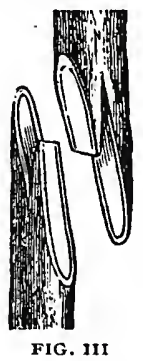

WIIT GRAPTING 
edges of the bark of the inserted bud. For this reason the bud should be inserted as soon as cut from its twig and before it has had time to dry out. The bud should also he full, phump and well matured, and cut from wool of the current scason's growth. 'l'he stock - shonld be in active growth so that the bark will slip easily. In cutting the bud a sharp knife is required,

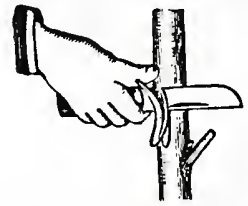

COTTIYG A RUD FROIA A BUDSTICK

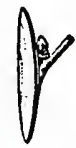

AND INSERT TIIS HUD

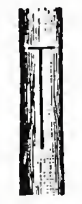
INCISION IN STOCK

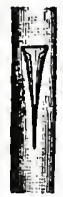

RAISE THE BARK, THUS

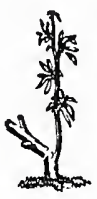

NEXT SEASON CUT AWAY TIIE STOCK, THUS

BUDDING: HROM A TO $\mathrm{Z}$

as a clean, smooth cut is desirable. The knife is inserted a half inch above and bronght ont the same distance below, shaving ont a small werlge of wood mucler the bud along with the bark. This wedge is no hindrance to the mion and should not be removed. The leaf is always clipped off.

To insert bul, make a 'T-shaped incision just throngl the bark of stock, as shown in the illnstration. Raise the bark carefnlly withont breaking it 
and insert the bud. Practise will give ease and despatch to the operator. The bud must be held firmly to the stock by a bandige wonnd about the stock both ahove ant below it, being careful to leave the eye of the bud nucovered. Rafiat, hast, cindlewick or waxed cloth mily be nsed for tying. In alsont ten diys, if the bud "takes," the bandinge nunst be removed, or the stock will be strangled and its growth hinclered. The work of buclling is usually perforned in July or Angust in the North, and in June in the Sonth. "Ihen the bark pecls casily and the weather is dry and clear, is the idcal time.

There are other methouls of performing this bulding operation, but the one described is in most common use. Uswally the buds are inserted in young scedling trees at a point close to the ground. This donc, the operition is conplete mitil the following season, when all the trees in which the huils hive "taken" sliould liave the top cut off just above the bud. (See illustration on page 26.)

BUDDING AND GRAFTING Compared. - The removal of the top forces the entire strengtli of the root into the bucl, and, since the root itself lias not been disturbed by trinsplanting, a nore vigorous growth nswally results from the bud than fron scions in grafting.

The one onjection to budding is that it canses an unsightly crook in the bocly of the tree, nuless the tree is afterward planted deep enongh in the orchard to cover the deformuity.

The best methods of propagating eacli kind of fruit will be fonnd in the special cliapter relating to that particular kind. 


\section{SPROU'TS FROM EXPFRIENCF.}

Repeated freezing and thawing while in a moist condition is destructive to most seeds.

'lin says that orchard graftcrs are the only kind of grafters who don't get into tronble nowadays.

Be sure that your top grafts are not choked out by being overshaded or interfercal with hy growth from the stock. If lice appear, soak the pests with strong tolncco-ten; do this early, before the leaves curl and hicle the insects.

cherry, peach and otlee pits shonld net be allowed to dry much after they are taken from the fruit. Wash then clean, dry in the sluade sufficiently to prevent mold, and then stratify, or store as directed in the beginning of this chapter.

No use to attempt the grafting or buclding of unrclated fruits; the pomaccous fruits, the stone and the citrus kinds, are familics by themselves. lior example: 'The pear works nicely on the pear, better on the guince, and not so easily on the apple, bint you can't induce it to grow on the cherry or the plum. And vice versa.

Nurserymen frequently practise what they call "stratification" ; it consists in plncing layers of scels alternating with laycrs of samd in a slallow loox. This box may be turicl or it may be set in a sheltered place and covered with leaves or straw to the depth of a foot. I'tic oliject is to soften and clecay the hard covering witlout starting germination. Freezing is beneficial in case of walnuls, lickory-nuts, pcach pits, and the like, as it helps to crack the shells. Hence such seeds are sometimes stratified in boxes placed in sheltercd spots on the surface of the ground, or they may be nerely placed in a pile on the ground with a sliglit covering of leaves or straw. A special point to be guarded against in stratification is alternate freezing and thawing. Seeds receiving this trentment should be planted innediately upon being removed from stratification and before signs of growth appear. A few hours' exposure to wiud and sun may prove disastrous. 

PLATE II
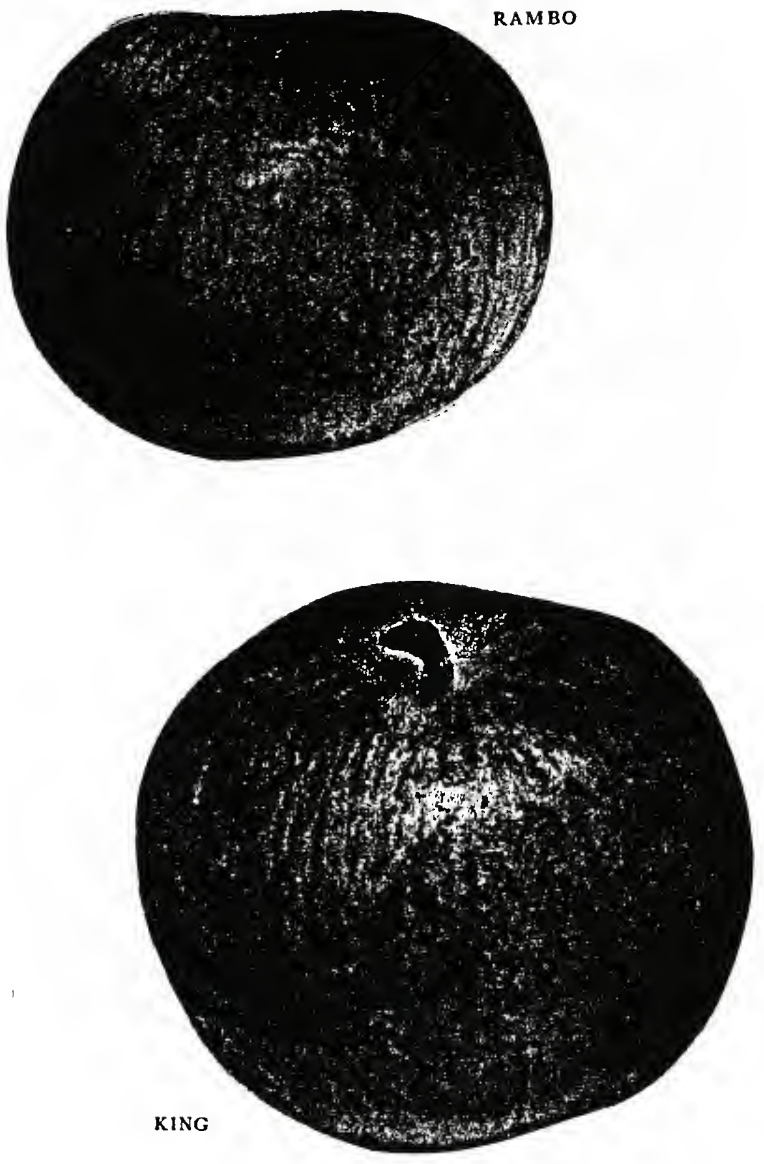
Chapter III.

\section{SFITTING TRIESS.}

Trees are like children: In the beginning they give us a great deal of trouble and worry, but in the end a'e are proud of them.-Farmet Vincent.

Most planters make the mistake of setting their trees too closely together. It seemsito them no better tlian an extravagant waste of grombl to set little spindling trees so many feet apart, and it requires some inngination to think that the trees will ever completely occnpy the gronnd. As the man stancls off to survey lis ncwly-set orchard, it actmally seems as if there were nothing there! But if he could see that same orcluaril a few years hence, in lis mind's cye, he wonld surely see the great wisdon of giving each tree plenty of "elbow roon.."

Here is a table of planting distances whicl is safe to follow :

\footnotetext{
Almounls, . . . . 16 to 20 fect each way. Apples, . . . 35 to ful fect calcll was. Apricuts, . . . . 19 to 20 fect call way. Cherries, sweet, . 20 to 25 fect eacli way. Chetrics, sour, . . 16 to 18 fect eacls way. Chestunts, Paragon, A bout $30 \mathrm{fcct}$ cach way. Orauges, . . . 25 to 35 feet cach way. (1)warl kinds less). Peaclies. . . . 18 to 20 fect cach way. Pcars, stasslard, . 20 to 25 fect cacll way. Pears, dwarf, . . . $12 \mathrm{ft}$. to $1 \mathrm{rerl}$ cach way.

Pecaus, . . . 35 to 40 feet each way. Pluns, ..... 18 to 20 feet each way. Quinces,. . . . 12 feet each way.
} 
After the tree planter has succeeded in conquering the temptation to crowl his trees too closely together, he is often bitten by another temptation-the "filler" illea. An orchard "filler," as the word is nsually nuterstool, is a sulall-growing, short-lived trec,something which begins to bear fruit quickly, and which can be cut out after a few years when it begins to crowd the main trees. In theory the idea seems all right, but in actinal practise it cloes not of ten work ont entirely satisfactorily. Usually the fillers are not cut out soon enougl. It requires a good deal of pluck to cliop down a nice tree, even if it is "only a filler." The11, again, there's often trouble because the transients and the permancuts require different treatunent. For instance, the full-strength Bordeanx mixture would be all right for apple trees but too strong for peach or Japanese plum trees; and the latter might require later or shallower cultivation than the nonproducing apples.

The effect of distance between apple trees set about 1880 , was recently studied in its relation to yield. The following fonr-year averages were found:

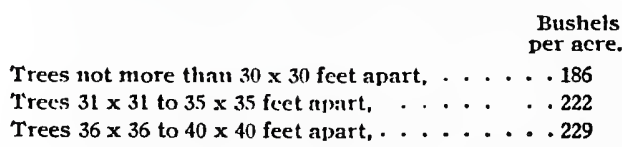

Which goes to show that it does not pay to set trees too closely together.

The first thing to do in setting an orchard, is to lay ont and mark the onter sides of the field, accurately,-these being the base lines from which to 
work staking operations. Square the corners by sighting along a steel square laid on three stakes, the widdle stike being exactly on a corner. When the four corncrs are thus established, measure and stake wliere the ontside trees arc to go, on two opposite sicles of the siuare. But do not have these treeplaces nearer than twenty feet to the onter limits of orchard field (if there are shitle or windbreitk trees on the orchard line, make the distance at least forty feet). Renember that when you come to work the orchard, you will want plenty of roon of the onter edges, - to turn the tean, the harrow, or the wagon.

The square system of planting is easiest and therefore most commonly used. Trees should be set exactly straight, becanse this adis to the looks of the orchard and facilitates cultivation. Here is an excellent method of staking and planting: Begin by using a small rope or wire, stretching this from one base-line to the correspondling stake on the opposite sicle; then put in smill pegs along its entire length, the distance apart at which it is intended to plant the trees. After the whole orchard has been so laid out, take a double-staking board llaving three V-shaped notclies in it. This board may be about four feet long and perhatps four inches wide; any thickness desired. Start at the first peg and place board so that the stake fits in the centre notch, - then renove this stake and put it in the notch made at one end of the board, and put ainother stake in the notch in the opposite end of the board; and continue until the whole orchard is donble-staked in this way. A hole can now be dug between eacli two stakes. To to the planting the 
staking-boarl is again bronght into requisition and placed over the liole, so that the two stakes fit into the notches at the encl. Then the young tree is held so that its trunk fits into the centre notch,- - just where the single stake stood bcfore the double-staking took place. In either double-staking or planting always work from one encl of the row to the other, and always keep the centre notch of the hoarl facing away

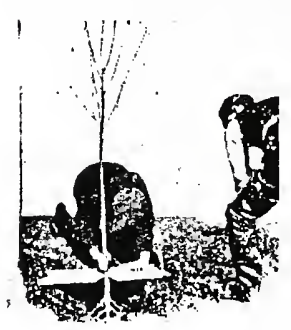

STAKINR-ITOARI IN ITSF from your. If one is careful in performing this work it is sure to turn ont well. 'This somuls like a complicated operation, perluaps ; but really it is very simple and easy in practise. The picture plainly shows low the board is made and nsed, and it is hardly necessary to add that eacli tree is to be lield exactly in place in the notcli mitil most of and firmed securely in place.

Number of trees required for an acre:

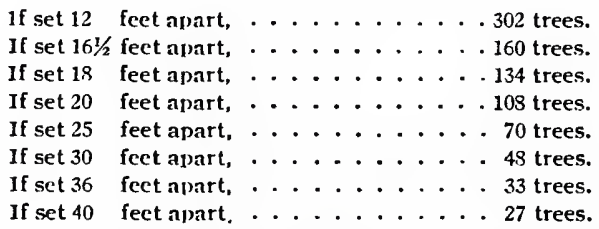

(Notr: 'The foregoing figures are based on the square system of planting. If the trinngular metlon is nsed, alout one-eighth more trees can be set on encls acre.) 
The one objection to planting in squares, says Lowell B. Judson, Idiho lixperiment Station, is that it does not cover the gromul uniformly with trees; for instince, $\Lambda$ is farther from $D$, and $B$ from $C$, thim $\Lambda$ from $B$ or $C$, or $B$ from $D$ or $\Lambda,-$ making a waste of s........ space in the minclue of the square. (See illustration.) 'This is sometimes ntilized by plinting a tree there, such as a peach or some quick-bearing or short-liverl tree, temporarily to occupy the gromul ; but this results in crowling, in a very few years.

'The lost sclieme for getting the maximunn number of trees at a given distance apart on the limd, is the hexigon or triangle system (sometimes called the septuple system), which makes every tree exactly the sane distance from each of its neighbors. The accompanying diagram shows the arrangement, and the dotted lines make plain the triangles and hexagons. If eaclı tree is joined to each of its neighbors by a straight line, a netwo:k of triangles will be formed, and enclı gromp of six triangles arouml eacli tree forms a liexagon with a tree in the centre. 'There are several ways of laying out an orcharil on this plan, the most expeditions being to use a wire. 'The end stakes of the second row are most eisily found by means of a wire triangle, eacli side of which is as long as the desired distance between trees.

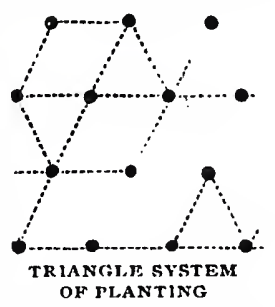

'llomas Meehan gives the following directions for planting fruit trees received from a nursery, and he 
has covered all the points so well that I can not do better than to quote his methou:

"Quickly unpack stock npon arrival; shake out packing material; dip the roots in liquid nuncl. In

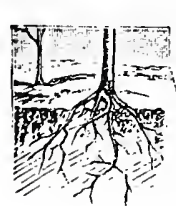
case stock cammot be immediately set ont, prepare a place where it can be tennporarily planted, taking care to cover. roots thoronglily, working the soil in anong the filures. 1)ig generous lioles, provicle goorl soil to fill TREESET Too thein; don't bend roots; niGH cleanly cut off severely brnised or broken roots, and never let them dry. 1)ip them in mud, place in liole, throw good soil in liole, tightly ramming it around roots after eacl slovelful. I.eave no air-pockets. After

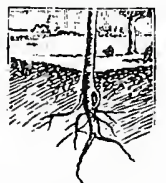

TOO LOW AND IN A HOLLOW

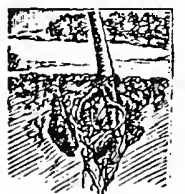

ROOTS HADEX ISUNCIISH, TOGETHER lole is filled, cover top of ground thick: ly with good, well-rotted stable manure as fir as roots extencl."

I,ook ont for crown and root galls. Burn all such trees. Crown gall is a comnon disease in many murseries and it attacks all kinuls of fruit trees. It is the worst kincl of folly to pliust a tree whicl lias a trace of this disease, for not only is the tree pretty sure to die before it comes into full bearing but the infection maly be spread to all parts of the orcharcl. If galls (knotty, buncliy swellings) are fonnd at the

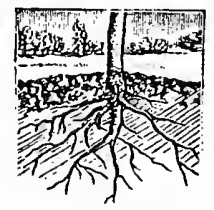

TREE SET PROIERLY 
base of tree trunk, the tronble is probably the fungous disease called crown gall; if found on the roots of apple trees, an insect called the woolly aphis is to blame.

\section{USEFUI, SIDE SHOO'TS.}

A tree out of place is a nuisance; in its place it is a blessing.

Do not let mannre conte in direct contact with the roots of young trees. Apply mantre as a mulch.

An assistant is very helpful wlien setting trces. 'Two men, or a man and a hoy, can work torsether to good advantage.

lietter not dig holes much in advance of the tree-setting. Soil dries out quickly, and roots need moist earth around thenl.

Thrifty young trees are more apt to live than the larger, older ones. Yonng roots are smaller, and more apt to be all taken up in transplanting.

nlow dcep shonld trecs be set in the ground? A little deeper than they were set when growing in the nursery. Deep enongh so that the joint between stock and scion is covered.

For neasuring purposes a wire is better than a rope or cord, becanse it will not stretch. Stick a bit of solder on the wire, exactly where each tree is to come. String or bits of cloth tied on, are apt to slip.

As the tree-setting progresses, it is a good plan often to "sight" the rows across from side to side, both ways, to make sure that everything is exactly straight. The eye is an excellent detector of unsnspectesl crooks in rows.

In cxposed situntions or in windy localities, it is a good plan to incline the newly-sct tree slightly toward the northwest or whichercr point of the compass the strong winds come from. The trees will straighten as they grow.

One or two old blankets will cone in handy when setting trees. As fast as an armf itul of trees is dug from the heeling-in place, wrap the roots in a blanket intil all are planted. Don't let the roots lie aronncl in sun and wind, unprotected. 
The safest way when lmying fruit trees is to dip them in the line-sulphur mixture hefore setting then or heeling them in. Do this as a matter of precaution against the San Jose scale louse. The best way to fight this pest is to fight it from the very beginning.

Farm Joirnal says: "The other day we saw Peter Tumbledown on his way hone witl a load of loose fruit trees from a local nursery. The wind was blowing, the sun was hot, the trees were unprotected by even a blanket. Next ycar Peter will be finding fanlt with the nurseryman because the trees are no good."

How not to plant trees: " Dig a hole, do not tronble about $j$ deptlı nor the space that will be recuired for the roots. If the soil consists of brickbats, it will clo! Select a tree that is sure to be too big for $i$ ts place itu a short time. You can then cut off its branches and make it look like a real work of art, such as a clo(lics-prop or a gibbet. J'lant the trees as thickly as possible, and forget to thin tlicul out. Yout will then proluce an innuccliate effect, and yon wiil have the satisfaction of witnessing a fight-and appreciating a struggle for existence. Ilaring planted your tree, stake it in such a way that the stem may be suapped off; this will give the wind something to do. Never think of removing the stake or loosening its ties-that wonld involve too much trouble. Avaid placing any guard around the newlyplanted trees. In this way you will provide fodder for your neighbor's horse, which will graze contentedly on the bark; and you will provicle healthful anusement for the boys, who will playfully score the bark with their knives." My good wife Harrict clipped these rules from an old publication, and she says that they are full of "contrary nsefulness." 



\section{PLATE III}

\section{BEN DAVIS}

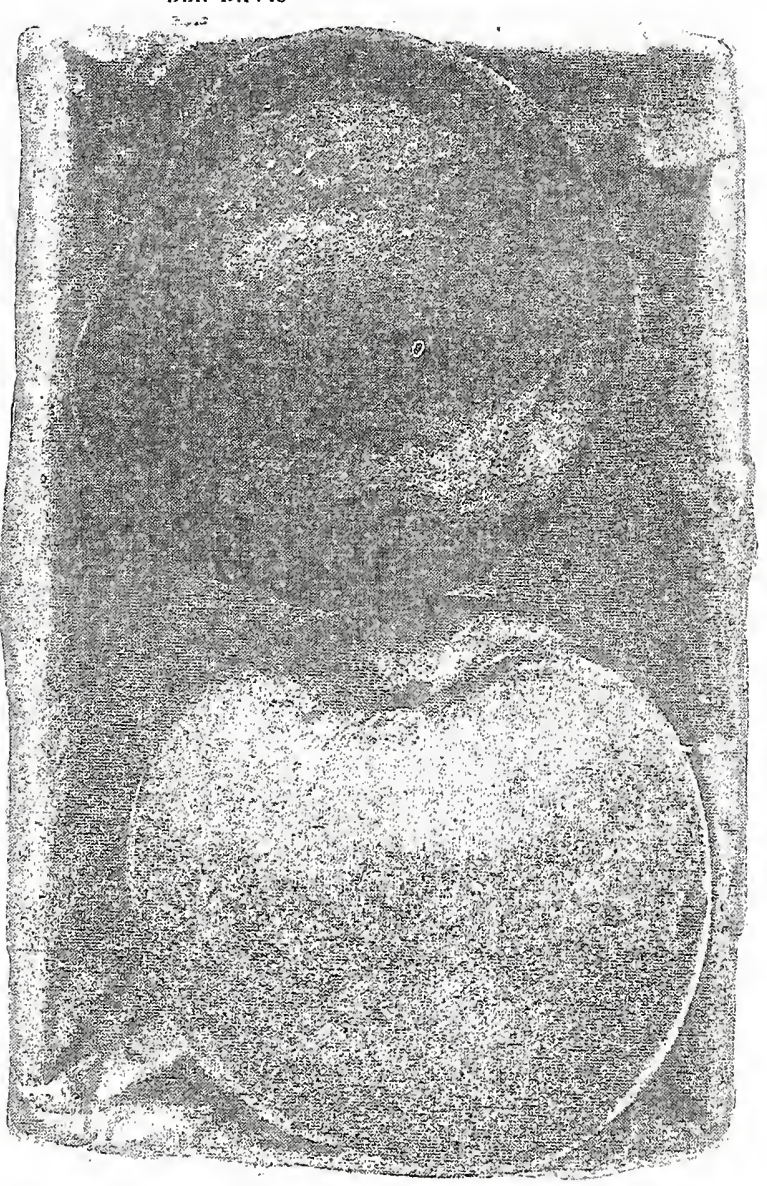

RHODE ISLAND GREENING 


\section{Chapter iv.}

\section{PRUNING $\triangle N I)$ I:ARI,Y CARI: OI NLIVI,Y-SIET 'IRIELS.}

\section{Take cave of your orihmal and your orchard zeill lake cate of you.- IIarrict.}

The newly-set tree must quickly be prmmer. As it stool in the nursery row there was approximately a balince between the top and the roots, the latter being just about enough, muler the conditions of that soil, to supply what moisture and nourishment the leaves and branclies neederl. livinlently if half of the roots were sululenly removed this efuilibrimu would be destroyeal, anul each leaf wonld show its distress at the decreaserl sip pressure, by wilting, and the weiker ones worla prolibly die.

Now, that is essentially the conclition of the nursery tree ; no n1atter how citrefully it was ang, miny of its fine feeding roots are sure to have broken off, or have dried up; and nutil it cin re-establish its relations with the soil, and put ont new roots to take the place of those destroyerl, it is totilly muble to support amb nonrish the original amonnt of top, the finc ronthairs, which appear like fruz near the tips of the swaller roots, and ilo most of the absorbing for the roots, dry ont almost instantly on exposure to air, an11 are practicilly all destroyed in transplanting. It takes some time to frm these anew, ant if the whole top is left to "leaf ont" "luring the process, the rupid 
evaporation fron so many points will result in disastrons drying of the whole tree.

That can be avoided by cntting back the top to correspond with the roots, thus redncing evaporation to the point where they can supply the loss. In the case of the yearling whip withont sicle branches, it is sufficient to cut it off at the height at which it is intended the lender shall start ont - say about two or

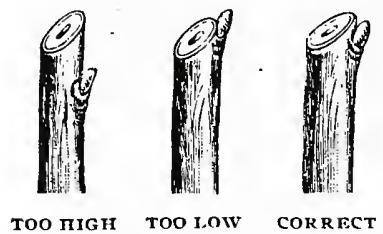

CUTTING "TO" A BUD three feet above gromul. Always cut to a bud, making a sloping cut which leaves not more than a quarter of an inch projecting beyond the bud. During the summer all the buls along the side will develop branclies; all the lower ones and those not intended to form the main framework of the tree must be pinclied off, otherwise the lower branches maty make a shrub of your tree. $A$ in to throw all the strength of the growth into the required main branclies.

Branclied, or two-year-old trees, rechine a different style of pruning after being set. The lower limbs have generally been cut off by the nurserymen before the tree reaches the planter, so the lieight of the "head" is, in a sense, already fixed. What remains to be done is to choose three, fonr or five limbs to form the future framework of the tree. These should come out from the trunk in different directions, distributed as evenly as possible; and, if feasible, no. 
two branclies shonld cone ont exactly opposite each other, or a weak crotch will be formed which may break and split at some critical time. Sererely cnt back the cliosen limbs and remove all other linils. liach of the remaining limbs should now be abont six or eight inches long; usmally with the terminal bul pointing outa'ard on eacls. (1f the variety's hathit of growth is naturally very sprealing it is sometimes best to correct this tendency, by cutting to terminal burls which point inward.)

liorms OF IIEADS. - The

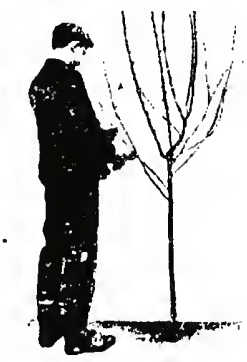

REAIUY TO FRUNE; NFWLY-SET AI'ILE TREE apple, peach, plum, quince, sour cherry, ancl similar

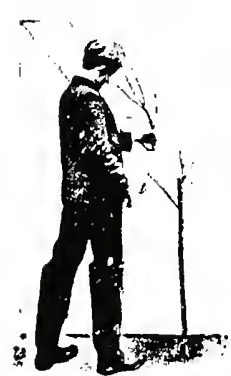

SAME AIPIE TREE TRUNEDIN OIEN CENTRE, STANDAR FORM trees, frequently seem best allipted to the open-entre, sprealing, stiundarcl form. In sucli cases a central leading sloot is not needed or wanted. 'This matter is nure or less a matter of clioice. Sonte folks prefer a "leatler," others do not.

'lite sweet clierry, pear, etc., often seem best snited to the upright, central-leader form. In such instances it is nsual to have this main sloot a little longer thitu tlie sicle branches, - with its terminal busl pointing toward the direction of prevailing lighlı winds. 
l'RUNING l'IinCII 'l RIits. - It is customity to prune newly-set peach trees differently from most other trees.

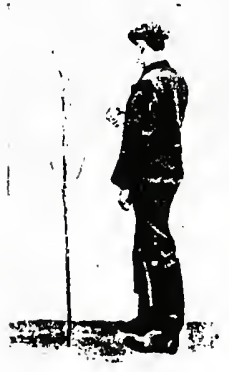

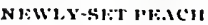
TRLF, HIITRI: IRUNINC:

Whether the nursery tree is a branchless whip, or a well-branched tree, the cntive top should be cut off at the point where a new head is wantel. If any branclies remain below that point, those, also, are cut off,-not too closely, however ; 'tis usually better to leave stubs abont an incin in length, so as not to injure the remaining bud. Some peach growers cut off their trees at a miform height of about one and one-half feet; others prefer a height of two, or two and one-half, or even three feet. The decision dapends somewhat on the size of the trees, and the grower's personal preference; but there is no donbt that the lowest possible head, consistent with future cultivation, is most desirable. 'Iwo feet, or two feet and a quarter, is perluaps a liappy medium.

'THE "STRINGFELLOW METHoD." $-\Lambda$ very severe kind of root and top pruning, known as the Stringfellow method, is sometimes alvocated. The clinef atlvantage claimed is that the roots grow straighter downward than with ordinary trees, giving greater

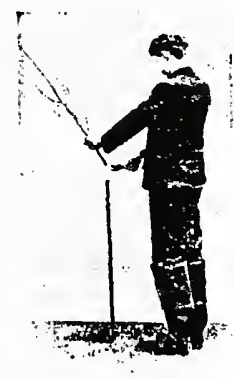

SAMFIEACI TRFF: AFTER IRUNING 
security agilinst aronglit and high winds. The lalbor of setting is also mucl redncel, as a smiall liole will

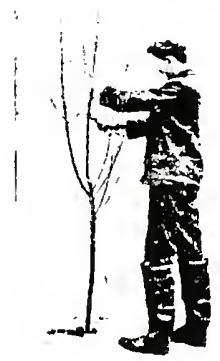

NEWLY-SITT PJAR TRIEE, HEFOR 1:

TRUNING accommolate the stubbed roots, incl it is an easy matter to pack the earth around them. 'line tree is, in fact, reduced to a cutting; but cuttings of wooly plants are not apt to do especially well ontof-doors in this country. 'lo grow a cutting successfully the soil slonld be as warm or warmer than (lie air, to stimulate the formation of roots before the top starts to grow; if the latter starts first, the demand for sap, and rapiıl evaporation, will quickly exhiust the juices of the stem, and it dies. In the sancly soils of 'lexis, in which Mr. Stringfellow planted his trees, he had a natural propigating bed, a very warm soil and all the conditions to make cnttings do well. I will admit that some orchardists in other states hitve hiul more or less success with this nethod; but, personally, I prefer to plant my trees in the good old waywith all the roots on them possible. 'Tinn says that he can't see any wislon in cutting off a tree's entire stoniacl.

RECORD OF VARIETIES.-The best way to establish silch a record

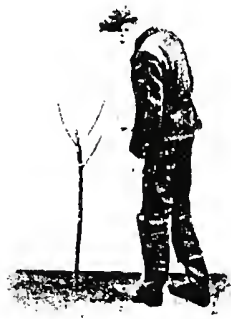

SAME TPAK TREE PRUNED. CENTRALLEA JFE FURM 
is to make at detailed plan of the orchard as advised in Chapter I. The map should show the proper name, place and age of each tree. The next best way is to label the trees. Whatever you do, don't trust to memory.

A good tree lahel: Procure a thin piece of sheet zinc, six inches wicle, from which cut strips crosswise three-quarters of an inch wide at one end, and tapering to one-eighth inch at the other ent. Odd pieces of old zinc, stove boards, etc., may thus be ntilized. After heing cut, the pieces should be put in vinegar to allow them to corrole, after which an ordinary lead pencil will complete the husiness. 'Jither or both silles can be written upon. And the writing will list BALOWIN-MAR. 1906 for years, too, so tliat "lie who runs may read"; as linnclreds of labels in this vicinity can testify. The diagram explinins the iclea. Simply wrap the small ent of label loosely around a liub of the tree - rather than aromul the trumk. As the limbl, grows, loosen the lathel somewhat, or change it to a smaller limb. On the reverse sicle of the label it might be well to write the name of the agent or nurseryman who furnished the tree; then, litter, if the variety proves mintrue to name, yon will know whom to blanle.

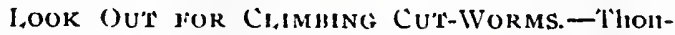
samls of newly-set fruit trees die every spring" unaccoun tibly." Usually, too, the nurseryman who furnished the stock is blamed; when, in reality, the tronble is often a climbing cnt-worm that comes, like a thief in the night, to feast on the swelling, luscious bucls. And, when daylight appears, he crawls down 
and hicles in the soil or muler a stick. Oh, he's a sly fellow 1

This slightly-redlucel picture slows how this whitish pest looks when he's at work. Several inethods of con1bating cut-worms have been inventer, but one of the best ways is to fence them ont. Irig. I gives

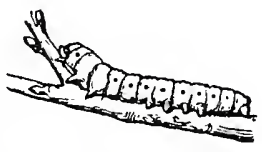
the idea. Cut some stiff tar-paper into sirips abont nine inclies long and two or three inclies wide. I'nt a strip around a tree trunk, tightly lap the elges an inch or more, and push the lower half of the circle into the soil-to anclior it and to prevent worms from easily burrowing bencall. It tiskes but a sloort time - and only a few cents- duns to protect several hiniared newly-set trees. All that is necessiry is to have the paperat least an incli and onelialf away from all parts of the tree; to have the elgres lipperl tightly ; and to make sure that no worms are hid in the soil between the paper and the trec. Any kind of stiff paper, or wool veneer, or tin, will do; I pre-

fer tar-paper because it is lasting and cheap.

FIG. I An orchard thins protected is safe for many weeksuntil cut-worm dinger is mostly over. Just why the worms do not "climbl over the fence," is at puzz.le. J3ut they very rarely do. These worms are less tromblesome on heary soils than on light soils. 'lhey scem to prefer sandy ground, in which they can more easily hide and propagate.

DAINGER OH I'REMATURE I'RUIT-BEARING.-The act of bearing fruit is sure to stunt the growth of 
very young trees. It pays to pick off the blossoms from all very young frnit trees. Two neiglıbors tried this in two similar cherry orchards. One man had the clitdren pick off all blossoms eacli yeatr; the other min didn't. At the enul of five years the first man's trees were nearly twice as large as the second man's. ( $\Lambda$ ge of trees, care and soil, were the same, otherwise.)

\section{IIIN'TS IOUR TItI: IIIIIDIUUI.}

Don't forset to visit the young trees oftcn and rmb off all shoots which are not needed in the formation of the new head.

1)u't overloxk this fact: Success or failure with an orchard after it lias been planted depends npon the care given the young trees for the first few years.

Many a nice little tree has heen ruined because its owner forgot to remove the wire label that the surseryman put there. Better look after those wires right away.

Ion't neslect, after the first heavy rain in Mas, to throw two forkfuls of strawy manure around each newly-planted tree, - to keep the moisture in ante to insure a grood start.

If the focation is a windy or nupirotected one, flon't forget in late summer to stake the young trees. Int nse cloth bands about the bark-not cord or wire, which would probably cliafe and injure the tencler trunks.

If the gronncl around young fruit trees is not kept constantly cultivated, the trees should he heavily mulched all summer. Straw or strawy manure is a gool mulch. Newly-set trees have no deptli of root and they dry ont very rapidly.

Jom't, as a rule, when proning newly-set trees, cut "to" terminal buts which point ima'ard. Why? Ilcenuse, if you do, the new tol" shoots will he ant to grow in the clirection the buds point, thus cansing crossed limbs in the ccutre of the new treehead.

The advantages of low-heacled trees, says Prof. Bailey, may be mentioned as follows: (ireater ease in picking, thinning. pruning and spraying, and less clanuge to trees and fruit from winds. Some growers object to low-headed trees on account of the greater clifficulty of cultivating around them, but with proper pruning low-healed trees elevelop ascending branches which permit proper working with a team. 



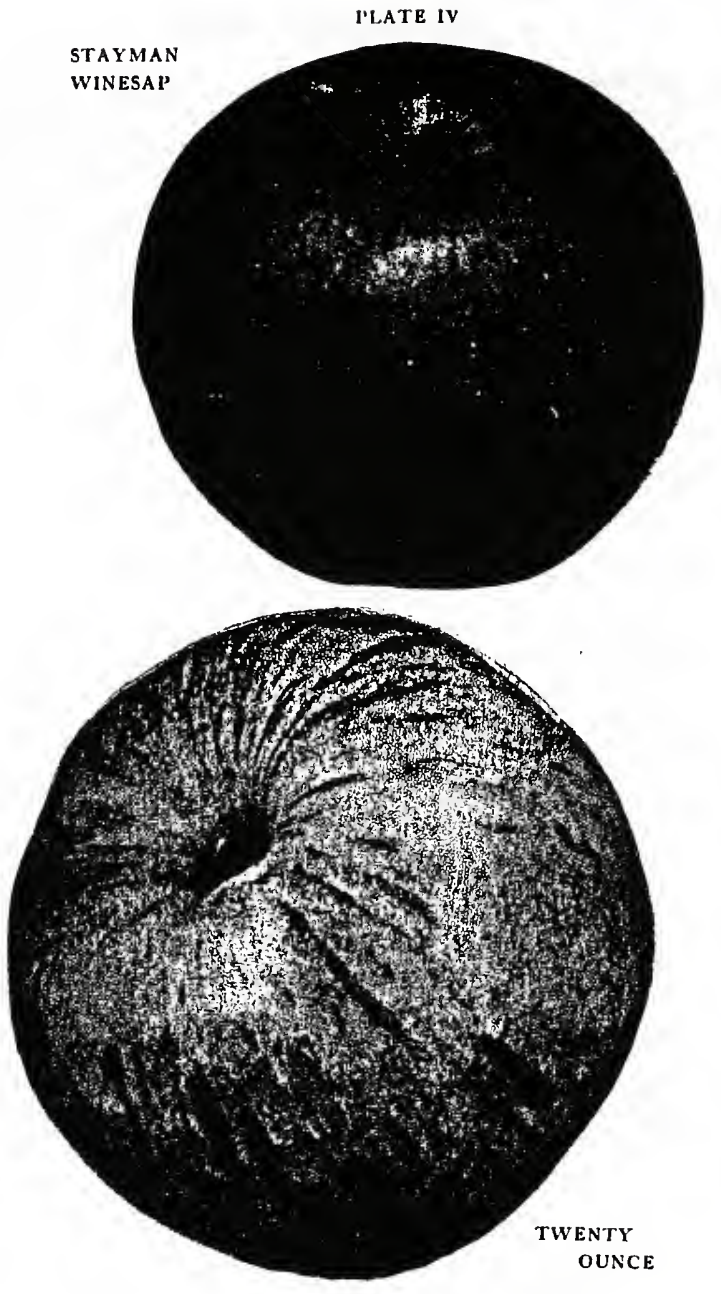




\section{CHAPTER V.}

\section{ATIER I'RUNING.}

The ideal prwning consists not in checking gronth, but in directing it.

Before tonching sitw or knife to a tree, the orchardist shonld hitve well in mind what he onght to accomplish by the work. Among the following are the cliief o!jjects songlit:

1. 'To restore the balance between top and roots at time of setting ont (as told in Cliapter IV).

2. 'Io make the top open-centred, regulate the number of limbs contposing $i t$, fix $i t$ at the proper lieight from the groninl, and do away with weak crotclies.

3. In older trees, to renove crossed branclies, and thin them ont to adıit sunlight and thus facilitate spraying, ripening, etc.

4. 'lo incluce the proluction of fruit ratleer tlials wesel, allul vice versa; in other worls, to correct sliy bearing ancl overbearing.

5. 'lo keep lower limbs ont of the way of cultivation, and npper ones from growing ont of easy reach

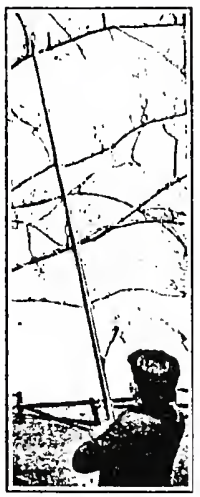
of spritying, picking, etc.

6. To cliange biennial to annual bearing ; in other words, to break a tree of the "off year" habit. 
7. To correct a too compact or a too spreatling growth of top.

The "idleal" pruning, says IV. N. IIutt, would consist in renoving not branches but buds; not in

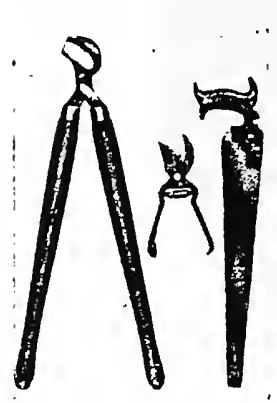

TIRER TRIINING TOOLS MOST USI:1) cliecking growth but in clirecting it. It is less shock to the tree to pincli off bucls here and there, than a few years later to saw off large, misplaced limbs. From the silp is manufactured botlı wool and fruit; it is better, therefore, to direct the energy of the mature tree toward growing fruit which goes to the cellar and market, than in making wood which goes to the brush pile. It is largely a question of the proper direction of the energies of the tree. Many trees mity be so formed and shapel when young that in later years prining need be only slight, and it will never be necessary to cut ont large limbs. Few of ns, however, are able to live quite np to this illeal nethod, and so we often resort to the saw and shears.

WHEN TO PRUNE.-The time that pruning should be done is determined by the purpose such pruning is intended to serve. Pruning of trees to enconrage fruitfulness should be clone in sumumer when the trees are in active growth, preferably in June. I'runing for wood growth, on the other hamd, shonld be

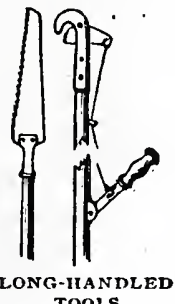
TOOLS 
done when the trees are dormant. The best time is in the spring before the buts start.

Pruning should 11ot, as a rule, be done in winter time. When a wound is made in winter the delicate cambinu bark layer is exposell to rougl winds and low temperatures and is killed back for some distance between the bark and the wool. Iivery day of zero weatler increases the tronble, and, in spring when growth starts, instead of the cambinm starting at the cut to lieal over the womnd, it has to start consiclerably below. Frostbitten wonnds are slow to heal.

'Tlousands of fruit-growers invariably prone tlieir trees in early spring, - not fron any wellconsiclererl convictions as to the effect on the trees, but 111erely because it is

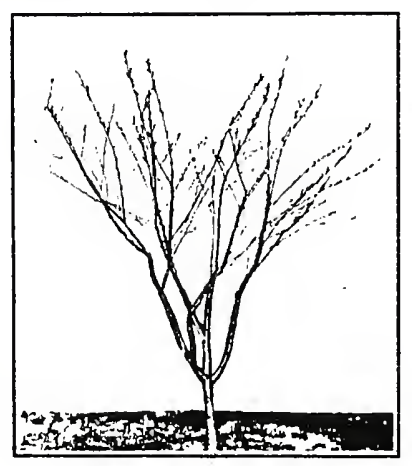

THREE-YEAR-OLI PEACH TREE, AFTER BEING PRUNED the slack season of the year and therefore most convenient for pruning operitions. 'lhese gool folks should ask thenselves this question : " Do I most need and want wood growth in my orchard, or fruit growtl ? ",

If the orchard has been recently set, or if it is old and run-down, wool growth may be more desirable 
for awhile. But if there is alrealy sufficient wool growth, why prune at a time that forces more of it? Stop and think a bit.

GeNeral RULAS IOR I'RUNING. - Never cut away more woor thin is necessiry to obtain the end in view. lirr on the sicle of culting too little rather than too much, for if too much is tiken off it can not be replaced in muny years. Large crops of fruit can not be grown on trees with a few exposed branclies. Cut ont all dead wood as soon as it is discoverel. If two branches rub together so as to injure one another, the weaker shonld be cut awny. If one branch rests on the top of another, one should be removed. IIead back and thin ont the top rather than cut of the lower

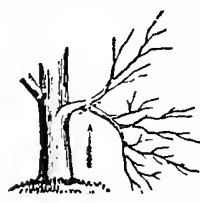

ric:. I

NINa: $A$

BRANCII

branches, so ats to bring the fruit as low as possible, on account of thinning, spraying, and harvesting. Never remove entire side branches if it can be avoided. If it must be clone, cut as shown in Figr. I; thus the tree is trinmed up for horse cnltivation withont sacrificing the whole of main linb.

$\Lambda$ il cuts slionld be left as smooth as possible; and all wounds more tlian onehalf inch in clianeter onght to be covered with a coat of thick linseerl oil paint,to keep ont diumpness and prevent rot while Nature is liealing the cut.

Never leave it stub. Cut close, yet not too close. (See Irig. II.)

Cut out suckers on a tree whenever your see thenl. $\Lambda$ lso, watch for and cut

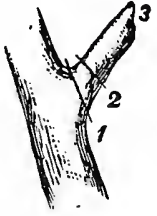

FIG. II CUT AT 3 OR 2 IS WRONG. No. 1, RIGHT 
off any suckers which nlay grow from base of trunk. Do this at any time.

When cutting off fair-size linbs, saw the unclerside of the limb alout one-thiral of the way througlı, or till the satw begins to pinclı, and then saw on top abont one-lialf incli from the undercut; and when sawed down almost to the nulercnt the limb

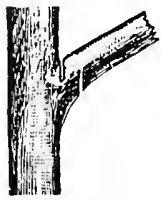
will break off and not peel lown the sicle of the tree.

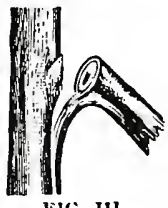

Fiti. III CUT NOT SO (See illustrations, Figs. III and IV.) Then continue the top cut so as to leave no stub.

Root-pruning is sometimes practised,

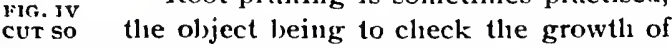
a vigorous tree (which is old enouglı to bear, but which refuses to (lo so), and thus favor the development of frnit buls. This operation is seldonn necessary, however, and few orchardists ever attempt it.

l'runing a neglected olil orchiril is often a puzzling jol). 'lo clo the work right, a vast amount of wood nunst conne off, and, consequently, the average prumer is likely to remove too mucl, thus doing nore harm than good. Ilere's a gool rule for sucli citses: Do the job in three installinents-one eacl year-and no installuent undnly MAKING THE lienvy.

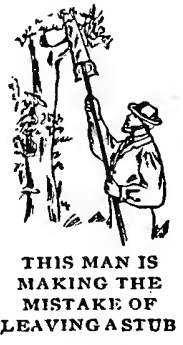

Keep all pruning tools sliarp. Prune annually but not lieavily. Never allow stock to prune your trees. Heavy pruning concluces to wood growth. 


\section{COTHINGS.}

Drastic pruning strikes at the vitality of the tree.

Never hurt the bark, bore lsoles, or drive nails in to trees.

Unpruned, uncultivated orchards are not money-makers. Bailey.

The orchard is not a profilable source of firewood, say's Prof.

A heavy pruning is alway's followed hy a heavy growth of silckers.

'lhe hatchet and the ax are not good pruning tools, says Farmer vincent.

'lhere is such a thing as having the head or centre of a tree

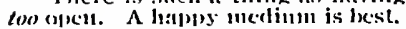

Special pruning directions for cach kind of tree will he fomul in the chapters devotcd to 'rlie Apple, 'The l'ear, 'The Cherry, etc.

Don't leave the pruning to ignorant or careless hired nen. Do it riglıt. The nuore the pruner knows, the better he can prume.

It is a common notion lluat the hranches gradually get higher from the sround as the lree continues to grow. the apparcut gain in height is cluc solely fo the inceresce in alianclet of the limbs, which soon hegin to erowel if sufficient space lats not been left hetween them. 'The centres of the lintss will always renain the same distance apart.

As regards the thiming out of the tops of the pear, apple, peach, and similar trees, no general rule can be given, as each tree presents a different problen. A thick growtl of new branches results in weak bearing shoots and sjurs. When cutting back limbs on learing trees the cut should be made just above a strong lateral, wherever possilule. The lentency of the sap will then he to flow iuto the lateral and thus prevent the forihation of the numerons branclies which nearly alway's result when a so-called stub-cut is made.

The orchardist should become well acquainted with the habit of growth of rlifferent varieties. A few kinds grow slowly and will not bear henvy pruming. Others are: erect growers; and some are surending. (bite can not expect entirely to gvercome such tentencies, but they may be corrected to a marked regree. 'the upright varictics may be sureal somewhat by pruning to outside laternls or lituls, and the spreading kinds may be contracled loy cutting to laterals or butls which have nu innenrd direction. And ly cutting back the vigorons growers each season, the limbs are made stocky, thus in great measure doing away with drooping brauches. 

PLATE $V$

BALDIVIN

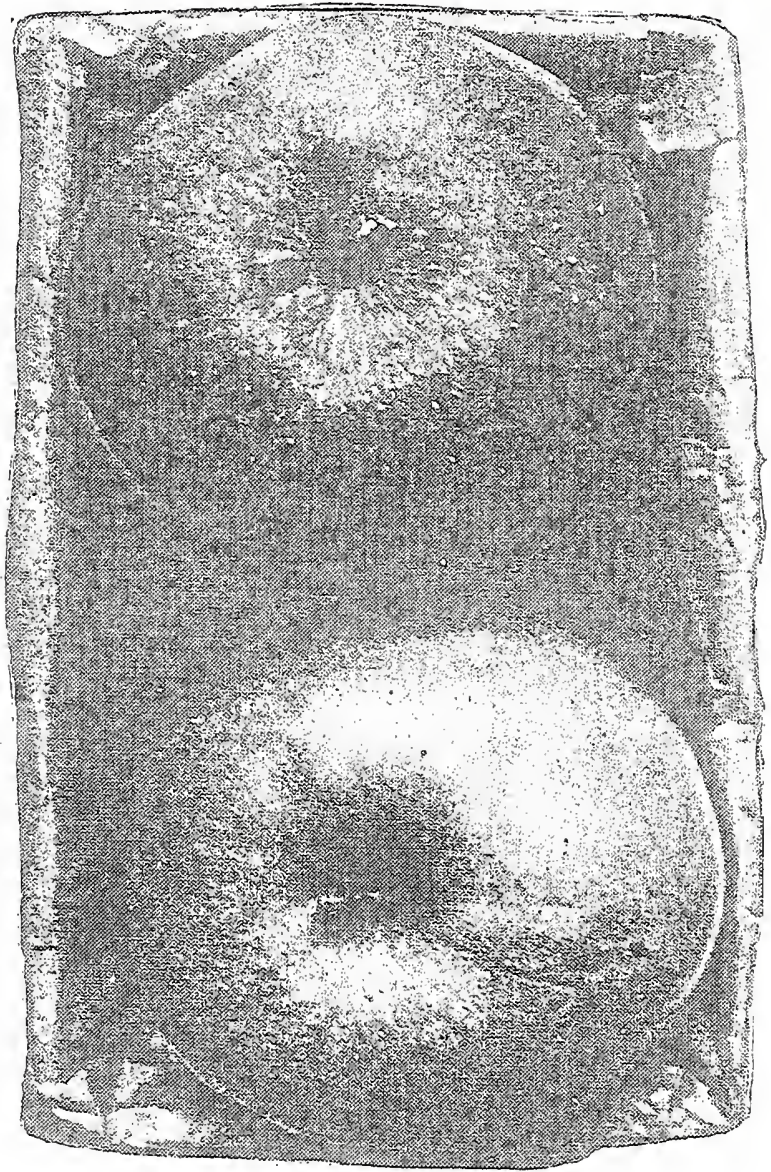

YELLOW NEWTOWN PIPPIN 


\section{Chapter Vi.}

CUJTIVATION. WERTILIZATION. TIIINNING.

If a man isn't willing to rumy and feed his orchard, he need"'t e.pect thoroughbred results. -'Tim.

'The offices of tillige are several. Among the more important ones are :

1. The setting free of plant food by increasing the chentical activities in the soil.

2. 'The soil is mille finer and lience presents greater surfaces to the ronts, thus increasing the areat from which the roots caln alsorb nutriment.

3. 'The surface of the soil is kept in such combition that it inmediately absorbs all the rain that falls during the summer, iwleen it is apt to be dry. I,ittle is lost by surface drainage.

4. Moisture is conserved thereby. Where the surface remains nulisturbed for weeks the soil becomes packet, so that the moisture from below reaclily passes to the surface and is evaporated, thins being lost to the growing crop. If the surfice is kept light and loose by tillage, so that the cipillarity is broken, but little of the soil moisture contes to the surface and evaporation is not so great. In this way nearly all the moisture remains in the soil, where it can be used by the roots.

5. THorough tillage has a tendency to canse deeper rooting of the roots. The surface of the soil is mate drier by tillige luring the early part of the season than it woull otherwise be ; hence the roots go where the soil is moist. The alvantage of deep rooting during dronght is obvions.

6. Weeds and grass are kept ont. 
A Cultivation of Young 'lrees.-John A. Warler, in his book abont apples, says: "If the ground, which has been appropriated to the orchard, be also occupied as farming land, as is nsually clone for a few years after planting, while the trees are small, it should be exclusively devoted to hoed crops; by which is meant those that require constant cultivation and stirring of the soil." That's the illea, exactly. While the trees are coning into bearing, and before they liave need of all the land, we can kill two birls witlı one stone$i$. $e$., give tillage to the trees and cultivation to a

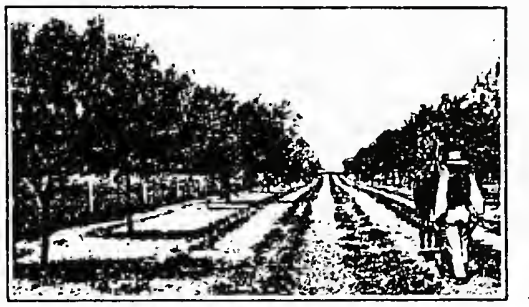

STRAWBERRIES IN YOUNG PEACII ORCHARD

marketable crop, all at one operation. We can, for several years, grow strawberries in rows, or potatoes, or some other cultivated crop. What we ought not to do, is to grow hay or any of the grain crops; nor should we let the land grow up to weeds. If we do not care to grow any crop on the land except trees (and some large orcliardists prefer this method), we should plow the gromel in early spring, and then harrow it regularly every two weeks until about August first,-at which time some "cover crop" is sown. (See Chapter IX.) 
CULTIVA'TION OF BEARING 'TREis. - It rately pays to attempt the growing of any "side " crop in an old, bearing orchard. The tree roots need-and occupyall the ground. Plow the orchiard just as soon as the soil is dry enongh in the spring. lionr inclies deep is abont right. One year plow "np" to the tree rows; the next year plow "away." Always plow in the sane general direction. Iincleavor to keep the surface about level during the growing season. Harrow the gronnd regnlarly and often. Stop cultivation about August first-later if season is dry,

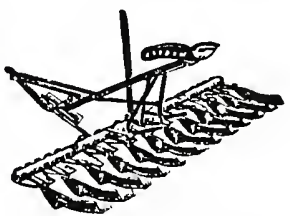

TIIE ACME IS A GOON ORCIIARD IIARROW earlier if season is wet. Seed down to some cover crop.

IALL-PLOWING OF ORCHARDS.-Some growers advocate a second plowing, to take place when regular cultivation ceases. They say: "llow up to the trees so as to facilitate drainage during fall and winter; this rilging-up also helps to protect the roots from cold." In some soils and climates the idlea is perlaps somud; on properly-drained gromd not too far north, it seens unnecessury. After $\Lambda$ ugust plowing, the harrow and the cover crop shonld innmediately follow, of conrse.

Sunstitute For Cultivation. - The "mulch system" lias its advocates, and its fanlts and advantages. Its main fanlts are: It furnishes a harloring place for mice and insects; it does not stinnlate tree growth, if growth is wanted; it favors fungous tronbles. Its main advantages are: Lessened labor (which is somewhat offset by the necessity of mowing grass and weeds which may push through the mulch); 
lessened woor growth (which in some cases mignt be temporarily desirable).

IRRIGATION. - In regions of normal rainfall, artificial watering of orchards is seldom practised or necessary. Cnltivation, nuler normal conclitions, conserves sufficient moisture for the trees' needs. In Cillifornia and some other states, irrigation is desirable. liolks who need to practise this method slionld write to the U. S. Department of $\Lambda$ griculture, Washington, J). C., and ask for free Farmers' Bulletin No. 116, entitled, "Irrigation in linit Growing."

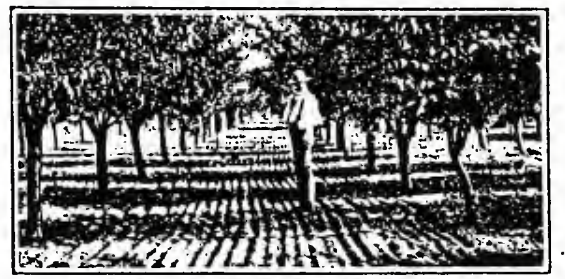

GOOD TILLAGE, TIIS

lirrtitization.-liruit trees need the sime ele-

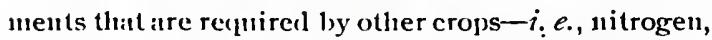
potash and plosploric acid. Nitrogen is particularly efficacions in promoting growtli. In fact, the anomint of growth and the color of foliage are reliable guides for the application of nitrogen. Leaves of gool size and dark color, and a wool growth of a foot or more on matnre trees in one seison, inclicate sufficient nitrogen.

Nitrogen is nsually most easily, advantageonsly and cheaply applienl in the form of legme cover crops (Cliapter IX). I'rof. Bailey, of Cornell, says : "In 
CULTIVATION, FERTILIZATION, THINNING $\mathbf{5 5}$

orchards which are thoronghly tilled, the use of birn n1anures (which con tain considerable nitrogen), slonld generally be disconraged. Use tillage and late green crops to snpply the nitrogen,-except perlitps for a season or two when an attempt is miking to rejuvenite a neglecterl orchinrl." One of the main objections to stable mannre is thit it is apt tocause trees to grow toolite in the fall.

l'otash is generally the most importimt element to le :1\}plient arectly tourcliarıls, piarticularly after the trees have reached hearing age. The aviilable store of potasli in the soil is mucli increased by the thorough tillige which has alreatly been recommended,

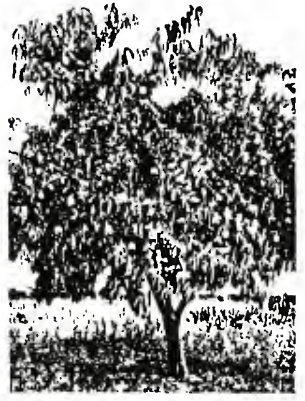

IIACIISA WII, TIINNIED.

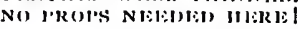

but in hearing orcharrls it slonla also be snpplied every year in some commercial form. One of the hest sources of potash for orchirits is mleacherl harrl-wool ashes. It gives fruit a high color. lorty or fifty busliels to the acre is a gool tressing.

Minriate of potash is perliajs the best anel most reliable form in which to secure potash at the present time, says Cornell Bulletin No. 72. Commercial simples generally contain abont fifty per cent. of actual potasl. Kainit or Germin potaslı silts is a numriate of potisl continining alont twelve per cent. of potasl. $\Lambda$ apple orchiral in full bearing and npon loose soil may receive as high as 1000 pommls of numrate of potash per acre, but a normal and economical 
application is from 500 to 700 ponnds. Sulphate of potash is also thought to be a gool form in which to buy potash. The commercial article will analyze fifty per cent. or less of acturil potasl.

Plıosphoric acid may be obtained in the form of a higlt-grade plain superphosphate (dissolved. Sontl Carolina rock), in bone compounds, and 'l'homas slag. The plain snperplosphate contains abont sixteen or eiglıteen per cent. of phosplioric acid, and 300 to 500 pounds per acre is a liberal and very nseful dressing for bearing orchards. The bone fertilizers are always valunable. Those which are nutreated give up their phosphoric aciul slowly, minless they are very finely grounl. 1)issolverl bone gives more immediate results. 'lhomas or basic slag hais given good results in miny tests, bnt it parts with its fertility very slowly. l'hosphoric acid is rather less important in fruit plantations than potash, although this order is reversed in general farming.

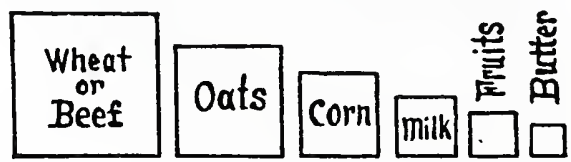

A little lesson in fertility: The size of these blocks shows the comfiarative quantities of soil fertility (nitrogen, potash, and phosphoric acid) removed from the farm by the selling of varions home-grown protucts. The growing of wheat or heef draws henviest on the soil; butter or fruits, lightest. Remen1ber, too, that most of the fertility removed by fruits is contained in the seels or the pit,- the 
fruits themselves are largely water. And that brings us to the important subject of

THINNING Iiruits. - If we can annually reduce the number of seerls (or pits) which a tree endeivors to grow, we remove a great vital drain upon the strength of peacnes Too THICK oN THIS both tree alul soil. We sive EIGIJEEN-INCH BRANCI fertilizer, and we sive tree vitality. Incidentally, we accomplish equally important secondary results. By removing, say, one-half of the baby fruit on a tree, the remainder is enibled to grow to larger and more profitable size; and next season the tree, not laving exlinusted itself the previons year, is in proper condition to be:ir anotler full crop. In brief, systematic thinning increases the vilne of the crop, and lielps to iusure full crops eacry year.

The tine to do the work is after the Jnne drop is about over and before the seels or pits have hariened. Often it is necessary to pull off, by liand, almost twothirds of the fruit on a heavily set tree; yet, strange as it may seen to those wlio liave not tried it, the

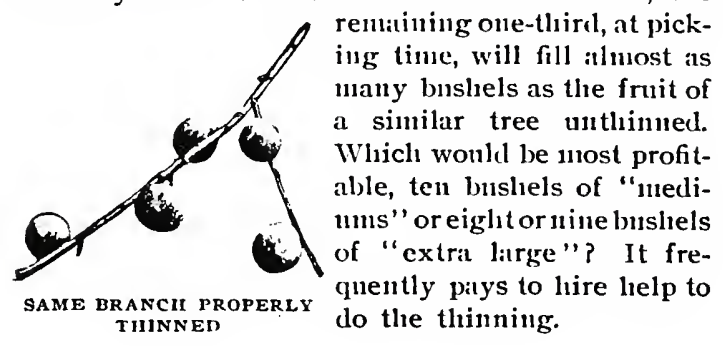




\section{NOTEBOOK JOT'TINGS.}

Cultivation should be shallow - two or three inclies at most.

A rope or handle to the harrow helps to guide the inplencul.

If you grow cultivated crops in a youmg orcluard, never let the crop conte closet than four feet to any tree trunk.

Many orcharclists say: "Don't plow or cultivate frnit trees while they are in blossom. May canse the enbryo fruit to (lrop."

When applying fertilizer, renculber that a tree's root area is usually as large aromul, or larger, than its top area. Don't pile tree foorl aromul the trink, - spread it farther out.

Use a one-horse plow for the first two or three romds along a tree row. Do this to all the rows. Then change to a two-horse plow, and finish the joh. This makes easier, closer work.

If you decide to mulch, do it right. Don't permit yourself to mow the grass which puslics through the mulch, and then remove the clippings. I,et the mowed grass lie cil the mulch.

Why slondl cultivation usually cense aiont August first? So as to allow the new grow th to stop growing and harden in) in profer nuature condition for the winter. 'The new wood on late cultivated trees is more apt to winter-kill.

Muzzle the horses when plowing or cultivating aromud trees. Yes, and don't forget to pad the outer end of cacl whifletree. Pad the outer cdges of the harrow, too. But if a tree is acciclentally "harked," handage the wombl with cow mamre and burlap.

Rules for lhiming fruit: Remese all wormy, croxked or

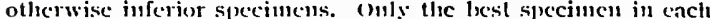

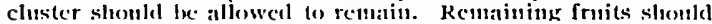
not be closer togettice than five or six inclies apart. Properly thinnet trees necd no props.

I,carm how to harrow an orchard so as to cover practically all the gromul. Ilarrow lengthwise one tine, crosswise another time, and diagonally the third time: then repeat. A careful driver will thms leave only a few inclies of untonched gromul aromnd cach tree trunk - and a hand hoe easily finishes that.

Squnctimes it is desirable to "seckl down" to grass, for a year or so, a thrifty. well-grown pear, apple or cherry orcliard. Plum, peacli or dwarf pear, never. Ami, in any case, sncli a conrse is seldom best until the trees have reaclied the bearing age; then, a temporary sceding down may be heneficial,-first, becanse it mas inclucc (finicker fruitfulsess by cliccking growlli; or, second, it may prevent the lark-burst or pear blight which a too rapid growtli sonetimes promotes. 

ILATE VI

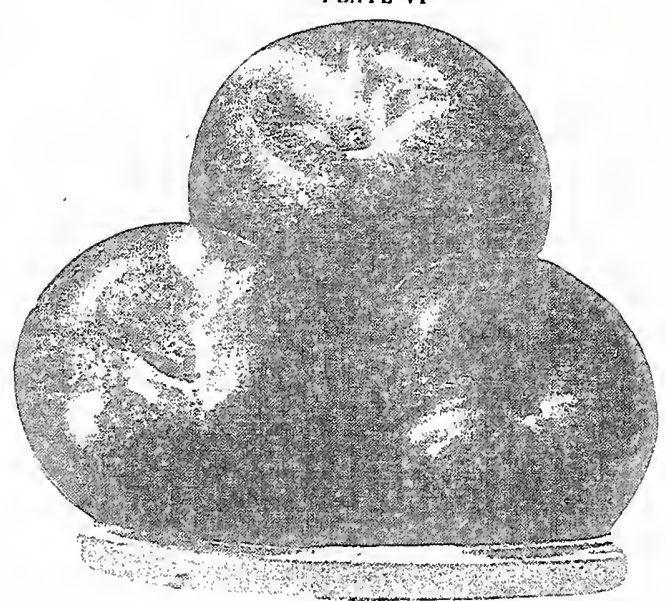

SPRAYED FRUIT

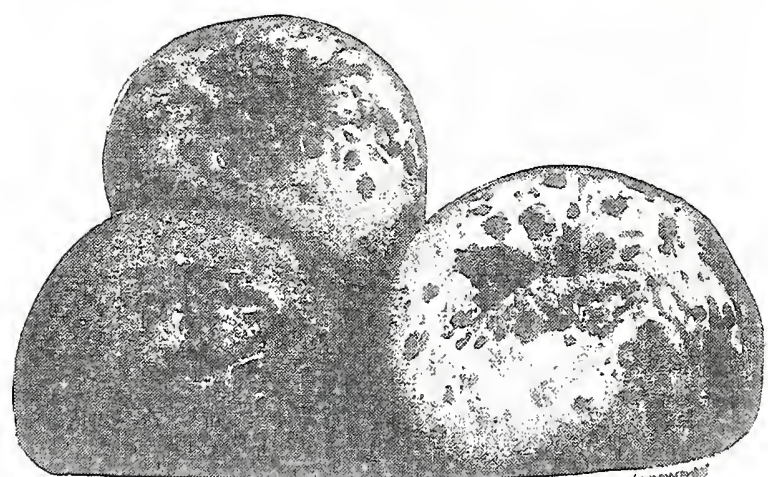

-

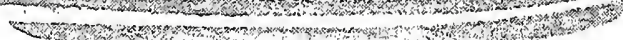

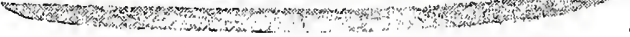

\section{NOT SPRAYED}




\title{
ChaP'TIR VII.
}

\section{SPRAYING.}

\begin{abstract}
Spray, fapmers, spray acrith rare,
Spray the apple, peach and petr;

Spray for siab, and spray for blight,

Spray, oh spray, and do it right.
\end{abstract}

Yes, that's the entire secret-"1)o it right!" livery year there is a great deal of spraying that does very little good. Matuy individuals go through the operation ancl sinply waste tine and money. I lave observed that unless the operitor is very careful there will be fruits ancl even large areas on the trees, left unsprayed. In many cases the operator sprays the lower linibs of the trees heavily, but the topmost twigs, and even the centre, are left dry, anil then he wonclers why spraying toes not produce better results.

If you are a fruit-groweractulal or prospective-inike up your mint to the fact that a gool spraying ontfit is just as inportant to your success as a plow or a pruning silw. The kind of an ontfit which you require depends, of conrse, on the size of your orchard. If there are only a few trees, of

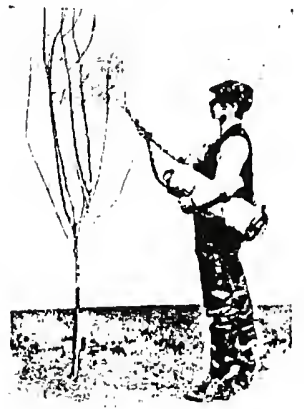

FOR A FEW TREFS, NOT TOO LARGE, TI TS COMI'RESSIEJ)-AIR OI'RAYER IS ALL RIdIIT 
medium size, perhaps one of the new-style, compressell-air, shonlder-strap sprayers (sold by seedsmen and implement dealers) will answer the purpose. Or if the trees are large or numerons, you may require

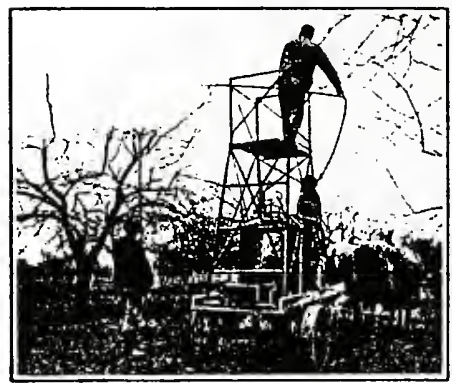

POWER SPRAYING FOR LARGE ORCIIAR DS

a barrel or tank ontfit, monnted on the farm wagon and workel by liand ; or perhaps your requirements may necessitate one of the power outfits which are operated by eitlier il gasoline engine, geared connection witl wagon

wheels, or compressed gas in cylinclers.

Before deciding wpon a punp, or buying one, take a bit of the same advice that IIarriet once gave to me: "Write to advertisers in the Farm Journal or other farm papers, get their catalogs and price lists, and then stully, compare, and decile."

A gool pmmp should work easily, maintain a stearly spray from one or several nozzles, be simple in construction, hitve non-corrosive brass working parts, be durable and able to stand hard use, be easily titken to picces for repair, hitve pipes properly arranged to prevent clogging, and be provided with an agitator which keeps the solution in vigorous motion and thoronghly distributed. Judging a pump 
by cheapness alone often proves poor economy. For a very finely divided spray the Vermorel nozzle seems the best of any tested at the Station, says F. II. IIall, Genevi, N. Y., and that form should be chosen which is provided witl a joint between nozzle chamber and elbow, to allow easy access in case of clogging. For spraying at some distance the MIcGowen nozzle is useful, and the double Vermorel is aclapted for thorongh, rapid work. A light banboo pole, enclosing a brass tube and fitted with proper conncetions, seems the liglitest and

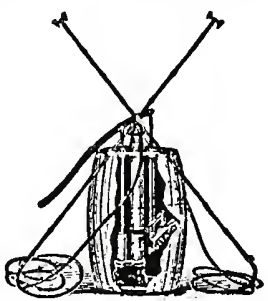

INARTE, SIRAYER -

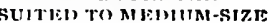
ORCHARIS: simplest means for raising the nozzles; this with a light framework tower erected in the wagon or cart upon which the operator may stand, will usually afford sufficient elevation for even tall trees.

Spraying mixtures are divided into two classes: Fingicicles and insecticicles. Often, however, it is practicable to nnite the two into one spray-and thus fight both fungus and insects at the one operation. A mixture of Borleaux solution and an arsenical poison, is a good example of such a combination. Borlenux mixture is the best and most useful of all known fungicides for general use.

IORDFAUX MIXTURF.- Four poinds of sulpliate of copper, four pounds of quicklime, fifty gallons of water. liirst, dissolve the copper sulphite. The easiest, quickest way to do this, is to put it into a coarse cloth bag and suspend the bag in a receptacle 
partly filled with water. Next, slake the lime in a tub, and strain the milk of lime thus obtained into

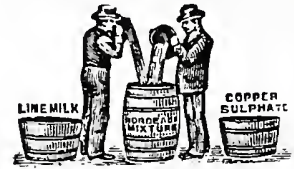

MARING BORDEAUX another receptacle. Now get someone to lielp you, and, with buckets, simultancously pour the two liquicls into the spraying barrel or tank.। Lastly, add sufficient water to make fifty gallons. (For making this mixtmre on at large scille, an elevated platform-with pipes, etc., as shown in cut-is very liandy.) 'Tis safe to use this fullstrength Bordeaux on almost all foliage,-except on peach trees, Japanese plums, and similar tentler trees. I'or these it is wiser to use the following half-strength mixture :

IIalf-strength Borleaux : Two ponnds of copper sul-

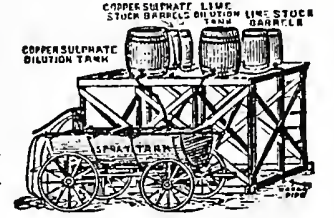

TLLEVATE JIAANT FOR MAKING HORDFAUX ON A LARGE SCALE pliate, two pomuls of quicklime, fifty gallons of water.

BORDEAUX COMBINED WITH INSECT I'OISON.- - By adding one-quarter poumd of Paris green to eacli fifty gallons of either of the IBordeanx formmlas, the mixtnre becomes a combineal fungicicle and insecticicle. Or, instead of paris green, add alont two pounds of arsenate of lead (an excellent commercial form of this, called "Disparene," is for sale by seedsmen). The advantages of arsenate of lead, over Paris green, are, first, it is not apt to burn foliage even if used in rather excessive quantities ; and, second, it "sticks" to the foliage, etc, better and longer. I believe that it is the best form in which to use arsenical poison. 
INSECTICIDFS.-Sometimes it may be desirable to apply a treatment for insects alone, withont the bother of making the regnlation Borleanx. Ilere are a few stanclard formulas suited for cliewing insects:

Paris green : 'Two pounds of quicklime, one-quarter pound of Paris green, fifty gallons of water. Keep 111ixture well agitated while spraying. (Not so safe as arsenate of lead on tender foliage of peacl, etc.)

Arsenate of lean: This can be male at home, as follows: Take twelve onnces of acetate of leat, four onnces of arsenate of sola, and fifty gallons of water. I'nt the acetate of lead into a gillon of water in a woorlen pail; in another woolen pail put the arsenate of soda in two quirts of water. When both are dissolved, pour them together into the spray tank containing the required anonnt of water. A white precipitate of lead arsenate immediately forms in the tank and the mixture is ready to be applied. This remains in suspension longer than Paris green.

For SUCKING INSECTS. - Now we come to another class of insecticides, suited to insects which snck a tree's juices but do not chew. Arsenic will not kill such pests; therefore we must resort to solutions which kill by contact. Ilere are some of the bestknown recipes of this kind:

Kerosene emulsion: One-half pound of liard or one quart of soft soap; kerosene, two gallons ; boiling soft water, one gallon. If hard soap is used, slice it fine and dissolve in water by boiling; add the boiling solution (away from the fire) to the kerosene, and stir or violently churn for from five to eight ninutes, nutil the mixture assumes a creany consistency. If 
a spray punp is at hand, punp the mixture back upon itself with consillerable force for allont five minutes. Keep this as a stock. It must be further diluted with soft water before using. One part of emulsion to fifteen parts of water, is about riglit for lice.

Whale-oil sonp solution: Dissolve one pound of wliale-oil soap in a gallon of hot water, and dilute with about six gillons of cold water. This is a good application for the young lice of the oyster-shell and scurfy scile (see Chapter VIII), or for aphis.

Tobacco tea: This solution may be prepared by placing five pounds of tobacco stems in a water-tiglit vessel, and then covering themn witl three gallons of hot water. Nllow to stand several lours; dilite the liquor by adling about seven gallons of water. Strain and apply. (iood for lice (aphis) on foliage.

Special Remarks. - No attempt has been made in this chapter to cover the various fungous troubles and insect pests which do damage to orcharis and fruit,- sucli topics being more appropriately treated in the chipters on The Apple, The Pear, etc. There you will find special directions which fit the special pests which prey on each kind of fruit. Scale insects liave a cliapter all to themselves.

rim wants ne to sily thit fungiciles are not cures, but procentiz's. "Mlierefore," he concludes, "the early bird catclies the gerı1." By which he means, of course, that the sprayer should begin early in the season,- before fingons trouble lias really begun. "Yes," adds Inarriet, " and lie sliould repeat the good work several times, at intervals of two or three weeks apart." 


\section{IIHII'I'LI, JIN'TS.}

Bordenux mixtme is lest when used a few hours after being mixerl.

After spraving, punp air or water through the punp and hose to elean then of the nixtnre, so that it shall not needlessly corrode them.

All spraying mixtures shonkl be constantly agitated when in use. If this is not done, some of the ingreclients (particularly Paris green) are apt to settle to bottom of tank or barrel.

A properiy thrown spray is a fine mist. like stcan; it showidn't he i fall of raindrois. It slomld settle on a tree like dew, nnd there need be very little "Irip" npon the gromind.

Ncver spray trees while they are in blossom. No need to do it, and it would kill the orchardist's lyest friend-the bees. without bees, blossons would not be properly cross-fertilized.

Jon't try to cover all silles of a large tree at onc operation. Tate one siele nlows the row, llew when the wint is favorable conte back on the olleer sicle (for lack of this precantion many trees are half-chal on that "other" side).

If rain falls innuediately after an application, it must be repeated as soon as the plants are fairly dry again. Jut if the mixture once gets dried on the foliage it will adhere very well in spite of rains. Irom one to two hours of sunshine will dry it satisfactorily.

A few fruit-growers favor the dust method of spraying. Instead of liquicls they use powdered forms of insecticides and fungicjles, blown into the trees by neans of special apparatıs. The idea cloubtless has some gool points, hut a liquid spray seems to suit most folks best.

A. W. Cheever tells in Farni Journal of a contrivance that will be a booll to the n1111 who holds the sprayer rod,-consisting

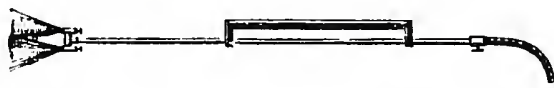

of an extension to prevent the liquid getting on the hands. The pipe has a rod attached set off about fout inches, for grasping by the hands. This does not get wet as does the tube.

Straining J3ordeanx mixture: No matter what quantity of mixture is to be macle np, it is necessary to strain the materials through a good strainer. The best type of strainer is made of brass wire, with eighteen or twenty ineslies to the inch. If all the copper solntion and milk of lime are separately strained, it 
will not he necessary to strain the lholeanx mixture itself. Sonte very good strainers mate of eoplere ate on the matket and may be obtained from the makers of spray pminps. (Ine of the best, which can be made at houne, is in the form of a box.

Extra-strong Bordenux mixtures: Some spraying experts advocate the following extra-strength formulas: Six pounds of copper sulphate, four ponnds of quickline, fifty gallons of water. Or, five pounds of copper snlpliate, five ponnds of quickline, fity gallows of water. I think these are too strong.

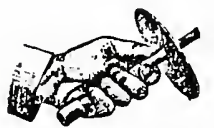

llere is a picture of a disc-shaped sintay-

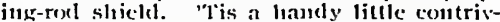
ance for preventing the spray-thip, from running down the rod on to the hands. Can be made of metal or wool, tiglitiy fitted.

It has luen established that in the casc of the apple crop, sprasius will profect frum fifty to scoenty-five per cent of the frisit, wilicls would otluerwise le worms, mut that in actual marketing cxperience the price has heren enlanced [rom $\$ 1$ to $\$ 2.50$ per loarrel, and this at a cost of only alwut ten cents per tree for labor and material.

In the case of one orchard in Virginia, only one-thiru of wlicli was sprayed, the resılt was an increase ju the vield of sonnd frnit in the portion treated, of nearly fifty per cent., and an incrcase of thic valuc of this fruit, oter the rest, of olle

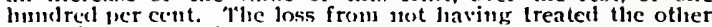
two-thirls whs estintated at $\$ 2,500$.

1t must be romembered that most spraviug materials are poisonous and slould he so labeled. If ordinary precantions are taken there is no danger, to man or tcan, attending. their application. 'l'he wetting, which can not cutirely lue avojded, is not at all clangerons, on account of the great dilution of the mixture. Nor is properly sprased fruit intsafe to cat.

In large oreluarals much time may be saved by preparing and kecoing on liamel separale steck solutionts of the lime and copper. insteal of constantly making a1) a new batch. bissolve forty poinds of copper sulphate in as many sallows of water. $\Lambda$ saillon of the solntion will thus contain one ponnd of the colper silt. In a sinilar way a stock solntion of lintc uay be prcpared. Keep both solutions tightly covered and thoronglily stir lefore dipping from either. It is then a very simple muatter to take four gallons of the copper solution, four of the line, anul dilute to the requisite amount, - according to the regulation Bordeanx formula. 

['I.ATE VII

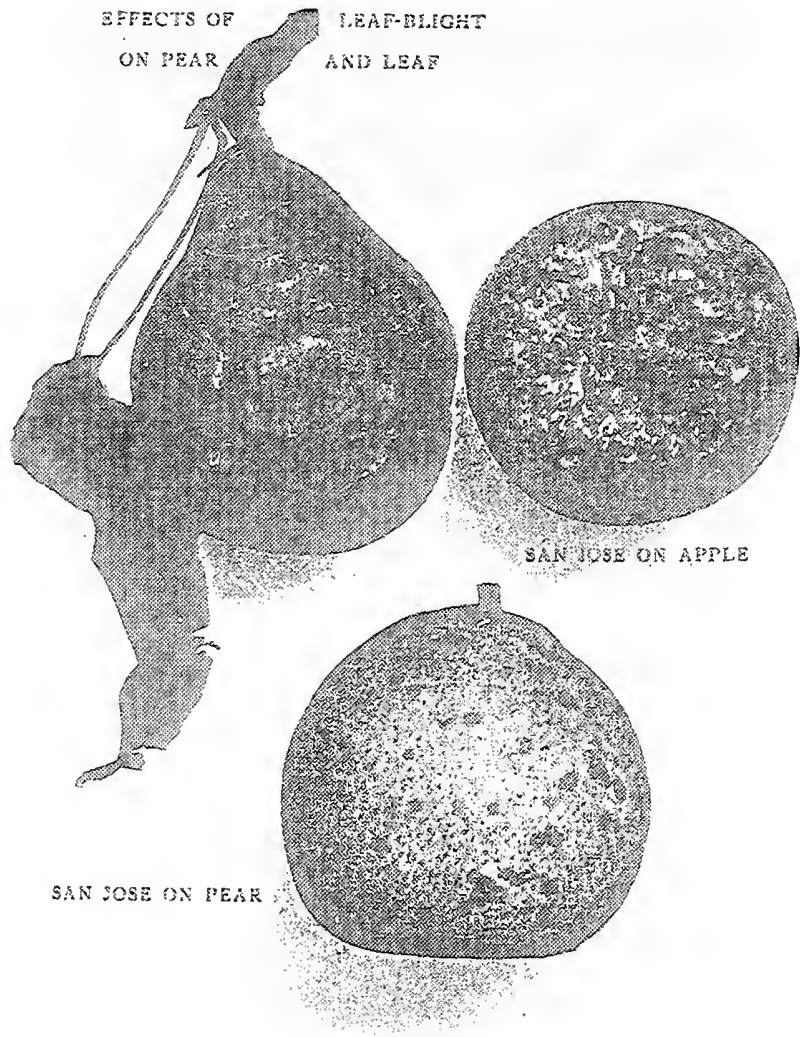




\section{CHAP'TIER VIII.}

SCALIE l'ISSTS: SAN JOSE, OYSTIER SIIILL, SCURIF, Ji'C.

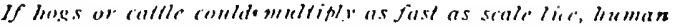

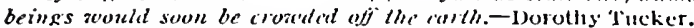

The most serions insect pest which confronts the orcliarlist of tolay, is mulonbtenlly the Sin Jose scale louse. It came to this comntry on mursery stock from Jaj:an, amul first louk root in sim Jose, Cal. It is supposeel thit it wi!s loromglit cast to New Jersey alomt twenty years ago, and it hits grimlually spreal mutil now it menaces the larger part of the United States.

In a single seison a female maly become the pro-

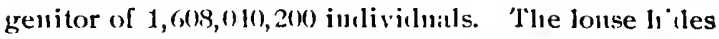
muler a seale thit is impervious to most insecticides.

It attacks all orcharil trees, roses, sminll fruit bushes, and many lawn slirubs and rines.

The louse call crawl rapidly, and is often carried by birils, insects and lieavy wints.

Ilie insects are too small to be easily seen with the naked eye, but the scale can

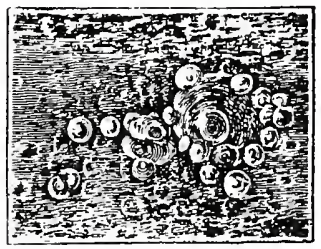

ADULT MIENAI,E SAN IOSIE SCALE WITH YOLINC: (ENIARTIED, AS SIEIIN THROUGII A MAGNIIYING GLASS) be seen. Bark of affected trees has a grayish or ashy appearance, in bad cases. It is the louse and not the scitle t'iat does the liarum. 
Now search all of your sick trees, and here is a description that will help yon: 'l'he Sin Jose scile is rather flat, romd, pressed close to the bark, and of ten is grayish, or resembles the bark of the twig in color; when fully grown is abont one-eighth of an inch in dianeter. At or near the middle of each scale is a small, romnd, slightly elongated, black point or nipple. Badly infected trees are covered so thickly that the bark is completely hidden. Such trees must be destroyed or severely pruned and thoronglily sprayel. A magnifying glass (the Farm Journal folks sell a gool one for fifty cents) shoild be a part of every molern orchardist's eqnipment. Now remember: $A$ ronnd, dark scale with a contral dot or nipple. 'That's the idlea, in a nutshell. (When fonnd on the fruit, each scile is usinally surrounded by a reddislı ring. See colored plate V11.)

The best time to fight the Sinn Jose is in the early spring while the leaves are off and before the buds swell, but if your trees are baclly scaled over, and half deal, it will never pay to try to save such trees; dig them up at once and burn every vestige of them. Do not lose a day in this; now is the word. Near every badly affected tree will be fonnd other trees that show the scale to the close observer; these may be left standing until winter. Then, soon after the leaves drop, spray the trees; and, if you wish to be thorongh, follow this with a second spraying in early spring before the buds open.

Since the Farm Jonrnal, four or five years ago, bronght the lime-sulpliur-salt spray to the attention of fruit-growers east of the Rocky mountains, many 
other things have been tried, but to little purpose. The line, sulplur and salt mixtnre is still the sovereign remedy on the l'acific const, no other naterial being used there to any extent as a scale spray; and elsewhere in the United States it is the best thing yet found. It is effective wherever nsed, if directions are followed, and it is safer to nse than the oil remedies sometimes recommented.

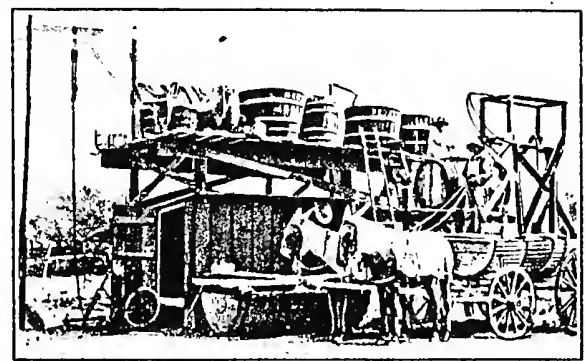

AN ILIINOIS IIME-SULPIUR-SALT OUTFIT. STEAM-COORING IN ELEVATED BARRELS

Iarm Jonrnal's winter formula for naking the lime-sulplinr spray: "Mix forty pounds of fresh, mnslaked line in sixty gallons of water, and after stirring in twenty pounds of sulplur, boil the mixture one and one-half lours. Strain thronglı wire sieve or netting, and apply while mixtnre is still warm. A good, high-pressure pump is essential to satisfactory work. Coat every pirticle of the tree. The salt is purposely omitted, for it does not seem to do much good and it renders the nixtnre liarder to manage." 
Dr. Funk's formula for the line, snlphur and salt mixture is as follows: "Io make 150 gallons, take sixty-five ponncls of best stone line, fifty ponncls of sulphur and thirty-five poumcls of silt. Make a paste of the sulphur and have from fifteen to twenty gallons of boiling water in an iron caldron over a brisk fire. Into this put the lime, immediately adding the sulplunr paste. This is rapidly cooked, eitluer thirty, forty or fifty minutes, or mutil it looks as red as canned tonntoes. It munst be vigoronsly stirred all the while, when it will get as smooth as gliss. Then add a sufficient amount of hot water to make 150 gallons."

The montl of Marcli is the best nonth in which to spray, if onty one application is given. Here is J. II. Ilale's way with the lime, sulplutr and salt formula: "'Twenty ponnds of best lime dinnped into boiling water will generate a heat that will generally melt down fifteen pounds of sulphur flour. That should be dumped right in after the lime. Then by steam or fire heat keep this mass boiling thirty to forty niniutes; add water to milke fifty gallons; fifteen pounds of silt (to make the mass stick to the trees longer), and you have the best lime-sulpliur-salt mixture that can be made."

Prof. S. $\Lambda$. Forlses gives the following directions for nlaking what is known as the Oregon waslı: "Provide thirty pomnls of best nnsliked line, thirty pounds of powdered sulphur, three pounds of blue vitriol, and water sufficient to make 100 gallons. Heat five to seven gallons of water in an iron kettle, and, while this is heating, weigh out the lime and sift the sulplur, keeping the two separate. When the water is ready 
to boil, put in the lime, and as soon as this begins to slake pour in the sulplunr, one man vigoronsly stirring the mass during this operation. $\Lambda$ violent boiling inmerliately takes place, and valter-preferably lotshonld be kept at hamd to pour on the boiling mass to prevent its running over the kettle. Use as little water as possible, continnonsly stir, and clo not allow the mixtmre to boil over. When the line has finished slaking, the riolent boiling ceases, and the mass shonld be thick and stiff. Keep it steadily boiling for an lour. The mixture becomes thinner as it boils down, and chinges from a deep orange-red throngh several sharles of yellow, ending with a deep amber color. When it reaclies this color we usually consider it tine to acld the blue vitriol. Then fill the kettle with lot water, thoroughly stir, strain onc-half the contents into a fifty-gallon barrel and fill the barrel with hot water. Spray this upon the dormant trees inmediately."

OYSTER-SHEI,L IBARK-LOUSE.-The most common scale-insect of the apple, withont donbt, is the oysterslicll bark-lonse. Although everywliere present, and sometimes quite conspicnous, it most of ten attacks trees that for some reason are muliealthy, and therefore poorly fitted to support the extra drain put upon them by the pest.

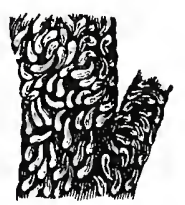

The scales of these insects are elon- oyster-sner. gated, shaped something like oyster- BARK-LOUSE shells, with the cast skins at the smaller ruLc size) ends. They are brown in color. Underneath a scale will be found a clister of yellowish-whitish eggs, 
plainly to be seen throngh an orlinary magnifying glass. The scales are about one-eighth inch in length, or smaller, and they usually cluster together as shown in the illustration on page 71 .

About the midlle of May (later or earlier, according to latitu(le) the eggs muler the scales liatch into tiny lice which appear as mere specks to the unaided eye. 'These lice, for a few dias, move around on the bark.

Remedies : First, give the tree a tonic and a good rub-down. Fertilizers, pruning and cultivation will help the tree to better general liealth; and a brisk scrubling of trunk and main liumbs with a very stiff brush or scriper, will get rid of minny of the sciles. An old brooun witl the brush cut short mikes an excellent scrubling implement. Keep it wet with whale-oil soip solntion. 'Then, sometime in May, watch for the hatched-ont lice. When they appear, get out the spray pump and thoroughly spray the entire tree with whale-oil soap solution, miale as follows: Dissolve one ponnd of whiale-oil soap in a gallon of lot water, and dilute with about six gallous of cold water. (Note : The oystersliell louse is especially fond of the lilac.)

SCURFY BARK-LOUSE.-Anotlier scale insect, that may be classed witl the oystersliell bark-lonse so far as its econonic iniportance is concerned, is the scurfy bark-

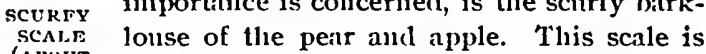

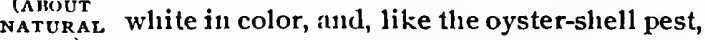
SIZE) is niost apt to work on poorly fertilized and poorly cultivated trees. The scurfy scale is readily recognized on account of its whitish, cotton-like 
appearance, and its oblong shape. 'The eggs beneath the scales are in clusters, purplish in color, and they liatch out abont the same time as the oyster-shell eggs.

Ren1edies: Same as for oyster-shell bark-lonse. (Special note: There is no better remedy for all scale insects, than the line-sulphur-salt spray. Those who use it on their trees in the winter, are all right. But when tree growth is beginuing, it is better to fight oyster-shell and scurfy bark-lice with while-oil solution. Or kerosene emulsion may be used.)

OTHER SCALE I'ESTS.-A variety called the " plum scale" is sometimes found on plinin trees (and occasionally on quince, apple, pear, cherry and peaclı trees). Of this scale pest l'rof. Slingerland says: "They remind one of smill hillved peas colored lark brown and stuck on the branches." 'They belong to the scale family named Lecaniums, several species of which are serious pests in citrus orcliards.

Olive and citrus fruit-growers in California, Florida, etc., have a long list of scale tronbles of their own. The same remedies advocated for other scale pests will prove equally successful when applied to the plunil or citrus or olive scales.

\section{FOO' NOTFS.}

For the lime-sulphur-salt wash the pump should have brass working parts ; nothing should be of copper.

Ladybirds are anong the most active destroyers of scale insects, and the most abundant of these beetles is the twicestabbed ladybird.

All dead wood and thick brush slonid be cut ont before attempting to suray; nud all branches that are too higli to reach and cover with the spray liquid should also be cut off. 
Frotect the hands by coating them with vaseline or by wearing gloves-rubler being the least injured by the lime-sulphnrsalt wasl. Cover the horses. Spray only with the wind, if it be too strong to spray against it. It is impossible to throw the suray satisfactorily against a very strong breeze.

Spccial note: Many folks lo not fully realize that the limesulpluur-salt spray is a splendid fungicide as well as a louse killer. Tlierefore $i t s$ use may well take the place of the earlier Bordean applications, before the burls have opened. (Full-strengthlimesulplurr-salt is not suited for spraying on trees in leaf.)

A fifty-gallou barrel makes a very convenicut mit for even the most extensive spraying operations, says M. J. Waite. Ilcre is a plan of line-sulplunr-salt looiling plant of six barrels, rather similar to the nioklel of J. H. Jialc. (1iig. I shows general view; fig., II shows details of one barrel.) The boiler rests on the gromul, the barrels and the water-supply pipe on an elevated platform alont eight fect

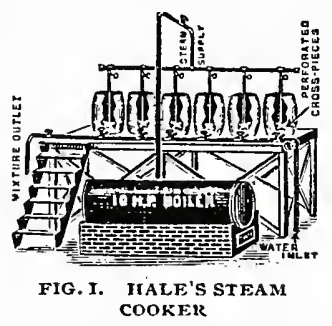

from tl:c grommol. The ontlet is terminated by abont

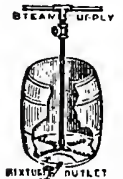

thrce fect of flexille hose, through which the finished mixture can be pipcel to the wagon tank as wanted. 'he stean is condincted directly into the bottom of each barrel, escaping into the liquid through the perforated crosspices, and then bubluling np and ont. The water inlet and ontlet pipes liave no comection, of conrse, with the stean pipes. Stop-cocks should

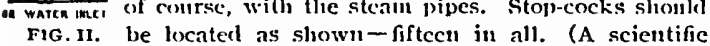
MARRI, friend of mine suggests that a steam coil in the

DETAII.S lyottom of each batrel, throngh which steant conld pass and then return to the boiler, would be more economical of steam and of fuel. He says that it's wastefnl to allow the steam to escape in the barrels. - J. B.) 



\section{PLATE VIII}
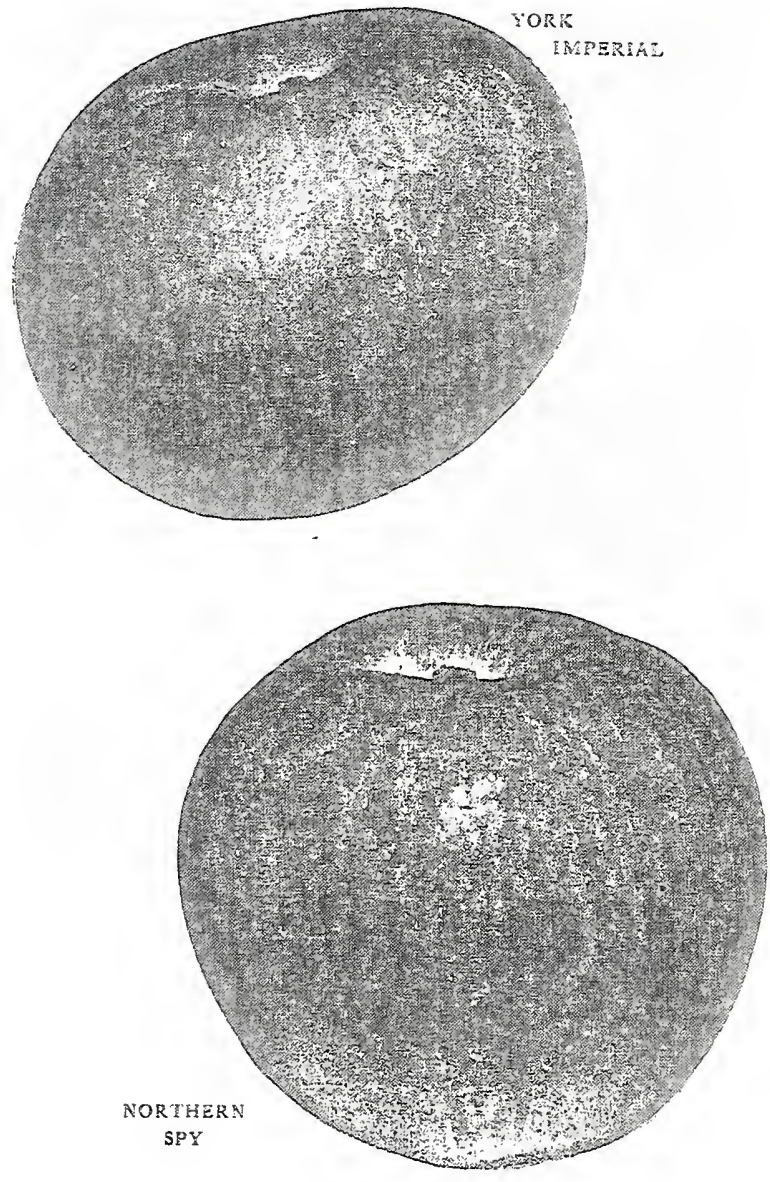
Chapter IX.

COVIER CROPS.

I*AII, WINTTER ANI) SPRING CARL.

Orchards, as well as folks, need winter overcoals.-John Tucker.

The seven important arlwantages of a cover crop in the orchard are: $1 \mathrm{st}$, to supply nitrogen and organic matter or humus to the soil; 2 l, to improve the ntechanical condition of the soil, $i . e$., to lighten a heavy soil or make a light soil more retentive of moisture; $3 \mathrm{~d}$, to protect the roots from being injured by deep freezing; $4 t h$, to prevent the fine particles of soil and plant food from being washed away during the fall, winter and spring; 5 th, to catch and hold snow and leaves; $6 t h$, to lielp clieck late growth of trees in the fall, and thus aid wood growtl to harden up for winter; atucl, $7 \mathrm{~h}$, to pmup the surphus water ont of the soil in early spring so that the gromul may sooner get into conclition for plowing.

An orchard cover crop is a crop sown to cover the ground dinring that portion of the year when very little or not any growth is being made by fruit trees. If a man makes no effort to cover the gromud with economic plants, then Nature steps in and starts weeds and grass in the endeavor to protect the soil. Cover crops are usuilly sown just before the last cultivation of an orchard-abont $\Lambda$ ngust first. Sonetimes as early as July, or as lite as early September.

There are practically two classes of plants whicls the orchardist may use for the purpose of securing 
a cover crop, says John Craig, Cornell Experiment Station, New York. These are: the nitrogenous class on the one hand and the non-nitrogenous class on the other. The difference between these two is marked by the power of the plants of the nitrogenous class to appropriate the free nitrogen of the air and store it np in their tissues in such a way that it is more or less readily available to the succeeding crops. Prominent anong plants which have this property are the clovers, peas, beans and vetches. 'These are the farners' friends - the "nitrogen collectors."

Prof. C. P. Close, Deliware, says:-"Tlie amounts of seed per acre, ancl crop or combination of crops which may be used, are about as follows: Rye, one to one and one-lialf bushels; cowhorn turnips, one to two pounds; dwarf Iissex rape, eiglit to ten pounds; red, mammoth or crinson clover, fifteen to twenty ponnds; cowpeas, ninety pounds; soy beans, ninety pounds; hairy vetch, forty to fifty pounds; liairy vetch, forty pounds, and rye, thirty pounds; hairy vetch, twenty pounds, and cowpeas or soy beans, forty-five pounds; hairy vetch, twenty pounds, and turnips, twelve ounces; hairy vetch, twenty pounds, crimson clover, eight ponnds, and turnips, eight onnces; hairy vetcls, twenty pounds, and red, man1moth or crimson clover, eiglıt ponnds ; turnips, eight onnces, rye, twenty pounds, and red, mannoth or crimson clover, four ponnis ; turnips, twelve onnces, and crimson clover, eight ponucls; turnips, twelve onnces, and soy beins or cowpens, forty pounds; dwarf Essex rape, four pouncls, and rye, one busliel ; rape, four pounds, soy beans or cow peas, forty pounds, 
and rye, twenty pounds; alfalfi, fifteen pounds, and red, mammoth or crimson clover, seven and one-half pouncls."

Many other combinations maty be used snccessfully. The object shonld be to use such a mixture of crops that a part at least shall live over winter. $\Lambda$ few of the foregoing combinations contain all fall crops and for that reason are not so desirable as thougli they contained a part of those that live through the winter and grow in the spring. Oats; one bushel, crimson clover, ten ponnds, is by many fruit-growers considereil a gool combination. The oats die down when cold weather comes, and help protect the living clover.

Fall, WINTER AND SPRING Care.- 'This consists of several things, the nost important of which are: Protection against injury by mice or rabbits; protection against sun-scald; protection against live stock; careful oversight of drains and drainage; sifeguarding, so far as possible, against late spring frosts at blossoming time; and lumting for borers. Ilints on these and other subjects will be fonnd in the following

IIHLTS FOR I'RUIT-GROWF,RS.

A lolt jut in, now, many save nine busleels of fruit later. Split trees and dangerons crotclies need attention. Jolts are clieap. Use 'ems.

wintcr and carly spring afford excellent chances to find and destroy all cocoums, curs clusters, etc., on fruit trees. Make a practise of doing this eacli year. It pays.

Jhe carefill not to let the cover crop grow so late in the spring that it pulls all the moisture ont of the soil. Rye, etc., should be plowed under before it becomes tall andi wooly.

Cows, sheep, etc., bave no good excuse for being in an orchard at any time. 'There's always clanger that they will bark the trees,-especially when green forage is absent. 
When fall comes, be sure to clcan up all trash in the orchard. Mow the weeds (there shouldin't be any). Juirn all rubbish. 'Then the owls, hawks, cats and crows can readily see and catch all field mice.

Trees which have beell completely girdled by mice or rabbits, can often be saved ly neans of bridge grafting. (See Chapter II.) I'artially-girdled trees should be bandaged with cow nuanure and burlap.

An experienced orchardist says that it is an excellent plan to leave the elippings nuder the trees in the winter when pruniug an oreharel, so that mice and rabbits will eat such tender twigs insteal of guawing at the tree trunk itself.

Dornant buds : Sounctines crery fruit bud or blossom on a tree will seem to be killed by cold, and yet-to most folks' surprise-a noderate crop of fruit results. How? By means of the dormant (nudereloped) buds on the trees. When normal buds are killed, the trees often force forward the dormant ones in time partially to supply the deficiency.

Good drainage in the orchard is cssential to snccess. I,ike human leings, fruit trees call not stand wet feet. In the fall a furrow-ditch plowed between tree rows, or wherever needed, may help to insure better drainage conditions during the winter and early spring. See that tile drain ontlets do not hecome obstructed : to keep out smiall animals, fasten wire netting over each outlet.

I'ruit buds: These are apt to be more plump than leaf luds. and are therefore usually easily rccognized. Slice a fruit bud through the centre, lengthwise; if it is alive, the interior is greenish-yellowisln in appearance; if dead, the heant is blackened, evein thongh the remainder of interior looks all right. Frozen buds should he thawed ont for several days before making this test.

Scvere pruning-hack is the most effective trcatment for badly fromen very youmg peacli trecs, ete. Morerate cuttiug-back is best for less seriomisty affected votme trees, amel also for batly injured oll peacle trees, cle. Citrus trees, e'tc., will oflen spront again from a mere stump. (iive all frozen trees a fair chance; never pull ont a tree nutil it has had an opportunity to recover. Nature sometimes performs wonklers in this line in one or two seasolis.

Farmers who have been putting axle grease on their trees to protect them from rablits, sheep and vermin, should not do so. It is not a good plan. 'Tlie sun shining on the greasy hark drives the grease into the tree and may $k$ ill it. The best thing to use is beef blood, such as is casily obtinined in any slangliter house; then mix it thoronghly with clay and wood ashes. The ashes act as a germicide, while the clay forms a paste which preveuts the blood being readily wasled of by the rains. 
Blosson knowledge: 1. Scarcely one fruit blosson in ten sets fritit, even in the most favorable seasons and with the most productive varietics. 2, 'Trees making a very vigorens growth may drop their blossoms. 3. Brownt rot, apple or pear scab, and pear bliglut may kill the blossoms. 4. Frost injury to llossoms is of all degrees. Even flowers which appear to be uniniured may be so wenkened that they can not set fruit. 5. Rain during the blooming season prevents the setting of fruit, chiefly ly destroying the vitality of the pollen, injuring the stigma, or by preventing fertilization because of the low temperature. The washing of pollen from the anthers seldom canses serious loss. 6. If a tree stands alone and does not bear fruit, it may be self-slerile.

Sun-scald is nswally canscd liy allernate frecoing and thawing, which eventmally bursts the batk on the sonlhward side of the tree trumk near the gromm. Sometimes, how. ever, it is cansed by the sum striking too lot in summer on exposed branches or trunk. It is a serions tromble in sone orchards and with some varicties, and the only sure remedy is to sluade the trunk in some mamer. Wrappings of wool vencer or laths answer the purpose, ecencrally sileating. Besides, such wrappings fence ont nice and rabbits. I carncstly advise my brother orchardists to avail thenselves of this domble protections. Wood-vencer tree protectors may le purchased for about $\$ 5$ jer 1000 , and will Jast several years. J'roteclion ayainst sun - scald and rabbit injury is especially mecessary for young trces.

Abel F. Stevens says:-"Spring frosts have

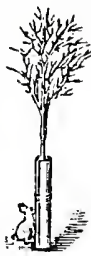

VEN TEER

TREF caused an immense amount of clamage. We liave PROTICTOR ben very successful in combating the baneful effccts of killing frosts by the following method: Mix coal-tar with sawdust and old straw, and place in licalps on the windward side. When leavy frosts threaten, set these heaps afire. 'They will burn for many honrs, making a dense smoke whicl complelely protects blosinus or fruit." An excellent iclen, surely. In this connection I would say thit some weslern oreluarclists are nsing an electric antomalic alarm thermonceler, to give warning at night when frost damnge llirealens. Alhis sive's the owner the trouble of

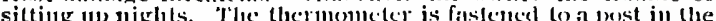
orchard, and wires run from it to an alarm bell in lise lususe bedroom. If the cold renclics the danger point, the bell rings, and the fruit-yrower can then hasten ont and light his smudges. Let me say, further, that sprinkling or irrigating an orchard when frost threatens, is often an excellent preventive of frost injury.

leware of borcrs: Various kiuds of loners-fat, whitish worms - atlack thic different varictics of fruit trees: there are the apple-tree borers, the peacls-tree borers, etc. etc. It will be wise to begin looking for sigus of these pests the fall or spring 
following the sctting of the trees, and, during the life of the trees, this anmal inspection should be continned. Carry a slsarp, small-bladed $\mathrm{knife}$, a piece of stont, flexible wire, and a trowel or spade. Fixamine each trunk ncar the groumd for traces of "sawdinst" or "guml" (the last, of conrse, will le found only on trees like the peach and cherry). Hither or both of these signs, when fonnd, show that one or more horers prolnaly lurk within, So, down your-gro on your knees; the soil is pulled away from the trumk to a deptli of scveral inches-and the war is on! With knife and wire the borers' burrows are probed until the enenty is fonnd and killed. Then on to the next tree. A few carefnl cuts in the bark do the tree

far less injury than the damage an MOR ER numolested borer will do. So don't he afraid. (Note: Some

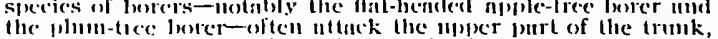
mud even the lower portions of the main limbs. The ucach-trec borer and the rombl-licaded aplile-tree borer usilally ntiack the trunk at a point close to the gromel.) Anong preventive mcasntes are screral methods which are sometimes successfully used to keep borers ont of the trees: Monnd up the earth to a heiglit of a foot or nsore aromind eacli tree, in May, and then allow the earth to remain until September. Or, protect the lower part of ench trink (during the same period of time) with closely-wrapued building paper. This paper should extend an inch or so below the ground surface, and about two feet above it, and he securely tied in place. Or try this wash: Dissolve one pound of hard soap in two gallons of boiling water; then add one pint of crnde carloolic acid, an onnce of Paris green, and enongli lime to make a thim paste; apply with a brush to trunks and larger branches of trees; if bark is rough, scrape trunks before applying wash. 



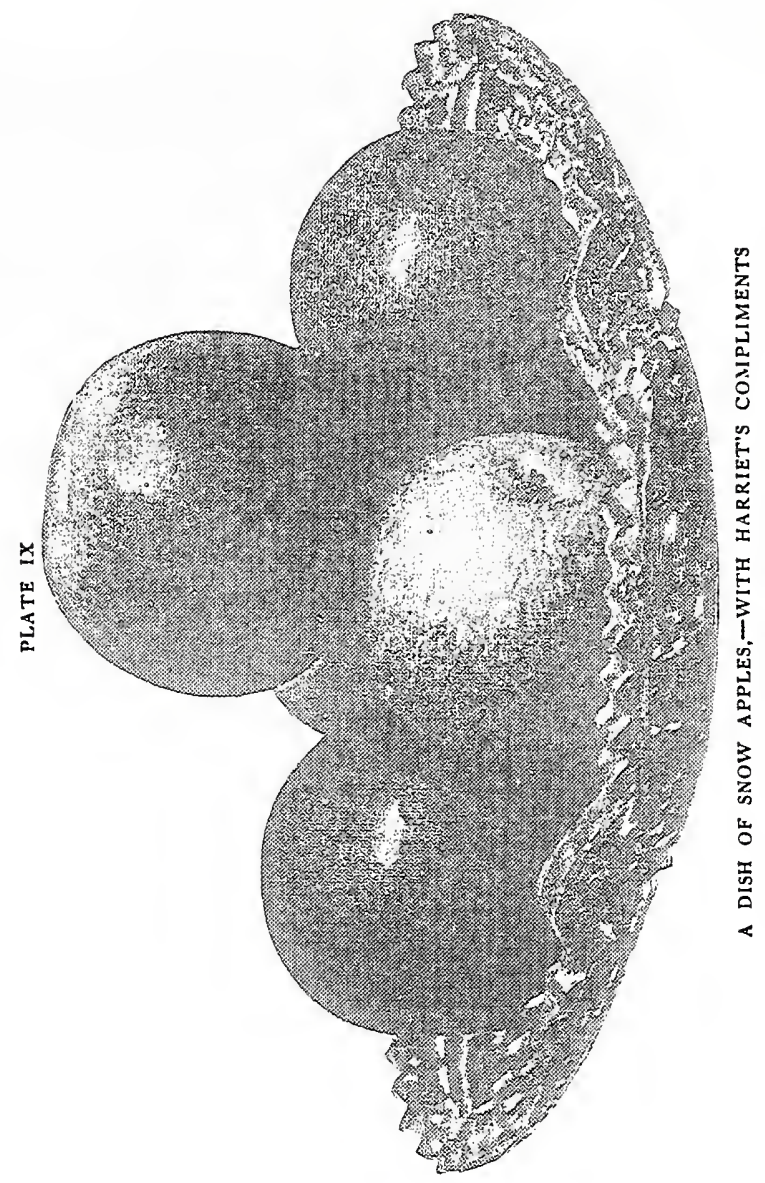


Chapter $\mathrm{X}$.

T11: APli,

If there's a better frut than an apple it's another apple.-Tim.

'This splendid fruit is almost as "old as the hills." King Solonion appreciated gool apples. Aud cliarred remains of apples have locen fonnd in prelistoric dwellings in Enrope. Sonthwestern Asia is where this fruit originated. IIarriet sitys that it is the "best joh that Asia ever dicl," and I agree with her.

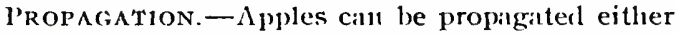
by grifting or bulding, the former nethou being most commonly used by nurserymen. Whip grifts on seedling roots are of ten eniployed. IBnt there are several watys of obtaining goot trees for setting. My frienl, Wilmer $\Lambda$ thinson, says: "If I were to plant another apple orchiri, ] should buy Northern Spy nursery trees, set them, and cut off and cleft-graft (after the tree is set) eacli trunk at the point where the first branclies are wanted,- - sing scions cut from thrifty bearing trees of knon'n a'aricty and productizeness." 'To Mr. $\Lambda$ tkinson's excellent plin I might add that if a man lats time, and can't afford to buy the trees, he might grow Spy seedling trees and then graft then1 - tluns saving the mursery bill.

SELECTING NURSFRY TREES. - Two-year-old, straiglit, medium - size, liealthy trees are abont right. See that they are not hranclied too high ; three or four feet slonld be the linit. 
Sorts. $-\Lambda$ lnost any soil will do for the apple orchard, provided that it he somewhat elevated and sufficiently well

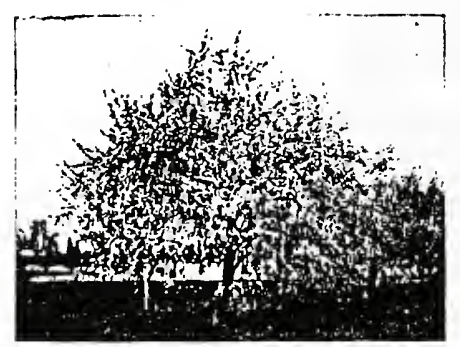

MAY'S PROMISE drained. Very light simel, or swimpy nunck, wonld be least desirable; a loany clay soil, most desirable.

VARIE'TIIS WHICH ARE OHTEN SELFST E R I L E."Bellflower, Primate, Spitzenburg, Willow Twig, Winesap," says Cornell lixperinent Station. Some other varieties might be adled to this list. In fact, the only safe way is to mix the planting, and to include some of the nore self-fertile-blosson kincls,such as "Baldwin, Ben Daris, Fallawater, Jannet, Oldenburg, Rloole Island Greening, Astraclian, Snith's Cidler," etc. (And even some of these are self-sterile in some locilities ancl nuter some circumstances! So I again sily, "Mix.")

P'RUNING. - Apple trees shonld be cut back (so as not to grow too high), thinned ont (so as to let snnshine and air into the head), and trimmed up (to permit of necessary loorse cultiva- FULFILLMENT tion). l'or general pruning directions, see Chapter V. Moderate, regular trimming is preferable to heavy, 
irregular trimming. The apple produces its fruit on twigs or fruit spurs which are at least three or four years old.

I'RINCIPAL INSECT P'ESTS. $-\Lambda$ plis (lice) on leaves. Rentedy: Spray with tobacco solution when lice first liatch ont and before they are lindden by curl of leaves.

Apple maggot: $\Lambda$ tiny worm which tunnels the fruit in all directions. Remedy : l'romptly pick 11 p and destroy or feed to the stock all windfalls.

$\Lambda$ pple-twig borer: $\Lambda$ tiny blackish beetle which bores into terninal twigs near buds. Infested twigs of ten wilt and die. No gool remely is known, except to cut off all such twigs, not later than July, and burn thein.

Borers: Two kinds-"round-headed" and "flatheaded." See Chapter IX for borer remedies.

Bud worm : $\Lambda$ little caterpillar that attacks lutils, blossoms and starting leaves. Remedy: $\Lambda$ rsenical spray when buls begin to open.

Buffalo tree-hopper : $\Lambda$ sumall greenish insect abont one-third of an inch long, that punctures the twigs, causing a peculiar scarred appearance. Remedy : Cut off the injured twigs and burn.

Colling moth: 'lis estimated thitt one-latf of Anerica's apple crop is anmatly rmined by the conling moth. This is the pest that causes " wormy applecores." The moth seldom flies except at night, and therefore few fruit-growers lave ever seen one. About the tine that the blossoms are falling, this moth appears and gltes its eggs on or near the niniature apples. In about a week these eggs hatch, 
and, as a rule, eacli little apple worm soon finds its way directly into the upright, open, cup-like blossom end on top of an apple. Here it hides and feeds for several clays-then it bores its way into the apple to the core. The time to fight this pest is when it is feeding on the ontside of the apple, in the little cuplike crallc. $\Lambda$ drop or two of poison then applied will quickly kill the worm and thus save the apple; whereas if the figlit is delayed $11 n$ til it has really enter 'd the apple, no ontward application of poison

13y can affect it. "The falling of the blossoms

Top is the signal to begin spraying; the closing of the calyx lobes a week or ta'o later is the signal to stop spraying." "The Borleamx-arsenical spray is excellent for this

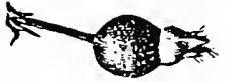

"stop SP'RAYING"

“BEGIN SPRAYING" purpose. Two applications-a week apart
-are antvised. Banding the trees, and promptly destroying all windfall apples, are measures which are also of lielp.

Canker worm : This "looping" or "measuring" s.terpillar feeds upon the foliage and is often very destructive. Renedies : Sticky bands of tar, printers' ink, or fly-paper, placed around each tree trunk in early spring to prevent the ascent of the egg-laying moths; all arsenical spray all over trees where worms have hatched.

Curculio: $\Lambda$ lmmp-backed beetle about an eightlı of an incl long (related to the plum curculio, but with a longer snont) which sometimes stings young apples. Remerly : $\Lambda$ rsenical spray. 
Leaf roller, leaf crmmpler, and leaf skeletonizer: These three pests can be killed with an arsenical spray.

Scale lice : San Jose, oyster-shell, and scurfy. See Chapter VIII for remedies.

'Tent-caterpillar: The well-known "nest" worm fomm on trees in early smmmer. Remedies: 'Tie a piece of cloth aromnd one end of a long stick, saturate the cloth with kerosene, ignite, and with this torch (puickly burn eacli silky tent of worms; do this in early morning or just before niglitfall, so as to be sure that all the worms are "at liome"; an arsenical spray is also lielpful.

Woolly aphis: There are two forms of this insect; one attacks the roots, as toll in Cliapter III; the other occurs in misses of white, woolly substince on the lintbs and trunks. Beneath each woolly mass will be fonnd a number of yellowish lice. Remedies: Kerosene elmulsion, tobacco solntion, or scalding lot water.

P'Rincipat, l'ungous l'ests. - l'owilery millew: Whitish blotches sometimes fomm, about miclsmmmer, on terminal shoots and leaves, which soon spread over most of the new growth. Remerly: Bordenux nixture.

Rot: This trouble is also called "bitter rot," "ripe rot," "apple rot," etc.; it attacks the fruit before the ripening periol, cansing decayed brown spots; nsually the infected specimens drop to the ground, althongh some of then shrivel up and stay on the tree all winter, thus carrying the fungous spores to the next year's crop. Remedies : Destroy fallen frnit; remove 
and burn all mummied apples which stay on the trees in the fall ; spray witl the Bordeanx mixture early in the season. (Note: lliere is another form of rot whicl is called "pink rot." Borleanx is the renedy.)

Rust: A fungus which sometimes blisters the leaves with orange-colored spots, and which usually originates on ceclar trees. Remedlies: Spray or cut down any cellars which may be near the apple orchard; sprily the orchard with Bordeanx.

Scal): This is sometimes cilled "black spot"; it produces the well-known scibluy places npon apples; it also affects the new sloots and leaves, cansing black blotches thereon, - and of ten the early spring leaves are thus bliglited; young apples shrivel and drop from the tree; mature apples are serionsly disfigureal. Remerly : Bordeaux, several sprilyings at intervals of about two weeks, beginning lefore burls open.

'Twig blight: 'llis apple disease is similar in nature to the well-known "fire bliglit" of the pear; affected terminal twigs (inclucling leaves, flowers or fruit thereon) turn black or brown, and die. The only known remealy is to cut ont the diseised parts, and hurn. (See peir blight, Chiıpter XIII.) This tronble connes and goes, and is worse some years tlan others.

MISCELLANFous 'Troubles. - Chief among these are sun-scald (consult Chapter $I X)$, crown galls (Cliapter III), canker and collar rot. No very good remedies are known for the two last-mentioned troubles; they seem to be closely related to "twig" and "fire" blight ; for instance, a blighted twig will often canse a canker to form near its base. 
Canker is a fungous or bicterial trouble which causes critcked or sunken irregular cleut places to appeir on the bark or limbs, in crotclies, and sometimes in such form as practically to girclle small branches. Cuit out and burn such sunall branclies. If large cankers appear on trunk or main linbs, cut ont the diseaseal places with a sharp knife, swab ont and disinfect the wonuds witl corrosive sublimate solntion (one tablet dissolved in one pint of water), ancl, when dry, cover the places with thick leatl-indl-oil paint. Do this early in the season. Renew the paint eacl year until womuls heal. Disinfect kuife after sucl use. Remenuber that corrosive sublinate is poison.

Collar rot most often atticks King and Spitzenburg trees, and diseisel trees slionla be treated as advised for callker. (Note: 'lop-grafting these varieties on, sily, Spy stocks, would secure new trees less liable to this disease of the bark at the base of the trunk.)

$\Lambda$ WISF; "COMBINATION" SPRAYING SYSTEM.The np-to-rlate grower does not of ten consiller each inscet and fungons pest separately. No. Ile plans a spraying canluaign which pretty nearly hits tlen all (except borers, aphis, etc.). Ilere is a good system : First spraying, Bordeanx, in spring before leaf buds open ; second spraying (if bu1 worns, cauker wornus or curculios are abuu(laut), J3ordeanx-arsenical $111 \mathrm{ix}-$ ture, just bofore blossons open ; thiral spraying, Bordeanx-arsenical nixtnre immediately after blossons fall; fonrth, repeat same mixture at end of one week; Bordeaux alone, two weeks later, may make 
the fiftl application. (Note: Often, only the first, third and fourtlı sprayings are necessary. If linesulphur-salt spray is used in February or Marcl for San Jose, the first application of Bordeaux may be omittcl. Rentunber, line-sulplunr-salt is a fungicide as well as a scale killer.)

$\Lambda$ PPI,F BY-PRODUCTS. - Ihe poorer gracles of apples can of ten be advantageonsly ntilized in the making of jelly, marnialade, dried apples, and vinegar. With a hauld press abont two gallons of cider can be extracted froul a bushel of average apples; witi a power press it is possible to extract alnost twice as much. Jarrels for cirler vinegar slonlal be thoronglily cleaneil and scilderl ont. Fernentition is usually conpleted is from three to six weeks, at which time add a small quantity of mother of vinegar to linsten the vinegar process. Adnit air freely to the barrels, keep them in the warmest part of the cellar, and in less than a year you sionlal inive a supply of excellent vinegar.

REINVIgORATING AN OLD, NEglected 'ORCHARD.-Circunstances mily aiter cases, but in a general way I suggest the following plan : lirst, prune as directed for neglected trees (Cliapter $V_{1}$ ); then con1mence the "combination spraying system" reconnencled in this clinpter; look ont for borers, snuscallu, scale lice, etc.; scrape loose bark off from trunk and nuin linbs, and apply whitewash thereto (if line-sulplinr-salt spray is 11sed, whitewaslı will not be needed); pling up or paint all old wounds, first sawing off all old stulss (grafting wax makes a good plug for carities); plow the orcliarcl in spring-as sliallow as possible; never winl if you clo cnt a few roots; apply 

I'LATE $\mathrm{X}$

\section{MAIDEN'S BLUSH}

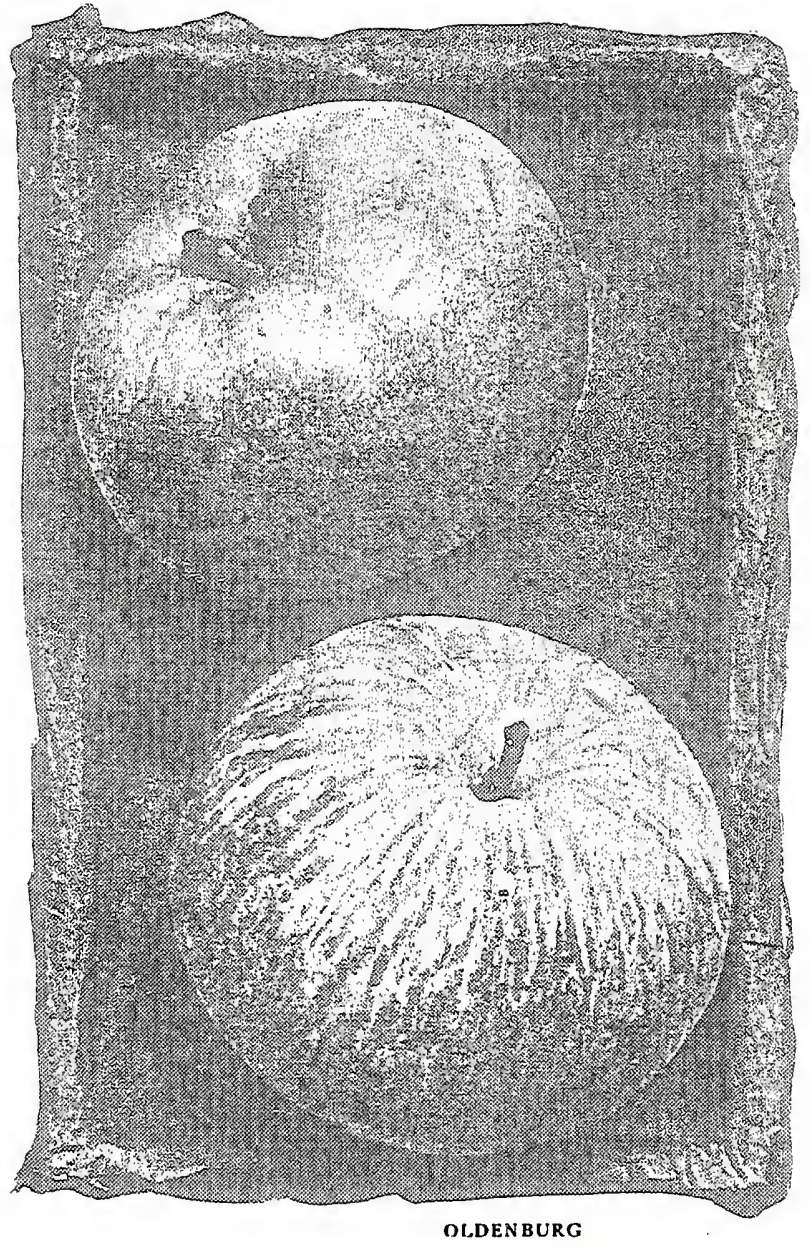


fertilizers, aul cultivate, regularly, as tolu in Cliapter VI ; sow cover crops ats tirected in Chitpter IX; contimue to prume, sprily, plow, fertilize, cultivate, etc., eacli following year.

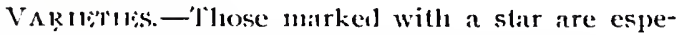
cially suited for commercial orcliards and market.

J., J. Judsem, Idalke, says that Jomalhan, Rome Heamty and Hen bavis are the sreatest favoriles, the state over, for comne.reial flimlalions.

1. C. Whitlen, Missongi, pins his fath le lluese enmmereial

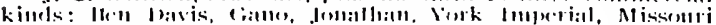

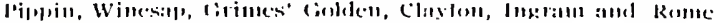
Jeanly:

W. 'l'. Vincembeller, Arkansas, wriles: Jior a list of market apples that I would plant int at1 orcharal of 1, tou trees, 1 leeg to stale tlat I womld nse Jlack ben l)avis, Jonallan, Grines' Golde'11 and King David, in edual (puantitics.

Jarm Jomrnal's "best sixlecu" hist of markel varictices from

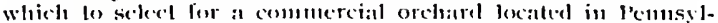

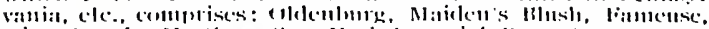

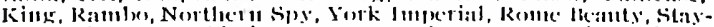

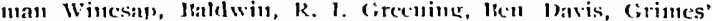
Golden, Sutlon Beauty, Sulwokchouse, Sunith's Cicler.

Dr. Clamberlain's favorite list of market varicties for Olio, is as follows: "lior sumumer, Red Astraclian, Ollewbure; for carly fall, Maiden's Jinslı; for late fall and winter, Jaldiwin, R. i. Greening, Seek-11e-furtlier, Jeck's I'leasant (short-lived

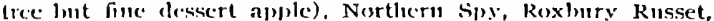

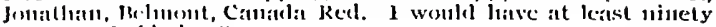
per ectut. Juhlivins."

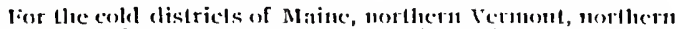

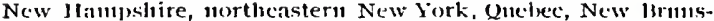
wick, cte., and the morthern peninsula of Michigan. the following varictics are sugrested hy lle governulunt pontulogist:

felofsky; *oldenlure; * Graveustciu; Wealthy; St. Jaw-

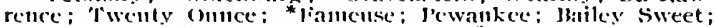
Melntosl1; Wolf River; folmatl sivect; Nortlett sts.

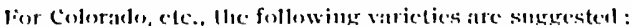

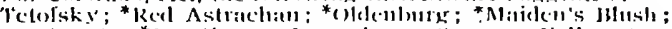
lailey Sweel; *Jenatlatu; J'cwatuee; Swatu; Jallawater;

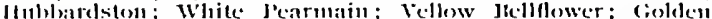
Russet: l'eck's I'leasant: *Winesap); Vellow 'Iratusparent; Jarly Harvest; Red June; Gravensten; Vealluy; Wolf River: *Grimes' Golklen; Northern Spy ; 'Tolman Swcet; ${ }^{*}$ M issouri ; *'Tounpkins King; Red Canada; Rhode Jsland Greening; ${ }^{*}$ Rome Beauty; Wagener; Wlite Pippin; Rall's Jannet. 
For Delawarc, sonthern New Jersey, Maryland, Virginia, West Virginia, sonthern Ohio, sonthern Indiana, Kentucky, Tennessee, and North Carolina, the following varieties are suggested :

Yellow Transparent ; Trenton Early ; *oldenburg; Primate : Red June; Gollen sweet; Yarly sirawberry; Fall pippin:

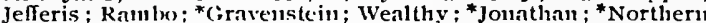

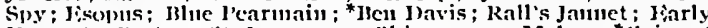
llarvest; lorter; St. Jawrence; Shiawassee; Melon; * Cirillics Golken: Newtown Spitzenlure; liallawater: "Wlite l'ippin; Arkansas (Mammoth I3lacktwig); *Stark; "York Imperial; *Stajunan Winesap; *Vellow Newtown.

For northern lllinois, Wisconsin, Minnesota, lowa, and Nebraska, the following varicties are suggested:

'Tetofsky ; Red Astrachan; * Oldenburg; Ked Stripe ; Golden Sweet; * Benonii; Charlantoff; Jorovinka; Porter; *Maiden's Blush: Alexancler; Dyer; Rambo; Jowell; Slitawassee: Yellow Transparent; Farly Harvest; Primate; Jefferis; Gravenstein; Fall Pippin; St. Jawrence; Wolf River; *Wealthy; Fanrense; Mclntoslı; 1,adies' Sweet: *Grimes' Golden ; West-

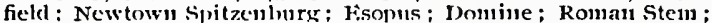
*White l'ippin ; Rome Beanty ; *Stark; Rall's Jannet; *Villow;

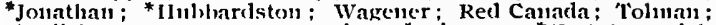
English Riusset; N. W. Greening; *Winesal); *York Inuerial.

For New York, Massadnusetts, Connecticut, southern Vermont, southeri New Jampshire, morthern New Jersey, Peninsylvania. northeru Indiana, northern Ohio, and the lower peninsula of Micligan, the following varieties are suggested:

Jarly llarvest; *Uldewhirg; folden Sweet; Red Strize; Sweet Bonglı; Jiarly Strawlerry; *Maiclen's I3lıslı; Red Astra-

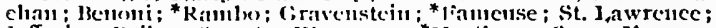
Jefferis: Bailey sweet: Wigener; *Northern Spy; Jisolus; * Ronle leanty; *llaldwin: *1ken l)avis: * Rhode Island Greening; Winesan; *York Juncrial; Iall I'ippin: Shiawassee; Jersey Sweet; Wealtlys; *Grimes' Golden; Smokehouse; *Sutton Beauty ; ${ }^{*}$ Smitlı's Cider ; Westfield; Newtown Spitzenburg; Red Canada; *Toupkius King ; Hubbardston ; Roxbury; *Stark.

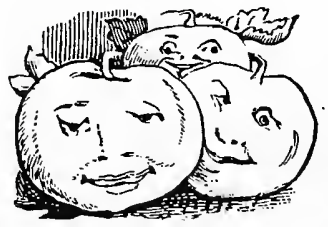

JOLLY GOOD FELLOWS 

PLATE XI

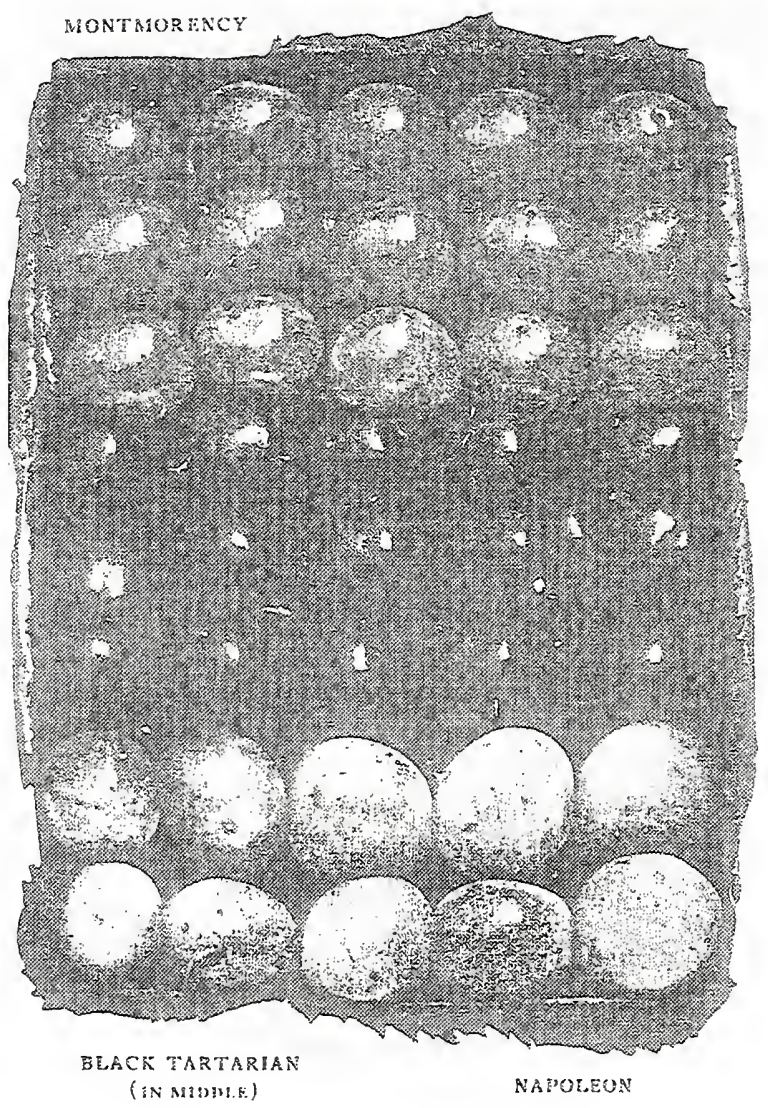




\section{Chapter Xil.}

\section{THIE CIIERRY.}

Plant enough cherries for both folks and hirds.-Viarmer vincent.

This delicions fruit came originally from lintope, and comprises two distinct species-sonr cherries and sweet cherries.

l'ropaga'tion. - Budling is the nsmal method. Common seenlings mate nsed for stocks, allhongh nurserymen commonly use imported stocks such as the Mahaleb or the Mazzaril. lor very cold climates the Mahaleb stock proves more hardy.

SELECTING NURSFRY TREES. - Cherries one or two years old from the lud, are abont right. Cloose mellimu-size trees. If yon can gret nubranclien sweet cherries, they are somewhiat easier to make live.

SorLs.-Cherry trees do best in a light soil, well drained, but not too dry; sandy, loamy or gravelly.

SpFcial, Cultrivatrion Rules. - Owing to the fact that the cherry matures its fruit so early in the season, cultivation shonla begin earlier and cease sooner than in the case of other tree fruits.

lark-burst, snn-scall, gumu: Cherries (especially sweet varieties), often grow so rapidly as to burst the bark at sone point or points on the trunk. 'Therefore, excessive pruning, cultivation or nitrogenous fertilizers should be disconraged. In fact, niany growers say that cultivation should cease two or three years after planting, and the gromml be seeded 
down permanently. 'This, of conrse, depends somewhit on climate, variety, and soil. In regard to sun-scald injury and preventive neasures, consult Chapter IX; for gum, see Cliapter XII.

VARIE'TIES WHICH ARE OFTEN SELF-STFRILE.S. W: Fletcher places three varieties in this list: Napoleon, Belle de Choisy, and Reine IIortense.

PrUning. - The less cherry trees are pruned the better. Of course, it is necessiry to cut back a tree at time of planting, and to guide it in the riglit path for the first two or three years. 'The frnit of the cherry is prodnced only on wood which is two or three years old.

PRINCIPAL, INSFCT I'ESTS. $-\Lambda$ plis (lice): $\Lambda$ ttack the leaves on encls of tencler young sloots. Reniedy: Tobacco solntion, applied early, before leaves curl.

Borers: 'The flat-lieaded cherry-tree borer is very mucli like the flat-lieaded apple-tree borer.

Curculio: The plum curculio often stings clierries, too, but the injured cherries are not so apt to drop off.

Clierry fruit-fly or maggot: $\Lambda$ fly which punctures the skin of the fruit, and deposits an egg which soon hatches into a sminll worn or niaggot. The curculio makes a crescent-sliaped puncture; this fly does not. Prof. Slingerland says: " Place a temporary wire netting around the trees and turn hens therein soon after the fruit is picked."

Leaf rollers: These pests feed on the lenves and roll them together for protection. Remerlies: Arsenical sprays; cut off and burn badly infested twigs. 
May beetle: 'This well-known "Jume bug" sonnetimes attacks the foliage at night. Arsenicil sprays.

Rose bug : See Chapter XII.

Slug: The ordinary pear-tree slug often feeds on the leaves of cherry trees.

San Jose scale lonse : Consult Chapter VIII.

Principat, liungous Pests.-Mlack kilot: Ditrk, knotty, wart-like bunclies upon twigs and brancies. Easily seen and recognized. Spreads if not promptly attended to. Renedy: Cut ont and burn all knots as soon as seen; cut well below the diseased parts (also, spray the trees with Bordeaux).

Brown rot: It canses decayed brownish places on, the fruit, quickly ruining it and rapidly spreating to adjacent cherries; infected specimens may drop to the ground, or they may slirivel up and stiy on the tree all winter, thus carrying the disease to next year's crop. Remedies: Destroy fallen fruit; remove and burn all mummied clierries found on the trees in the fall; spray with Bordeaux, several times, early in the season; pick the fruit promptly and early.

Leaf-blight or spot: Often called the "shot-liole fungus." Makes romnd spots on the leaves, which soon drop off. Remedy : 'l'wo or thiree early sprayings with Bordeallx.

lowilery millew: See Chapter $\mathrm{X}$.

Complete Spraýing System. - Properly and easily to treat most insects (except lice, borers, etc.), and all fungous pests, I suggest the following combined niethod: Just before buds open, apply Bordeauxarsenical mixture; give second spraying when fruit has set, nsing same mixture; two weeks later, 
Bordeanx. (Spccial note: If the trees receive a linesulplinr-salt treatment for Sin Jose in early spring, the first l3ordeanx application may be omitted.)

BIRD INJURY. - I wish that I were able to singgest a really satisfactory way to prevent birds from getting more than their share of cherries. The only practicable remedies seem to be: Eitlier put mosquito netting over a few trees, or plant enongh trees for birds, market and fanily. One or two nulberry trees help to attract birds away frow the cherries.

VARIETIES. - Those marked with a star are especially suited for market.

11. I. 1'rice, for Virgrinia, reconnucnds: Coe's Transparent; Early l'nrple: Windsor; Reine Ilortense ; *Montmorency ; Olivet.

J. I. Jlerlıst, Sparta, Wisconsin, recommends just one variety - liarly Richnond - as being profitalsle to plant in that cold clinate.

My friencl wilmer Atkinson's favorite list for Penusylvania, and sintilar clinates, is as follows: *13lack 'tartarian : *Vindsor Gov. Wood ; Downer's Jate ; I Farly Riclmond ; "Nontmorency.

Itdwatal J. Wickson reconnucuds for California, the followiug varietics: *IFurly l'urjlc (inigne: *Napoleon (oftell called Royal Ann"); *lewelling; * Black '1artarian; *California Advance; *Bing.

Benton Gebhart, a successful Micligan grower, says that he has lrad hest results with the following: *Early Richmond *Montmorency; *English Morello: *Brusseller Brante; sweet varieties-*Gov. Wood; *13lack Tartarian; *Windsor.

G. 11. Powell and 1. 11. Bailey, New York State (where there are many commercial clicrry otcharis), recommend these

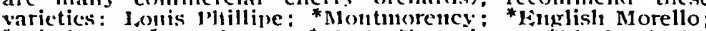
*IViulsor: *Napoleon; * llack Tartarian; *llack Eagle; * Mezel; * Roluert's Red lleart: * Downer's 1,ate Red: Gov. Wood; Coe's Transparent: lielle d'Orleans: Rockport; Kuight's Early Black; Yellow Spanish ; May Duke. 



\section{OI,DMIXON FREE}

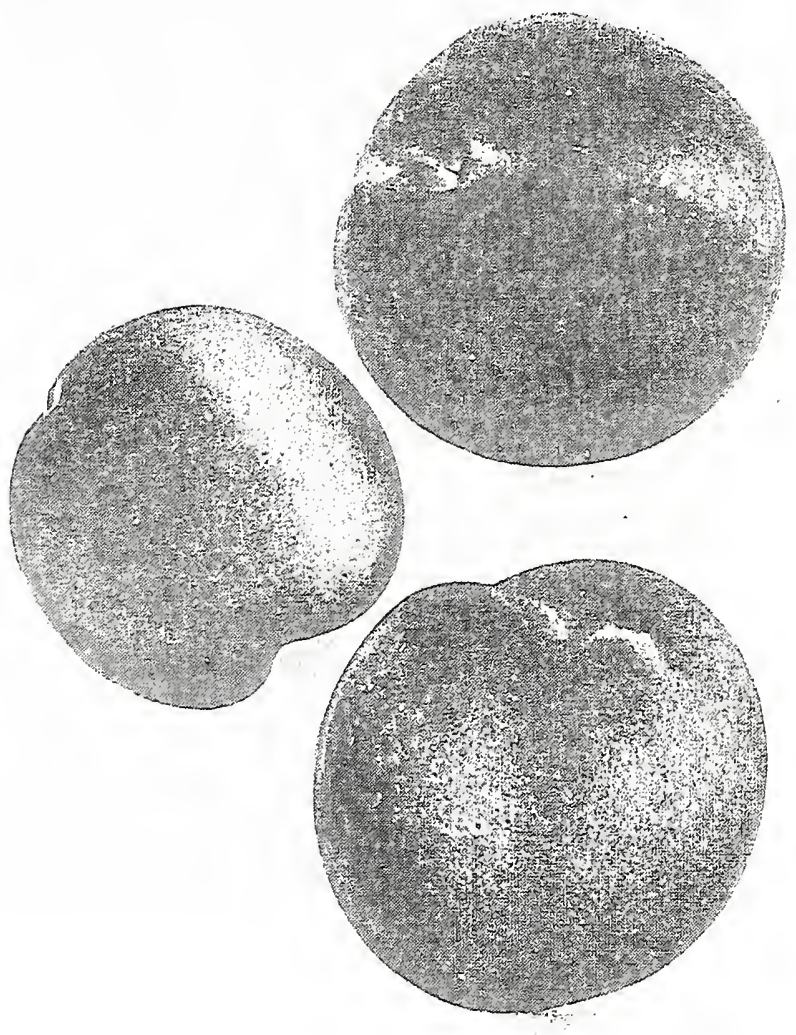

SALWAY

MOUNTAIN ROSE

(FRUIT NOT THINNEI) 


\section{CHAPTER XII.}

TIII P'IACII.

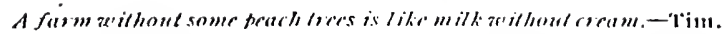

The peich is not a mative of $\Lambda$ mericil. Probably the peach originated in Chinit; from thence it went to l'ersia and to Jiurope.

Propagation. - Bul known varieties on to seedling peich stocks, close to the gromud. $\Lambda$ thrifty tree one year from the bud is the right size to set. When buying trees, choose medimm size, straight ones; let the

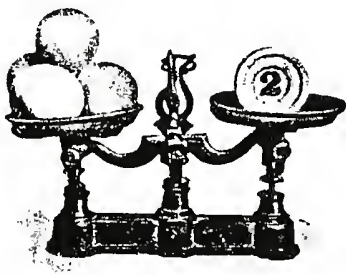

FOUR IIALF-IOUNU IBFAUTIES lig, overgrown fellows alone. (Note: I'lums are sometimes useil for stocks, if the peich orcharil must be planted on rather lieavy, damp soil.)

VARIETIFS WIICII ARE; OHIEN SHI R-STHRILE.Under this lieading S. W. Fletcher lists only one kind of peach, viz.-the Susquelıanna.

l'RUNING. - Of ail frmit trees the pench seems to neel the most trimming (the dwarf pear is a close second in this respect). Jiach seison the trees slould be pruned-cutting them back and thinning them ont, both. Cutting off one-itaif or two-thirds of the new growth each year, is not too much. Remember that the peach (unlike the 
apple, cherry, plum, and pear) produces its frnit on wool of the precelling yeir, - that is, on oneyear-old woorl.

Special Cultivation IInTs. - The peach, to be healthy and profitable, must be cultivated. In this it is unlike the pear, cherry, etc.,-which sometimes do fairly well in sod. Experienced peacl growers do not, as a rule, plow a bearing peacl orchard until after it lias blossomed. Why not? For the same reason that they of ten clioose a 11orth slope-to retari, so fat as is possible, the blossoming period with its liability to eirly frost injury. Remember thit no tree will die so quickly from "wet feet" as will the peach (unless it is the clierry).

PRINCIPAL InSFC'T I'ESTS. $-\Lambda$ phis (lice): See precedling chapter.

Borers: 'The peacli-tree borer is the most conmon pest in this line, althoirgh the flat-healed borers of the apple and cherry sometimes (not of ten) attack the peach. For remedies, see Chapter IX.

Curculio: The plum curculio often stings peaches.

Fruit-bark beetle: A small black beetle which bores tiny looles in to the bark of npper twigs and limbs, and then forms inner-bark burrows. 'This causes some of the infested branches to wither and die. Renedies: This beetle is n1ost apt to attack untlirifty trees; therefore, good cultivation, fertilization, prining, etc., are lielpful. Iromptly burn all cuttings, so that the larva within may be destroyed. Early sprayings with the Bordeanx-arsenical nixture. This insect is sometimes called the "pin borer."

San Jose scale louse : Consult Cliapter VIII. 
The snowy tree cricket sometimes punctures new wood ; cut off and burn such woorl. Rose clinfers or bugs occasionally attack frmit, etc. Knock them into pins of kerosene.

Principal liungous Pests. - Brown rot: See preceding chipter for description and remedies. Besides affecting the fruit (and sometimes the blossouns), this fungus of ten injures or kills the twigs, as well. The result is something like "twig blight," althongh the cause is different from the true twig blight of the apple, peir, etc. Thinning the fruit helps to prevent the spreal of the rot.

l.eaf-curl: 'This is, some seasons, a very serious tronble in many peich orchards. Shortly after the leaves come ont in the spring they begin to curl, soon become distorted and misshapen, and then fall off. Thus the tree becomes partially or wholly denuled of foliage, the immature fruit is likely to drop off, and the vitality of the tree is, of course, more or less injured in the attempt to perfect a second and

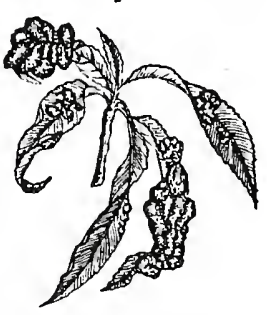

PEACH I.EAF-CURL later crop of leaves. Some varieties seenl more sulject to this tromble than others; and the disease is apt to be worse in a wet season. Renedy: linll-strength Bordeanx (or lime-sulphursalt) in spring bcfore buds sacell; when blossoms lave fallen, spray with laalf-strength Bordeaux; if necessary, repeat with half-strength Bordeaux two weeks later. 
Scab : Somewliat similar to apple scab. Bordeanx. Miscel.laneous 'Troubles. - Crown Gall : See Chapter III.

Ginil: Cansed by borers, bruises, and fungus. Common on peach, cherry and plum trees.

"I,ittle Peach" : Very little is known of this disease, and it is as yet common in only a few localities. The name is quite expressive of the symptoms; the fruit remains sulill and tomgli, the tree scens unhealthy, the leaves seen smaller than is natural, and finally the tree dies. The disease spreals from one tree to another. 'The only known remeily is to pull ont the infected trees at once, and burn then.

I'each "rosette" is a eliscase of the peacli in the sonthern stutes. Its effects on the tree are similir to those of yellows, and, like that disease, it is to be controlled only by the destruction of affected trees.

Sul1-scald: Consult Chapter IX. Sonte folks cill this trouble "frost-crack" when it occnrs dnring freezing weather.

"Sun-scorch" of foliage sometimes occurs during a 1routl, or when liot, lry winds blow. Regular cultivation is a partial preventive of sun-scorcli.

"Yellows": 'This is probably the nost serions foe that the peach grower has to contend with, - unless it be the San Jose scale lonse. It is a conmunicable disease ; it is always fatal within a few years; and it attacks hoth oll and young trees, and seemingly ins an especial fonluess for liealthy, vigorons trees. No cure is known, and the exact nature of the lisease has not yet been determined. In bearing trees the premature ripening of the fruit is one of the first 
indications of the presence of "yellows," silys 13. O. Longyear. Such fruits are also highly colored, possessing red spots and streaks which often extend from the surface to the pit, the fleslr being marbled and streaked with red. 'The buls formed during the sumumer, for growth the next season, are also sometimes preniaturely unfolded. But the most cliaracteristic feature is the growtl of bunches of slender, twiggy branclies dur-

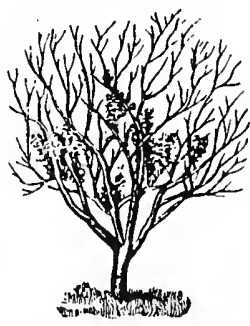

CAsF of "Yellows" ing the smmmer and antmun, from the crotclies and upon the older brancies. These wiry shoots hear narrow sickly leaves of a yellow color, ancl, being produced in clusters, give a cluaracteristic appearance to infectenl trees. "Yellows" litws, requiring the prompt destruction and lurning of infected trees, are strictly enforcerl in most peach locilities, and in this way the clisense has, of bite years, been successfully lield in clieck.

Comproirls SPRAying Systrim.-A combination system for fungi and most insects wonld be abont as follows : First spray, fiill-strength Bordeaux-arsenical mixture just before buds swell; second spray, after blossons fall and fruit has set, half-strength Bordeinx and arsenate of lead ; third spray, hilf-strength Borlenux-arsenate when fruit is lialf grown; if rot threatens fruit, repent half-strength Bordeanx spray, one or more times, at intervals of abont ten days or two weeks. (Special note: If the trees receive a 
lime-sulplunr-salt treatnent for Siln Jose in early spring, the first Bordeanx application will not be needed. But if fruit-bark beetles or curculios are abundant, it may pay to put some arsenate of lead in the linue-sulphur-salt spray.)

VARI1:ril:s.-Iliose marked witlı a star are especially suiterl for mirket.

K. 13. Wilkerson, a prominent Missonti grower, gives this list: Anselen; Jeath Cling; Crawford's Jarly; *Crawford's Late: Stu111p; *Crosby; *Champion; *Jilberta; *Wonderful; Triuinph.

Wilner Atkinson's farotite list is: Monntain Rose: Chatnpion: * Monre's lavorite: *Recve's Javorite: *Stmmulle world; *Fillicrta : *Crawford's 1 ate: Ward's Jate; Cliair's Choice; Globe; * Siliock Jirce.

George ' 2 . J'owell, for a commereial orchard in New York,

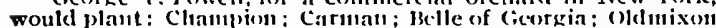
Free; Stump; Fox seedling. The list ninglit necol noxlif ying somewhat, according to the Jocation in the state.

For very cold climates, IIill's Chili, Channion and Crosby are perluass the niost hardy variety. But tl:e only sure way of growing a fantily supply of peaclics in such localities, is to "lay down "the trees encli fail, and cower thew over witli enrll, lcaves, straw, or ciller protection. Silcli trces slionlel be traincel flatsliaped. Cut the rouls ont onc side: theil pull the tree to the ground and stake it llicere. In the: spiring, riglit it; put the cartl back ill place; ferlitize, cultivate, cte.

J. N. Stearns, a prominesit western Michigan grower, writes : -If I were to piant another conmercial peach orchard of, say, 1,000 trees, I shonld set 250 Kalan11azoo, 250 Golcle11 Drop, 250 Smock and 250 Salway. 'These sorts hine bronglit nie nore money, for the last twenty-five years, than any others. Eilberta is too turreliable. Golden Drop slionld be severely pruned and thinnerl. (l'lense nole that this sincessful peach grower includes no white-flesh variclics in his list. Many markets and buyers prefer yellow-flesli peaclies.-J. B.)

J. Fr. IIale, the famous peach grower who has enormous orcharels in Connceticut and Georcia, writes that his favorite list for a succession fronl early to late in Con11ecticut, is as follows: *Greensiboro: *Vadtlell; *Carman; *IIiley; *Chanpion. *Belle of Georgia; *Iillerla; *Chair's Choice; *Steven's. Cint out Chair's Clicice and Stcren's, and the list is a "crean one" for Georgia, aclis Mir. IIale in his letter. ('The peach crop nust be gathered promptly when ripe, or loss resitlts therefore, in large orcharcls, planting varietics which ripen in succession through a long seasoin is higlily desirable and essential.-J. B.) 

PLATE XIII

SHELDON

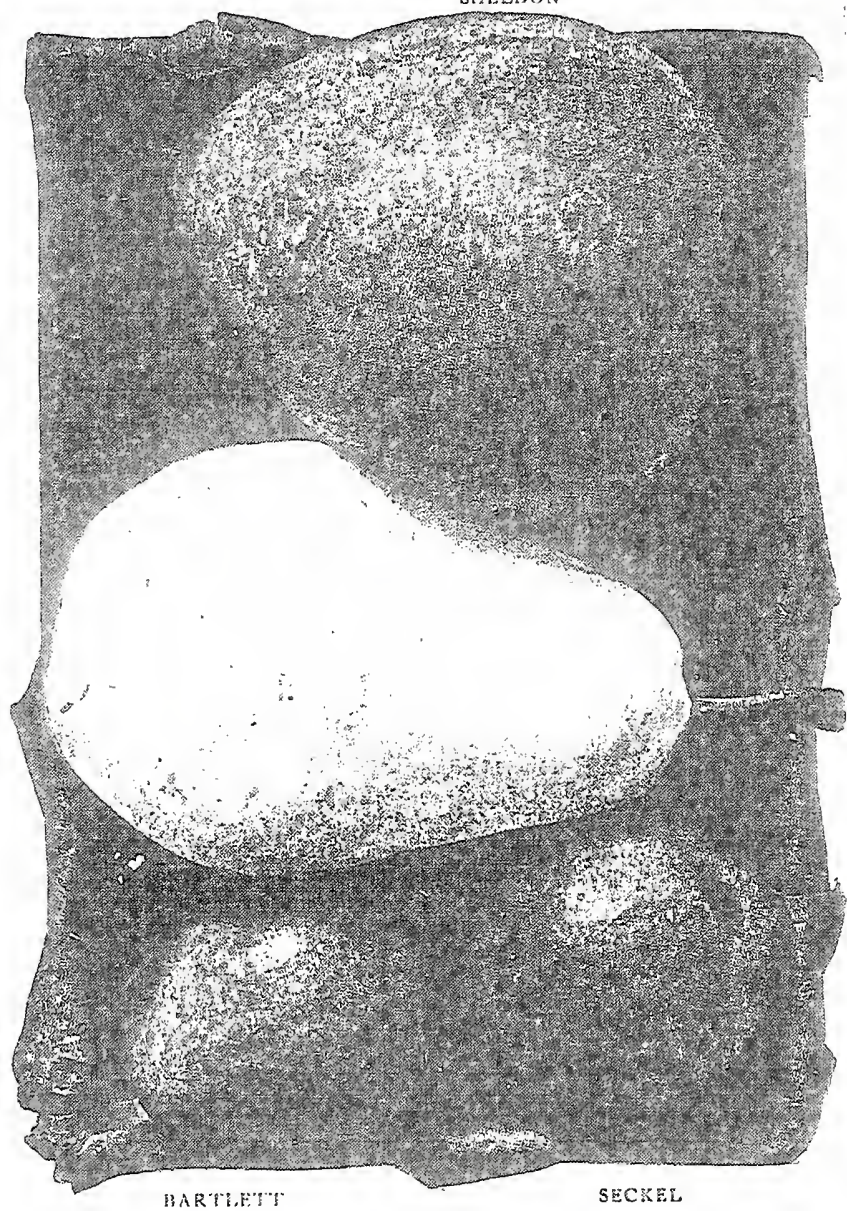

(IN RIMURE) 


\section{CHAP'TER XIII.}

III: PI:AR.

There's money in peras for the mall whe know's hom to get it out.

liver since this comutry wis first settled, pears from linropean stock have been grown here. 'They thrive especially well in the castern, central aml far western stittes, and less well in the somllern and pratirie states. Wherever the clinitle is very cold or

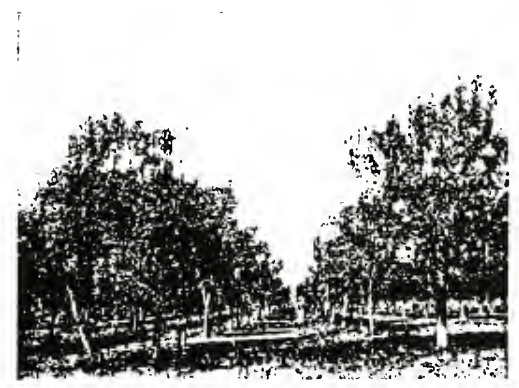

A TORTY-ACRI PI:AK ORCHAKI

very hot, there commercial pear cinlture lecomes Interertin or minstistanelory.

Prophan'son. - Stimularil pears are budiled or grafted on seelling peitr stocks, at a point near the crown. Nurserymen usually import seedling pear stocks from France, but it is not difficult to grow 
seedlings for one's own use. When buying nursery trees for setting, clioose medimm-size, straight, lowheaded, two-yeit-olds.

Sort.S. - The ideal pear soil is a rather heavy clayloau, with a well-rlrained subsoil. Ileavy clay does very well if the underlrainage is sufficient. Liglit or samly soils are not so good for this fruit.

VARIETIIS WHICH ARE OFTEN SELF-STERILE.S. W. Fletclier, of the Cormell, N. Y., Ixxperiment Station, gives this list: "1)uclıess; 13:urtlett; Clapp; Idaho ; Kieffer; Nelis." (Moral: Don't set solid, large lilocks of any one of these varieties, - nor of any other kinll.)

I'RUNING. - Cut back and thin ont, moderately, eacli seasont. N/way's cut back to a bull or a brancli, so as not to leave a stub). P'runing tools which are used on blighted trees, slowld be disinfected hefore bcing used again. 'llie pear prodnces its fruit on fruit spurs or wool severil years oll.

Special Culitural Jirlictions. - loo much cultivation is often dangerons to pear trees (see firebliglit). After a new orcliard has male a good growth for several years, it is often alvisable to seed down the land (permanently or temporarily), so as to stop excessive woul growth. I.ikewise, it is usnally prudent to stop cultivation carlier in the seatson than is customary with other trees (this plan-with an early-sown cover-crop - will often do away with the necessity of seeding down the orchard). The sane caution cxtends to fertilizers. Too nucl nitrogen meitus ton much wool growth; therefore nse nore potash ant phosplooric aciol, and less stalle mannre. 
The safest source of nitrogen supply is from occasional nitrogenons cover crops.

SUn-SCALD.-See Chapter IX.

PRINCIPAL INSEC'T l'HS'rs. - Borers: 'The true pear-tree borer is something like the peach-tree borer, only smiller and seldom so tronblesomely numerons. The romd-heated and fat-headed apple-tree horers also attack pear trees sometimes. See Cliapter IX.

Codling moth: Often attacks pears as well as apples. Consult Chister $\mathrm{X}$ for description and remedies.

Mirlge : $\Lambda$ sulall, grayish, long-legged fly which early in spring deposits its eggs insille the pear blossons. The eggs rapidly liatcli into tiny worms which enter the balny fruits and feed npon then, cilusing thent to stop growing or to becone misshitipen. During the summer these worms leave the fruit, fall to the gromul, enter therein, and make cocoons. Remedies: Spriys seen of little acconnt in figliting this pest. 'line best remedy I have seen suggested, is to apply about 1,000 pounds of kininit, per acre, to the infested orchard grominl in Junc. This potasli salt (it's a good fertilizer) is dissolved by rains, soaks into the ground, and kills the larvae.

Oyster-sliell bark louse : Sometimes attacks pears as well as apples. For remedies, consult Chapter VIII.

Pcit-leal mite or "blister": $\Lambda$ minute spicler-like insect which infests leaves early in the season, cansing blisters or gitls thereon,-redilish in color at first, gradually turning to a dark brown later in the sumuer. Remedies: Spriying the leaves does little good. But, as the insects hilernate on the tree bark, I think that the lime-sılphur-salt spray, applied before buds swell, would kill uites, scalc lice, and fungus. 
Pear-tree psylla: A tiny, jumping louse, yellowish in color, that attacks tender leaves and shoots, causing them to clroop and exncle sip or honey lew,-which condition soon attracts flies and ants to the feast. Entire orchirrls have sometimes been rnined, in a few years, by this pest. Remedies: Lime-sulphur-salt, or kerosene enmlsion, sprayed on the trees early in spring before buls swell ; followed by tobacco solution sprays in May or June.

San Jose scale louse: See Chapter VIII.

Scurfy scale lonse: See Clapter VIII.

Sling: 'The pear-tree sling is abont lalf an inclı, or less, in length when full grown; darkish color; slimy appearance. It eats the upper portion of leaves. This pest connes froni eggrs linicl by a black fly. There are two brools of the slings, - one in late June or early July, and another in Angust. Remedies: $\Lambda$ lnost any of the standaril spries's will kill slugs; in fact, they are very easily destroyent. $A$ simple renedly wonld be an onnce of fresh white hellebore dissolved in three gallons of water and sprayed on leaves when slings are there. Or arsenite of lead wonld do. Or, fine dry road-clust or air-slakenl lime, thrown or blown into the trees, will kill every slug it covers.

PRINCIPAL, I'Ungous l'ESTS.- I,eaf-blight: This very common and serions disease produces, on the leaves in the spring, redhlish spots; these gradually enlarge and turn brown, until all or a large part of each affected leaf appears dark and dead. Badly injured leaves soon drop off, and in this way the trees may lose most or all of their foliage - which gives them a bacl sethack. The fungus also attacks 
stems and fruit. It produces ngly, hard, scabbylooking places on the fruit, frequently cansing it to crack open. Remerly: Spray the trees with ]3orleanx before blossoms open; repeat, after blossonus have fallen; repeit, once or twice more, at intervals of two or three weeks. 'This trouble slionld not be confused with the disease called pear or "fire" blight, which attacks the limbs of trees.

Scab: Scably fruit is usually caused by leaf bliglit. A very similar (lisease-apple scal-may attack pears.

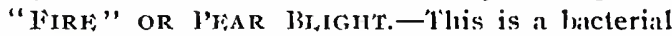
discase whicl injures or kills thousimuls of trees every year. It is to the pear orchard what the "yellows" is to the peach orchard-a deadly, relentless, not thoronghly masterenl, enemy. Whatever it tomches it blackens and "lurns,"-leaves, hlossoms, frnit and branches wither at its approach. It sometimes walks down a pear tree limb at the rate of from one to twelve inclies a dily ; usially only two or three inclies, or less. One can easily recognize the lisease. Watch the trees carefully during the growing season, and amputate attacked limbs at once. Irave a bottle of alcohol, ancl dip the tool in it after each amputition; it kills the hlight germs that will cling to any implement and which may infect the next tree that is treated. Nlways cut wcll bclow the affected part of branch. Burn all cuttings, promptly. This disease is more apt to attack fast-growing than slow-growing trees, therefore an inportant part of the treatment is to avoid a toostimulating methoof of fertilization and cultivation.

Combinatron Spraying SyStem.-The hest system yet devised for most insect and fungons troubles, 
is as follows: Spray trees just before blossoms open, with Bordeatux; after blossons litve fallen, Bordeanxarsenical mixture; two or three weeks later, Bordeaux; if season is wet and leaf-blight prevalent, repeat Bordeanx two weeks later. (Special note: If scale lice are present, or pear-leaf mite, or psylla, begin spraying operations by applying lime-sulphursith very eirly in the spring hefore buds swell. And, for psylla, don't forget the later, special, tobacco sprayings previonsly atrised in this chapter.)

VARIETIES. - Ihose markel witl a star are especially suiteul for market.

M. J. Ciraham, an Jowa fruit-grower, has had hest snecess with *1,ougworth; *Kicflet; *Warner.

Jor Virginia, II. I. J'rice recommends: Sumuer Doyense; Rose; Clajp:; *Jartletl; Jawrelice: Slieldon.

For Illinois, just threc commercial varietics are reconmended by R. O. Grahait!: *Kieller; *Garber: *Duchess.

For the sontheru stales-Mississippi, Alabama, ele. -W $\mathbf{H}$. Ragan recommends: * Kic.fer; 1,e Conte; Garber : Archangel.

For California, 1:. J.WVickson recommends: ${ }^{*}$ Clapp: ${ }^{*}$ Connice : *Anjon; *Clairgcan; *13artlett; *liaster; *P. 13arry; *Winter Nelis ; etc.

Wilner Atkinson suggests for Peunsylvania, etc.: Manuing's Itlizabetlı; *1fowell ; *llartlett: *Seckel ; Dana's Hovey; 1,awrence; $\Lambda$ njon; Duchess : ${ }^{*}$ Kiefler; Winter Nelis.

I1. R. Circen, "successful Miclsignu grower, writes: Jf 1 were

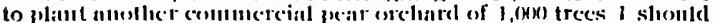

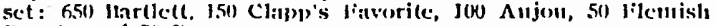
Beauty and 50 J3ose.

For Olıio, New Vork, Intiana, Comnecticut, elc.-Pomologist Ragall suggests : *llose: *Kiefler; ${ }^{*}$ Anjou : *1Bartlett; *1lowell ; Lawrence; Sheldon: *Bonssock: Clapp; Brandywine; *Seckel; *Duchess: *Lonise Bonme; Winter Nelis; and several other kinds.

For cold districts - Maine, morthern Vermont, Wisconsin, Minmesota, etc.-Ponologist W. 11. Ragan suggests the following: Vermont Icanty ; Flemish licauty; Wilder Jarly : *Bessemianka. (At the hest, pear culture is prccations in very cold climates. lianking earth high up aroumd tree trunks and holding it in place with boards, cluring the winter, is a great help.-J. B.) 



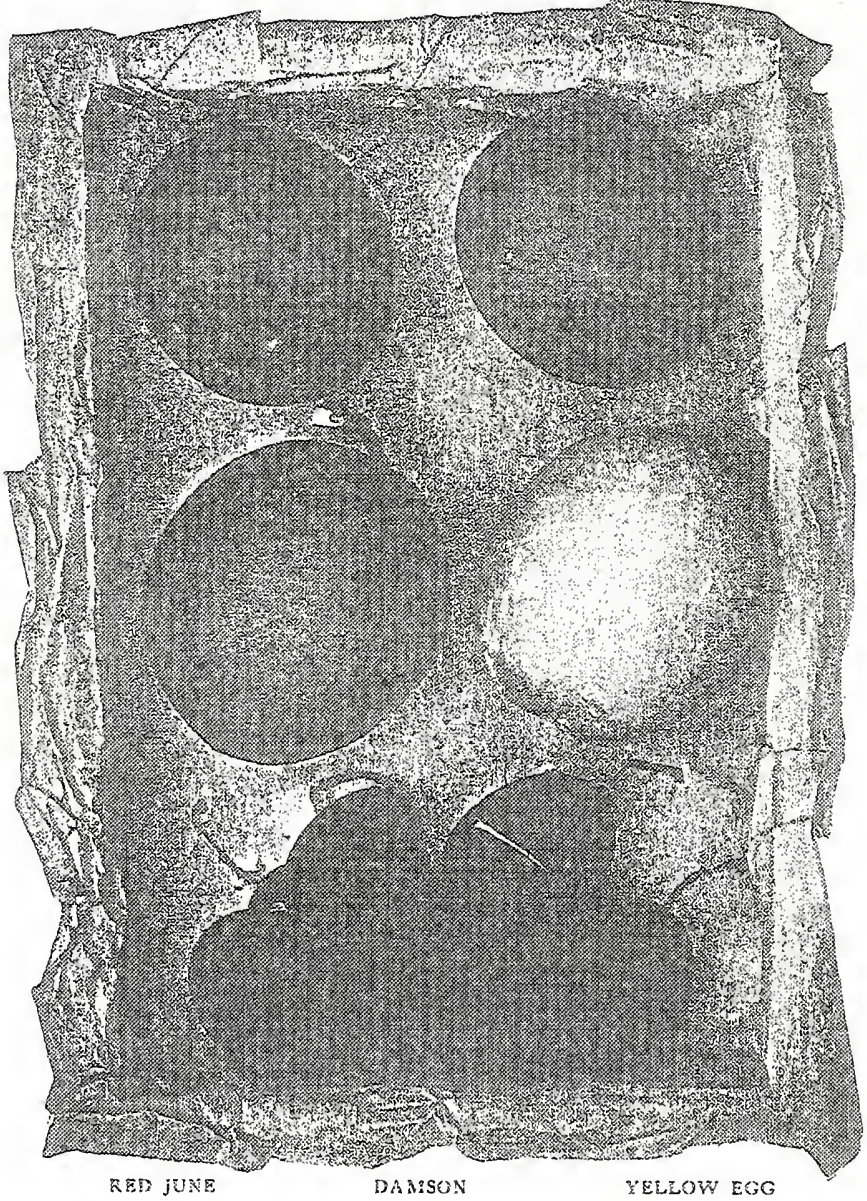


CHAPTER XIV.

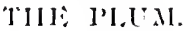

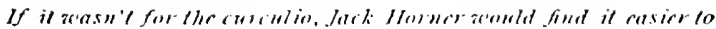

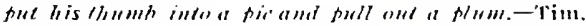

Generally speaking, plum eulture comprises several types or classes, viz.-I Inropean (I'runus douncstica); Japanese (Prumus trifforu) ; American (J'muns \& Iminicuna; J'runus hortulana), comprising Mild (ioose and similar native varicties; and l'rumus (birasa comprising the Chickasaw native types of our somtlern states. One or wo other types are not of sufficient importance to mention here.

I'ROPAGAron.- bumlingr is the common methonl, on seelling phnn stocks. These may he grown at home. Nurserymen, however, generally nse Myrobalan, Narianna, or other injorted plunn stocks, becanse it is not easy to secure sufficient seet for extensive planting. P'lums are sometimes burlated on seelling feach stocks, - particulary in the semth and for alry, sandy locations. Americana varieties usually do best if bulted on their own seerllings.

SHIFCOTING NURSERY TREkS. - Two-year-old trees are alomt right. liast-growing varieties are sometimes rearly for planting when only one year old from the lunl.

Sort,s.-I'lums do well alunost anywhere, - if the gronnd is not too wet. This fruit, lowever, will stand much more moisture than the peacli or clierry. (107) 
A clay-loan, rather moist but without stagnant subsoil water, would be icleal for the Entropean and native varieties. The Japanese kinds do very well on a lighter soil.

VARIETIES WhICH ARE OFTEN SELF-STERILE.S. W. Fletcher says nuder this lieading in Bulletin 181, Cornell 1ixperinent Station: "Coe's Golden Drop, Firench P'rune, Italian I'rune, Kelsey, Miner, Marianna, Ogon, I'each I'lu11, Satsun1a, Wild Goose, and (according to Wangl and Kerr) all other varieties of native pluns except Robinson."

I'RUNING.-Clie plinil recpinires more pruning than the clierry, and not so mucli as the peacli. Upriglitgrowing varieties recunire one style of pruning; sprawling kincls (like Burbank) require another. The trees may have a central leader, or be trained in the open-centre, vase-like style. Some varieties require nore cutting-lack than others. Stucly your trees. Plinı fruits, like clierries, are mostly home on fruit spurs which are at least two years old.

Principal Insect Pests. - Aplis (lice): See Cliapter X.

Borers: 'The plin11-tree borer sometimes infests the base of minin linils and the npper part of trunk. The pencli-tree borer, etc., occasionally attacks plu111 trees.

Remerlies: See Cliapter 1X.

Curculio: $\Lambda$ tiny, hu1np-backed, flying insect (see illustration) which stings curculio the fruit sliortly after blossoming time.
(ENLARGED) deposits eggs therein. These soon liatcli into little grubs. Mlost of the stung fruit falls off the tree 
before ripe. 'The curculio is sometimes called the "I,ittle 'Turk," on acconnt of the crescent-slape trade mirk it leaves on fruit; in size, this insect is alont three-sixtecnths of an inch in length. Remerlies : Bordeanx-arsenical mixture sprilyed on trees just before blossoms open ; repeat the same after blossoms fall; repeat, once or twice nore, at intervals of a week. Destroy all fallen fruit. $A$ lso, a flock of clickens in a plum orcliarl is a great help. But the surest one remerly is the jarring process. Rigr up a cloth-covered frame (like an inverted nmbrella), nomnt it on wheels, and jar the curculios into it so they can be collected and killed (see pictnre). The jarring is best clone (anring the cool of early morning) by tapping the tree loriskly with a padiled, long-handled mallet. The insects, slnggish with coll or heavy with dew, drop into the frame below,

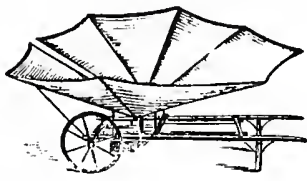
justear of flying away. This jarring process should be repeated every norning or so, as long as the curculios are plentiful.

Phm gonger: A small snout-beetle withont a hump on its back. Much like the curculio in its halsits and the effect on the fruit. It punctures the fruit, but does not make a crescent-sliape mark. Remerlies are the same as alvised for curculio.

Plum scale: Consult Chapter VIII.

San Jose scale louse : Consult Cliapter VIII.

I'RINCIPAL, Tiungous l'ESTS. - Black knot: See Chapter XI. 'These dark, warty-looking knots or bunches on branclies need prompt attention. 
Brown rot: Consnlt Chapter XI.

Leaf-blight or spot: Often called "shot-hole" fungus. See Chapter XI.

Plnm pockets: A fungons lisease which canses the fruit to becone distorted, enlarged and unhealthy ; finally it turus dark in color, becomes wrinkled, and drops off the tree. No pits are foumd in these diseased fruits. Remerlies: liarly sprayings with Bordeanx; prume the trees and cut off as much as possible of the wood whiclı bears diseased fruit.

Comination Spraying System. - For most insects (cxcept borers, lice, etc.), and all fungous pests, I suggest thitt you turn to Clapter XII and use the conplete system there atlvocited for peiches.

BARK - BURST, SUn-SCALD, GUM. - See Cliapters IX, XI and XII.

VARIETIES. - Those narked with a star are especially snited for market.

R. O. Gralıa!1, an Illituois phum grower, has had lest success with: *wild Goose; *Miner; *Wolf; *De Soto.

E. 1. Mason, Missouri, has hacl good success with: *Green Gage; *I,oulhard : *Niagara ; *Shipper's I'ride; *Damson ; etc.

For Alahama, Mississippi, etc., W. H. Ragan recommends: *Chabot; *Cumberland; *Golden Heanty; Red June; Yellow Transparent; *A Bunclance; *IBurbank; *Kelsey; etc.

For a commercinl orchard in New York, George T. Powell recommends: *Reine Clande: *Giant Prune; *I'eter's Yellow Gage; *Quackenboss; ${ }^{*}$ Iellewiferg: *German Prune.

For Pennsylvania, Ohio, Michigan, Connecticnt, ctc., Pomologist W. II. Ragan suggests: *Reine Clande(Bavay's Green Gage); *Bradshaw: *Coe's Golden Drop: *Danson; Jlack Dinmond: *German Prnne; *Grand Duke; Gueii; Imperial Gage; Yellow Egg: *Fellenberg (Italian Prume); *Lombard; *Quackenboss; etc. 



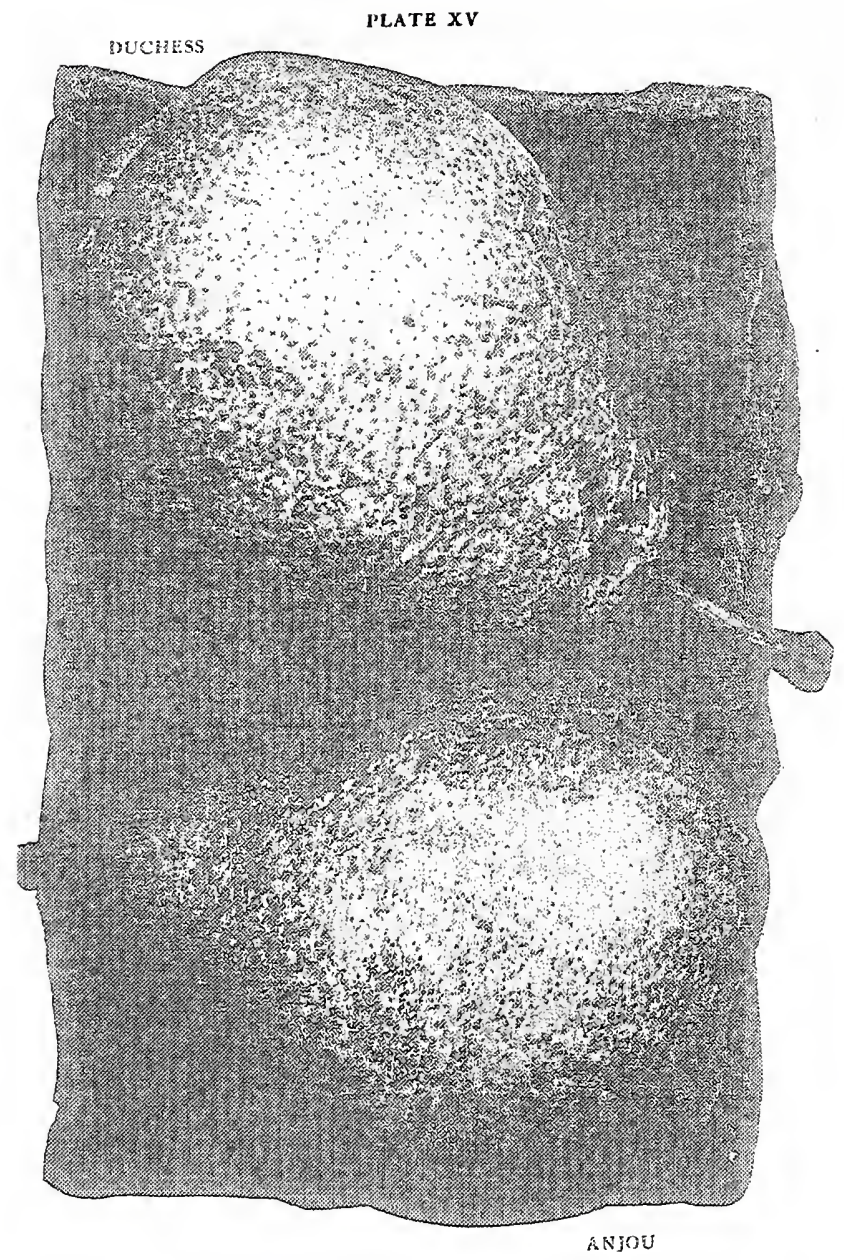




\section{Chapter XV.}

TIIE QUINCI: $\Lambda$ NI) HVARI' PI: $\Lambda R$.

They alen't big llees. bul there's a lot of them lo the ache.

Qunce culture, except in a small way, is not very popmlar. $\Lambda$ few commercial orchariss are to be foumd, here and there, and the fruit brings fair prices whenever the supply is not overlarge. $\Lambda$ s the fruit is practicilly meatable in a raw state, it is in demand only for camming, for marmalate, etc., ambl for flavoring preserves, etc. There is no more beantiful sight than a enince tree in hlossent. Jivery fimily shomla luave at least it few of the trees.

l'ROPACATION.-Any one of severil methorls maly be uscel: Bmlding, with quince seedlings for stock; grafting, on apple roots; latyering ; and making cuttings of ripencel wenl for plinting (in nursery rows) like currant or grape cuttings. Cintlings should be taken in the fall, in abont ten-juch lengrlis, tied in bundles, and stored away like scions until spring. Or they may be plinted in the fall, and protected witl mulch. I do not recomment lityering.

Cur,rurar, llints.-Qninces do best on a moist (but well nulderilrainel) diy-loim. Howerer, they will grow fairly well on almost any soil which is not too wet. 'llyorongl tillage is desirable. lint renember that these trees are sluallow rooted; do not plow too deep. Winter cover crops of some kind are essential; they lielp to keep the roots from frost 
injury. Pruning should be systentatic. Ileal back the new growth in the spring, or thin it ont, or both, -is may he repuired to minintain a slapely, wellbalanced tree. 'There is no sense in thinking that quinces must necessarily be straggling, misshapen buslies. Start with a straiglıt stem two feet high, have the liead open and well branclied,-and you can minke the tree as shapely as yon please. The fruit is prodnced on little slioots which grow in spring on wool that is at least two years old. Keep all suckers cut off from aromud the trunk.

I'RINCHPA, InSIOC'r AN1) I'Ungous P'ests. - The colling motlı, the fuince curculio, the roturl-lieatled apple-tree borer, the peir-tree sling and the pear-tree blister mite, all bother quince trees more or less. Remedies lave been given in preceling cliapters. Phere, tox, you will find hints abont leaf blight, rust, rol, twigr blight and fire blight,--all of which are wellknown encuics of the enince. The guince slonld be frequently sprilyed with the Bordeatux-arsenical mixture to keep trees and fruit healthy.

VARIETIES.-Comparatively few kinds are grown. Probably the best, for almost any locality, wonld be : Orange; Rea; Meech ; Clımmion.

\section{DWARI PIEAR.}

If properly grown and cared for, these trees are thrifty, prodnctive, long-lived and profitable. But if neglected, they are equilly sliort-lived and wortliless. I know of several dwarf-pear orchards that are now twenty to forty years old, whicl began bearing fruit wlien about fonr years old, and wlicli are still healthy 
and prodnctive. They latve rarely if ever missed a crop.

P'ROPACATION.- By bulling the pent on quince seedlings, dwarf-growing pear trees result. But the fruit is not dwarfed; on the contrary, it is musually large and fine, ancl the trees come into bearing mucls sooner than stanclaril pears.

Cultural Hints. - The best soil is a moist clay or clay-loam soil, thoronglily underdrained. Cultivation, fertilization, spraying, pruning, etc., nunst be

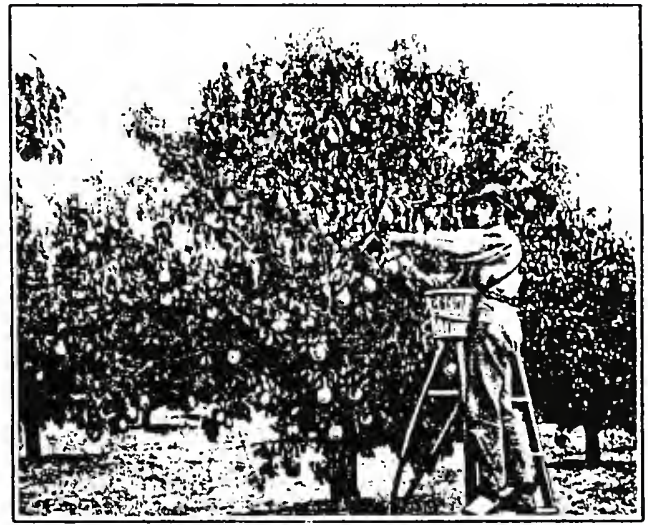

A MICHIGAN DWARF-PEAR ORCHARD

systematic and thorougl. Unlike the standard pear, the dwarf never does even "fairly well" in sod. When setting the trees, be sure to set them very deep,- - so that the bnd joint will be, say, six inches 
below the surface. If thus set the trees are less likely to break off at the joint (which is always a weak spot in dwarf pears); and, too, leep setting will ellconrage the pear wool to send ont some roots of its own, which adkls to the vigor and stability of the trees.

P'RUNING.- Dwarf pears need a great deal of trimming,- principally "cntting back." And they need it regularly eich year. Alout tivo-thircls or threequiarlers of the new growth should be cut off annually, - making the cut each tine to buts which point ontward, so as to broallen the trees. 'Iall, spindling trees have little " bearing surface," and, besides, such trees are more apt to blow down during heavy wind storms. (IVindbreaks are a specially gool thing for all (lwarf pears.)

INSHC'T AND liUngous linemies. - The same pests that trouble the stanthard pear, also bother the dwarf. Consult Cliapter XIII.

VARIVTIFs. - Only a few varieties of pears do especially well as diwitrfs.

I. $r$. Ycomans, whose dwarf-pear orcharel is aloout fifty ycars old, expresses a decided preference for the Duchess varicty.

I. H. Bailey, New York, says that the most successful kinds are Duchess, Anjou, Louise Bonne, Manning's Elizabeth aud Clairgeau.

C. S. Mills, a Michigan grower who has been renatkably.suc. cessful with a commercial dwarf-pear orchard, writes that if he were going to set another dwarf orchard today, he would plant six-tentlis *Duchess trees, tliree-tenths *Aujou, and one-tenth *1,onise 13onne. (1 do not think this list can be much improved for ally scction of the conntry.-J. B.) 

PLATE XVI

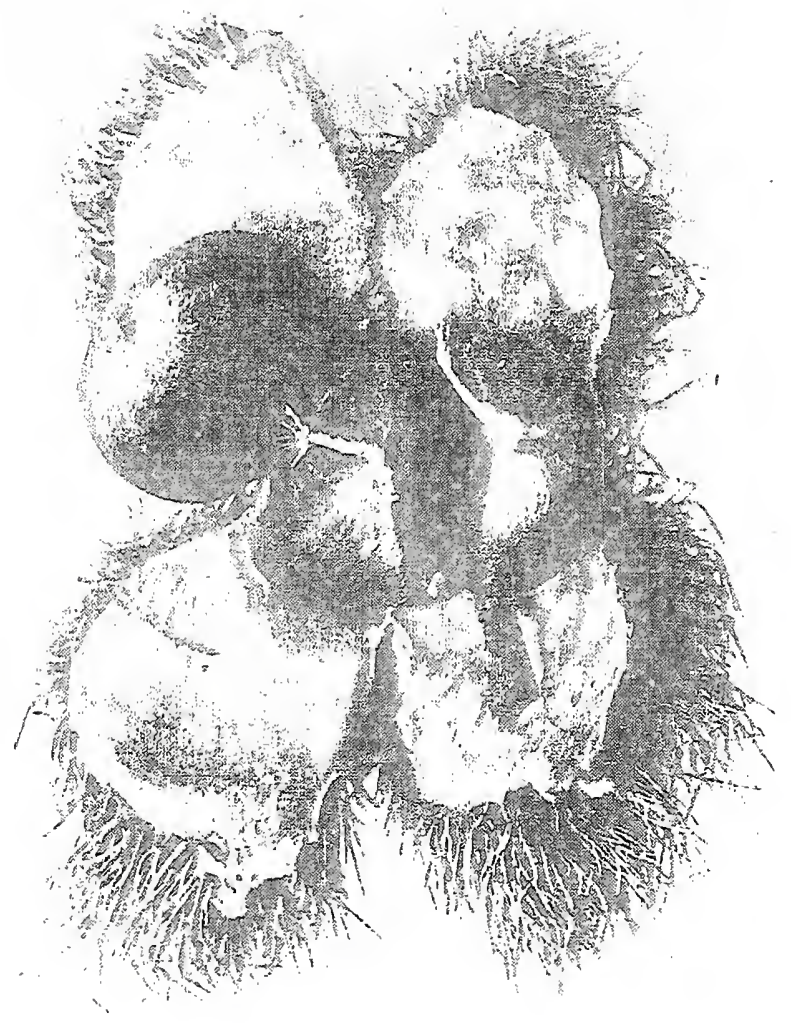

PARAGON CHESTNUTS 


\section{Chapter XVI.}

\section{NUT'TRIIIS.}

It seems to me that a good nut orchard is worth workmg for. - Tim.

The almond of commerce is the "soft shell" or "paper shell" type, but the variety is tor tender for siltisfactory orchiard growing in cold sections of onr

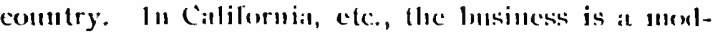
erate suceess. (locasional trees hatre hecu matele todo fairly well in northern and eastern states where the pench succeeds, but, without protection, suclı attempts are nucertinin. In the Sonth, the trees are apt to bloom very carly alul be nipped by spring frosts.

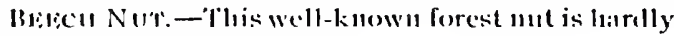
adapted to orchard planting.

BUTTERNUT AND BLACK WAINUT. -These, thongl very useful trees in their way, are scarcely in the orcharel class at the present tince 'l rees are nsilally propalgated by raising secellings from clusice nuts. 1 believe that mure of these trees shombl be plinted.

Cires'rnut. - Now we come to a species of mut which has distinct commercial possibilities for the

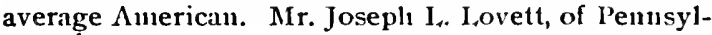
vania, now lias abont fifty acres on his own farm planted to improved cliestunts, - mostly laragons.

Mr. lovett plows his orchard each spring and then gives the soil regular cultivation until September first. No antumn or winter cover crop is planted, because sitch a growth would interfere with the 
finding of the nuts when they fall on the ground. The trees are set abont thirty feet apart each way; they begin to bear when quite young, and are not pruned or sprayed-nuless $j$ is to trim up an occasional branch that droops too near the ground. The red spicler leaves its mark on the foliage every season, but Mr. Lovett says that he "pays no attention" to this insect pest.

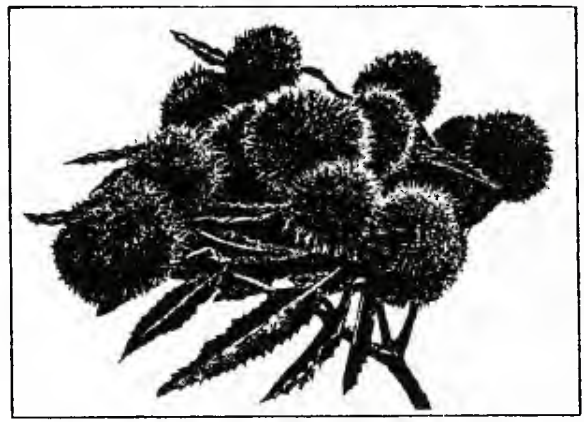

CLISTER OF PARACON CIIESTNUT BURS

The weeril has fomd its way into the lovett groves. liut not in forcc. There are no overlooked nuts, no stumps, no nulerbrusl, in which they can breed; the soil is frequently cultivated, all the nuts are picked up each season, and, consequently, the weevil has not proved to be a serious pest on this farm.

When harvesting the nuts, they are never picked, knocked or sliaken off. Mr. Lovett waits until Jack Frost loosens the crop. 
"Plow. a chestnut orchard deeply," silys Mr. lovett. "You should endeavor, in every way possible, to encourage a large, deep-growing root system. This is very important."

Sone nut-growers are taking cliestmut stmmp land, and are grafting Paragons, etc., on the spronts which come fron stmups. But Mr. Lovett says that this method has many objections.

Whip grafting is the nsual method of propagation, but the mion is not always successful. Nut grafting of any kind recuires great skill, and the average mitgrower hald better biny lis mut trees of a murseryman.

Cunguapin. $-\Lambda$ will, dwarf, luish-like viriety of cliestmut, of little commercial value.

Coconnut. - There are a few successful groves in sonthern I'loricla.

FiLBERT AND IIAZELnUt. - We call the American product "hazelnuts," and the imported kind "fillerts." Botanically they are botli Cory'lus. Commercially the culture of hilzelnuts has not been mucli of a success in this country in the East, and but slightly more so in California.

IIICKORY NuT. The shellbark hickory is as yet mainly known as a forest tree, but the time is no tonbt coming when sone of the finer varieties-Ilale's l'aper Sliell, for instance-wall be commercially planted. Ilickories (like black walmuts and butternuts) object to transplanting, and it is not eisy to propagate theil by grafting or budding; therefore they are usually grown from selected seed.

P'ECAN. - This lighly-esteened nut tree is a species of hickory indigenons on fertile, moist lowlands in 
Olino, Indiana, Iown, etc., and in many of the sonthern stites. Commercially, the culture of this nut is not likely to extend nuncl north of the Oliso and the l'otonilc rivers, silys I'rof. Balley. 'l'rees farther north are not apt to be very productive, and the nuts are sunaller in size. Seedling trees seldoun grow true to type; therefore grafted or budled trees are most desirable, $A$ splice crown-graft, on a pecin seedling stock, is one of the best recommencled propagation methods. But all methouls are clifficult; better buy trees of a nurseryman. Very little pruning is required after the tree is well started. Cultivation is very lielpful to a nut orcluarel. Paying crops slionda not be expected hefore ten or twelve years. Every locality his its favorite varieties, some of the best known being: Century; Van 1)ennan; Stuart; San Salua.

WALNUT.-Onr excellent native variety, the black walnut, has prerionsly been mentioned in this chapter, in connection with the butternut. The English walunt (also called " l'ersian" walnut and " Macleira" nnt) is not suited to cold climates, and commercially it is profitable, in this country, in practically but one state-Californial. Specimen trees can be grown, lowever, in Pennsylvania and sinilar clinuates. Another imported species - the Japan walunt - is often grown as an ornamental tree in the first and Nortl. It is luardy, bears its nuts in odd-looking clusters, but lias little commercial value. 

PLATE XVII

FIEMISE BEAUTY

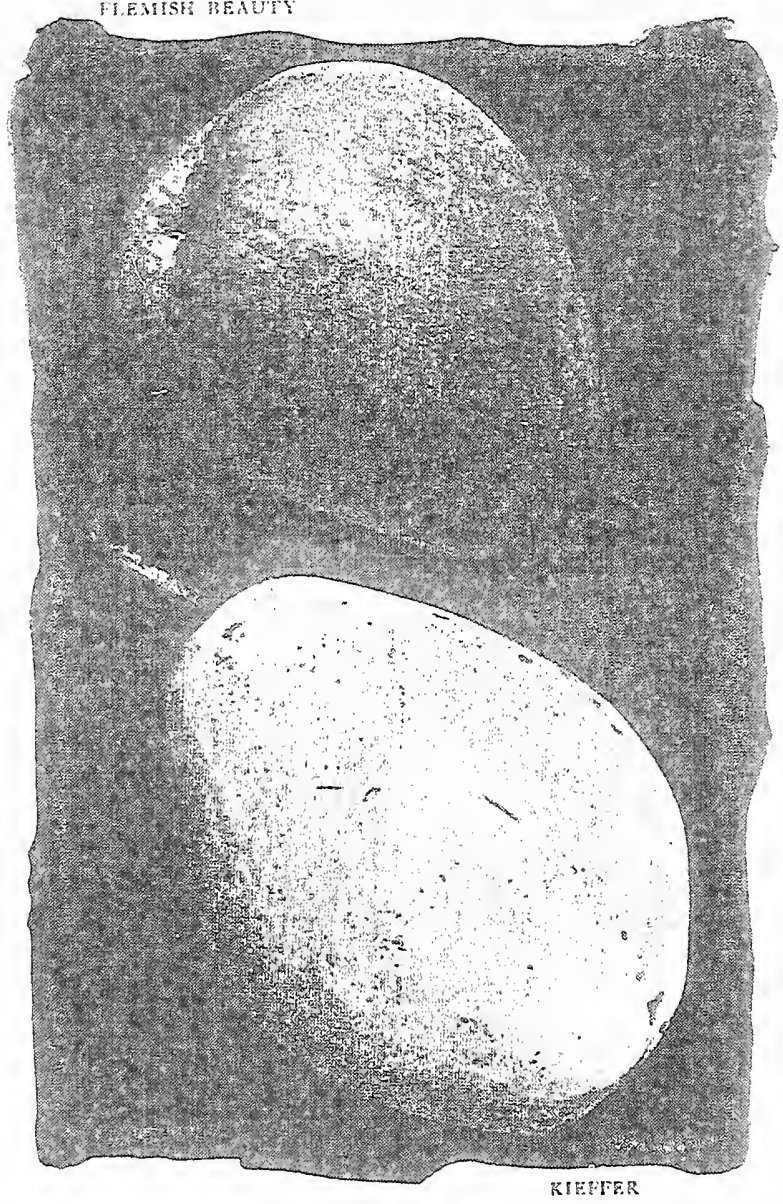




\section{Cilap'ri:R XVil.}

\section{CITRUS AN1I GIIIER JiRUIAS.}

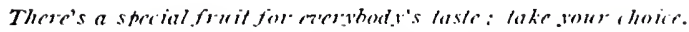

APRICo't. - Ylits delicions fruit is like botlo peach

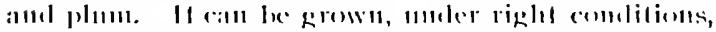
ats far nerth as westera New York, being alout as liardy as the peach and repuiring the sillle special contditions. Borers, rot and the curculio are the principal enenilies.

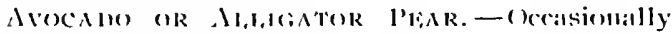
growa in sonthern lilorilit.

CI'TRON.-This is at small, lush-like tree whiclt bears a large, thick-rinded frnit which somewliat resembles a lemon in appearance. Grown to a norlerate extent in Iiloriıla and Ciliforniat, for preserves.

CRAll Appids. - The best-known varieties are: Ilyslon; Martha; Red silerian; 'lranscentent; Whitney; Yellow Siberian; etc. Iour insects, fungous tronbles, culture, etc., sce chipter on 'llue $\Lambda_{p}$ ple.

DATE PALM. - Occasional plantings of this noble tree are to be fonncl in liloricla, Nexico, Arizona, California, etc. 'The alry, even clinute of $\Lambda$ rimona will

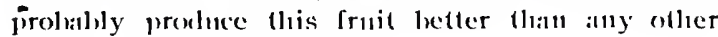
place in the Enited States.

Jisc.- lixcent on the lacific coast or in the far Soutl, fig trees are not commercially successful in this country. Bnt by bencling the trees down to the ground in the fall and covering thent, or by growing 
them in tubs which can be put in a cellar during the winter, it is quite possible to raise figs for hone use almost anywhere.

Guava.- - n attractive, refreshing fruit of the tropics. Snccessfully grown in sonthern Florida.

LEMON.-Grown connuercially in California, southern liloricla, etc. Propagation is usually by means of bucling on seedling stocks (orange seedlings are often use(1). 'The trees are generally set twenty to twenty-five feet apart. Cultivation should be given. Cut back and thin out the shoots each season. Whe lemon is more temier, as regaris frost, than the orange. Some of the lealling varieties are: Belatir; (ienen; 1mperial ; Sicily; Villat liranca; 1,isbon ; Jureka ; Messinat. 'The fruit is pickel before it colors, and placed in sliallow cnring-trays until ready for packing. Ijach fruit is cut, instead of being pulled, froin the tree.

Limi:- $-\Lambda$ valuable menber of the citrus family, although not much cultivated in this comntry. 'The fruit is nsed in nitking cooling drinks, and in the manufacture of citric aciul.

LoQUAT.-This fruit is sometimes incorrectly called "Japan plum" or "Nedlar." It is a sulall, evergrcen tree. Ilardy as far north as Charleston, but will not fruit satisfactorily nuch ontsicle of the orange belt.

MAN(;o.- - lihis tropicil fruit is too temler except for sontliern Floricla, etc.

MIULBERRY. - Not grown commercially, but everybody should have one or two trees. Downing is probably the best variety, but it is not entirely hardy 
much north of Philadelphia. New Mmericin is the most promising viriety for northern locilities. Russian is most hardly, but the frnit is not so good as Downing, etc. Munlberries mily be propagated by cuttings of the ripe wood.

NECTARINE. - This fruit is practically nothing but a smooth-skin peich; it is not so popular as the pencli and is not much grown except in Cilifornia.

OLIV1:- $-\Lambda$ commercial success only in California.

ORANGE.-In California the orange industry has reached enomons proportions; and in Florida the business is ripidly recovering from the disistrons freezes of a few years agro,- the centre of the orehard region laving leen moved farther sonth. Sicedling groves are not nncommon, but the most sitisfactory method of propagition is budling upon sonr or sweet orange seedling stocks. "Trees shonld not be set deeper in the ground than they were in the nursery," says a prominent grower. Cnt back the head severely ind trim the roots. $\Lambda$ fter the tree is well started but little proning is recuired,- except to cul ont dearl or crossed linibs, and waterspronts, etc. A loose, nellow, well-drained soil, free from hard-pin near the surface, is desirable. The trees need plenty of potasls and phosphoric icis, and not too mucli nitrogen.

I'rincipal insect and fungous trombles: 'the rustmite, red spider, meily bug, leaf roller, citerpillars, aphis, anl the "purple," "long," "red," "circular," "white," "riblued," "broal," "black" and Sin Jose scales, are all enenies of the orange grove, and are fought with the usual renedies-whale-oil soap, kerosene enulsion, arsenate of lead, line-sulplurr-salt, etc. 
"Foot-rot," " (lie-back," limb-blight, scab, etc., all require special treatment, if present.

Varieties: Some of the most popnlar varieties in Floricla are: Indian River; Centennial; Tardiff; Ilonıosassa ; Jaffa ; Majorca ; l'arson Brow11 ; Satsu111a; Dancy; King (the last three are Tangerine or "kidglove" varieties). In California the Washington Navel orange is, of course, the most popnlar; Paper-rind (St. Miclıael); Jaffa; Mediterranean Sweet; Malta Blood; etc.; and sone of the Tangerines, are also planted. Oranges shonld be mature when gathered.

l'A WPAw. - This tree is a native of our centralstates villeys, and is fonnd along the banks of rivers. Commercially it is of little importance.

I'liRS1MmON.-Tlie $\Lambda$ merican persinmon, or, as it is sometines called, "clate plum," grows wild in niany pirts of the Uniterl States. Few attempts liave been made, as yet, to improve it or to grow it on a commercial scale. It is a difficult tree to transplant.

$\Lambda$ foreign variety called Japanese persimnon, or Kaki, bearing litger and finer fruits, is grown in the far Sonth for market. 'Tlis is tot luarly in the Nortlı.

POMELo.-Also called "grape fruit" and "shaddock." A variety of citrus tree which is planted, cultivated, and cared for abont the same as the orange. 

Plate XVIII

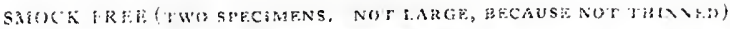

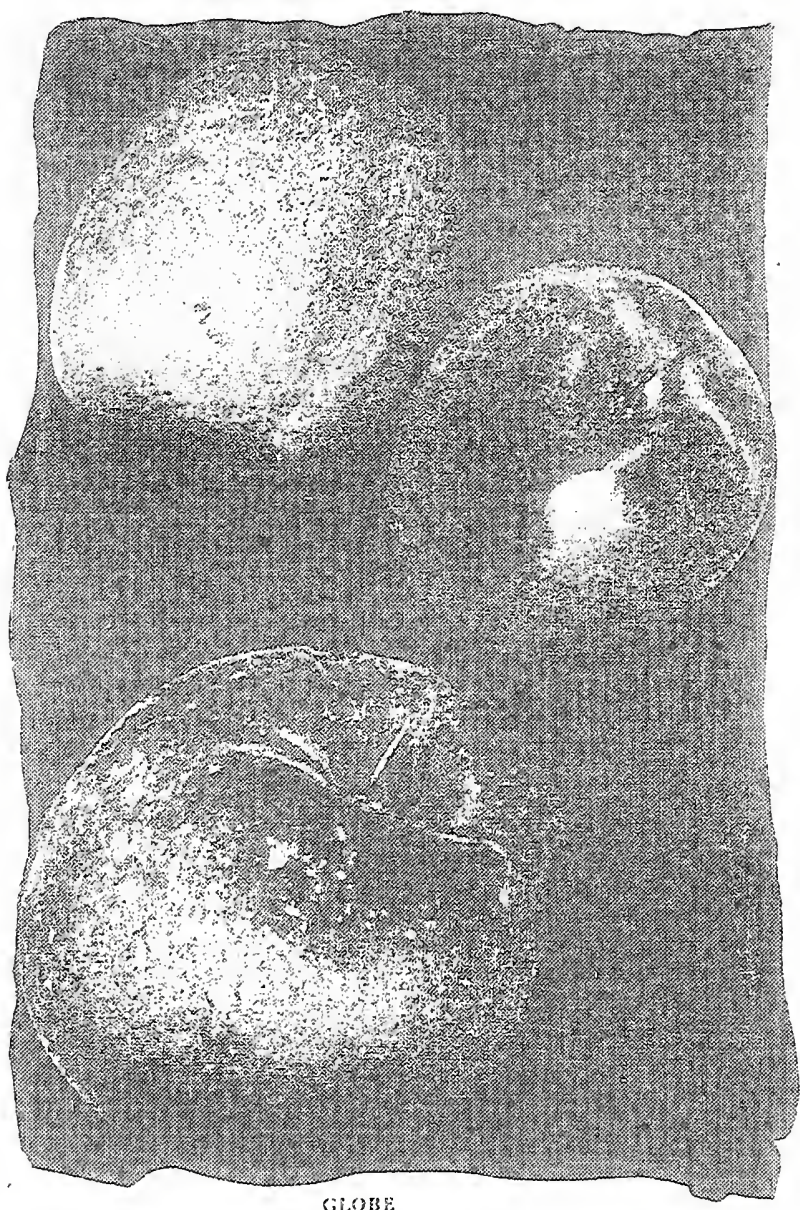

ciiones: 
CHAPTER X̃VHII.

PICKING FRUIT.

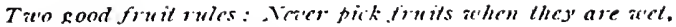
and handle them like egess.-rim.

"Ilow an I to know the riglıt season to pick my apples or peirs?" is a question often asked. The simplest method of determining the mitter is to take loold of a pear or an apple on the tree and grently lemel it nuward. If ripe enomgle to pick, the stem will part from the brinch withont lrealing. But, in aldition to this methonl, the experieneed grower is guided litrgely by the "time of ripening " of ealch variety. liach kind of fruit lats its own scasom for reiching maturity ; callalogs, froit lists and olservation eatsily make hait seatson known to any one who desires the informa- naxipy tion. The appearance of the fruit, and whether tanmis or not its seeds look black and mature, are further guicles. It is important to to the picking only thring conl, eleitr weillerer.

All orcharrlists slomila pick (not pull or slatke) their froit from the trees if they womlal geet the best prices. 13nt, many trees are leing slowly ruined l,y careless picking - the kind thit pulls off the little spur that has developerl the fruit, which if left will develop fruits in after yeirs. There is a slangliter of these spurs in most orchirds. Grisp the apple or 
pear firmly, as indicated in the cut, and give an

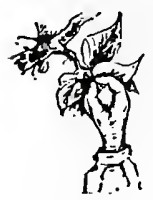
upward bend of the wrist; then the fruit comes off with only the stem attached. No time will be lost, either, in thus doing the picking right, and the stems will be left on the frnit - as they shonlal be.

Apples should be ripe, but hard, when picked. In the latitude of Philadelphia the nain-crop winter varieties are usually gathered in early October.

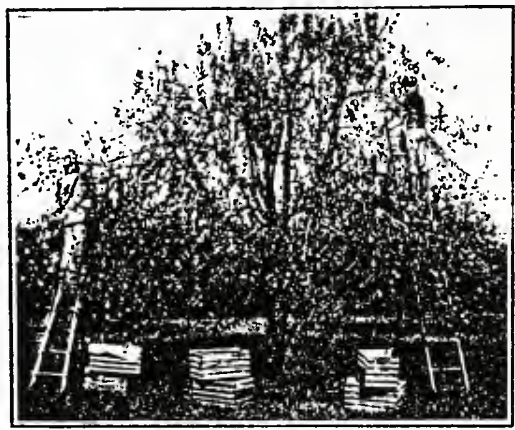

THE FRUIT IIARVEST

Pears, oin the contrary, are still green when ready to pick. 'They are mature but not ripened,-the coloring process shomli come after they have been taken from the tree; this insures better eating, keeping and shipping qualities.

CHERRIES. - The prilicipal points of importance are, care in picking the fruits with the stems on, and 
in not pulling the spur off to which the stem is attached, silys T. A. Farrand, in a special report to the Anerican l'onlological Society. Throw all inferior, bruised or decayed fruits on the gronud rather than in the basket, and thus avoid a nunssy lot of fruit for the packers to cull over. IIave good ladclers and pick all the fruit you can from thence, ratlier than climb around in the tree and break the limbs and fruit spurs.

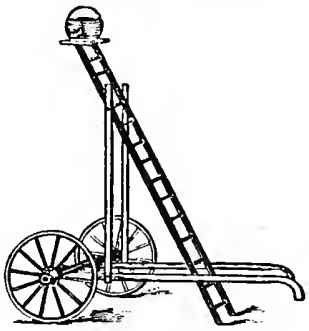

FOR JIIGII TREES Two pickings, with an interval between, are usnally all that are necessary to clean np the tree. One of the niost successful Micligan growers, Mr. Benton Geblıart, liarvests all lis clierries, both sweet ind somr, by spreadling slieets nucler the trees; the pickers then clip the fruit of with scissors, leaving about a half-incli stem with the fruit, allowing it to drop on the sheets. Mr. Gebliart is far better satisfied with this method than with the nsıil way, as there are no fruit spurs pulled off as in picking. 'The pickers are well satisfied to do the work in this way. The fruit is sorted from the sheets into the market packages, and Mr. Gebhart clains that lie gets on an average seventy-five cents nore for a sixteen-quart crate of clierries with clipped stems than for unclipped. It takes fron two, to two and a lialf, quarts n11ore of clipped sten fruit to fill a sixteen-quart crate, than where the whole stem is left on. Cherries (particularly the sweet varieties, whicl are very subject to rot). 
are quickly perisliable and must be picked the instant they are ready. Delay means loss by birds and rot.

PEAcurs. - '’o deteruine "just when a peach is ready," repuires a little observition and experience. For slipping purposes the fruit should be ripe, but

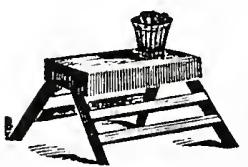
hard, - the degree of liardness depending upon the distance the fruit must travel. Niny expert peaclı growers "go over" eacli tree at least twice; and, often, three or

micking mencu font times, at intervals. Why? Because peaches seldom ripen evenly on a tree, and, by the time all were really to pick, some would be too soft for shipment. l'eiclies, like clierries and plums, are quickly perislable and therefore nust be handled promptly and at just the right minute. Iiacl variety has its own ripening time, and by dividing an orchard into, say, six kincls which ripen at intervals of about a week apart, the orchardist is enabled easily to handle one variety before the next is ripe. This is a great point in large orcluards where competent help is hard to get, - spreads the picking and packing over six weeks, instead of crowding it into only one or two.

PLums. - If possible, pick plums, for market, "witl the stems on." The fruit

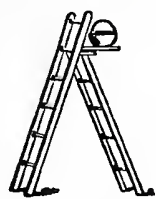

For LOW TREES slould be ripe, well colored, but not soft. If rot threatens (as it often does), the sooner you can pick the crop, the better. Don't delay a moment. Watch for the right time, and then linrry matters. 
QUinces. - A quince should be ripe and well colored before it is picked. Green specimens are not very attractive to the averige buyer. If necessary, pick the trees several times, at intervals, so is to secure all the fruits in a proper condition.

\section{FikUIT SPURS.}

Better bruise your shins than your fruit.

If possible, pick fruit during the cool of the day; and aroid picking during extra lot, murky disys.

For home nse, let peaclies and plums thorouglily mellow and ripen on the trees. Int this won't do for fruit which is to be slipiped.

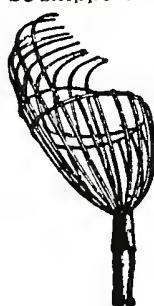

FIG. I

Iiruit should be sct in the shade or taken to the packing liouse as som as pickert. Don't let it sull-cook. Get it cool and $\mathrm{kecp}$ it cool.

Figs. I and II sliow two styles of long-liandled fruit pickers which are sontetinses nsal for liseli-up fruit. jig. Il has a callyis cluite arrangeinent for letting the fruit down into the picker's hand.

With citlier apples or pears, one picking is usually sufficient to secure all the fruit in proper condition. Sometimes, however, it pays to pick

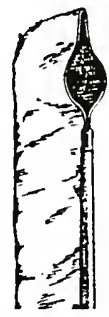

F1G. II

the larger, more mature specinens first, and then clean up the tree a few days later.

look to the safety of the fruit ladders. A rotten spot may neal a broken les or arm. Irequent conts of paint will preserve the somindiess of the wood. Jn this chapter will be fonnd several pictures of different styles of picking ladalers.

Do not handle fruit more than is necessary. The natural bloon shonld be left on. And endeavor to pick apples, pears, etc., before winds blow many of thent off. Pick the ontside trees first, as the inside trees in an orchard are more protected from the wind's force.

Do not squeeze peaches on a tree, to see whether or not they are sufficiently soft to pick. Decay swiftly follows snch treatineit. Expert pickers soou learn the knack of "feeling" of a 
peach withont really squeezing it. The eye, and this delicate sense of tonch, become trained to work together.

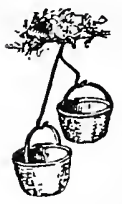

A basket lumg from the rounds of a ladkler is inconvenient to reach. Fit an ironin the sliajeshown in the cut, and your can then luave your basket at the side of the ladder, in the handicst of all positions. A few wooden pcrs IIp and dowil the ladeler will keep the irou from slipping. A blacksmith can make it in a few minntes. And licre's the picture of a double-basket holeler

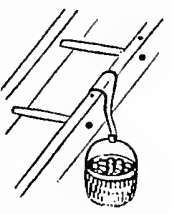
for luanging on to a tree limb.

Wilmer Atkinson says: "We pick all somd apples from the trecs into tin pails, gently pour into slatted busluel-crates, aud take them to our cool apple mow' (once a hay mow). 'I'lis storage place has been double walled and lined, and keeps our winter apples until May. We do the sorting in the winter." (See Chapter XX for further particulars about this simple method of cold-air storage. -J. B.)

A well-kuown l'ennsylvania applc grower has issucd to his men the following printed rules for picking: 1. Pick lower limbs first. 2. See that the ladder is pushed into the tree gently so as not to knock off or bruisc the fruit. 3. J lang the kettle or lissket so as to he alsle to pick with both hands. 4. Jay the apples in : do not drop or throw them. 5. Pick no specked apples. 6. Pick no small, grecn ones. 7. Do not take much time in picking a few little apples ont of reach,- let them go. 8. In emptying, ponr gently, as you wonld cygs. 9. Jo unt set one basket or crate on another so that the apples luclow will be hruised. 10. I, ift and set downl gently all filledl crate's. 11. Ise spring wagon in hanling.

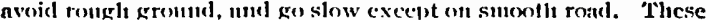
rules are necessary for the proper larvestilig of the crols.

"U hen swrallow's on the har" roofs merch, to chatter of thrirfieht. IVhen hints of fiost a ve in the atr, and crickets chirpat uight; Then come the pleasant day's w'e love in Autumn's mellow prime. The jolliest day's of all the yea, the apple-picking time.

For the ladrn boughs are bending lowe'er all the orchaid atays, The a phles' cherk's are bu'ming ird, and faller' smiles, and says Some starkling morn: 'I think today ne might as mell beginhe smant now, boys $/$ you'll need a week to get those apples in." 

PLATE XIX

CRAWFORI'S I.ATE
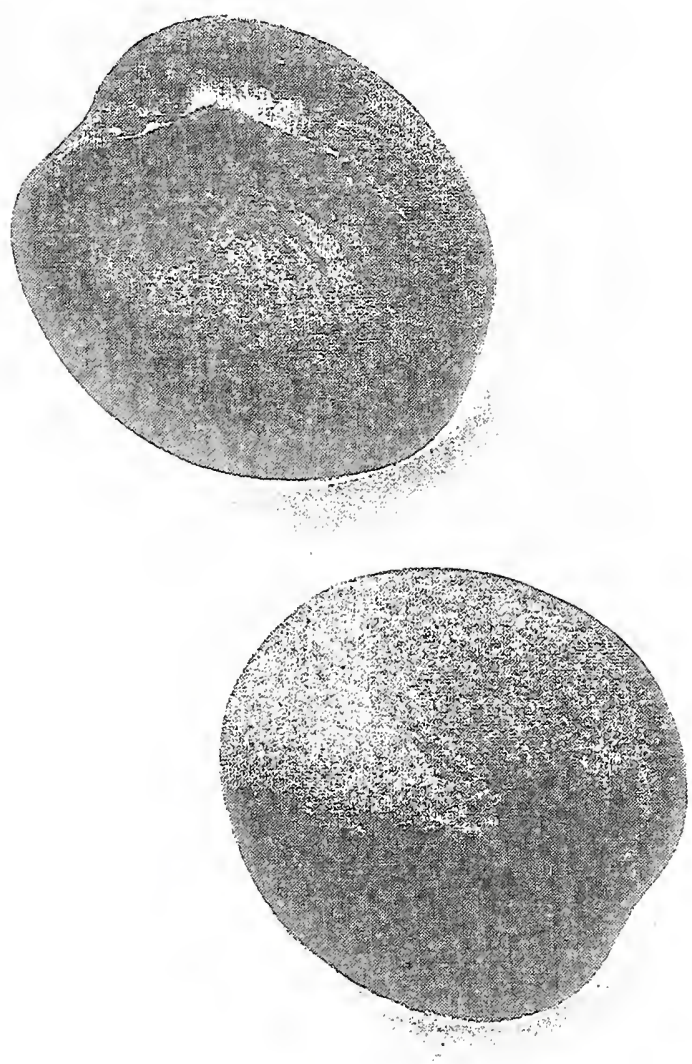

ELBERTA 
CHAPTHR XIX.

\section{(IRIIING ANI) PACKING.}

Instead of a corcless apple, are need onc that is as big in the middle of the barrel as af the ends.

The packinge that lias been most commonly nseal up to the present tine, for apples, is the harrel. 'The stimdiral of size is not nniform thronghont the apple region.

Mlue New York law calls for a harrel with "lieal dianeter seventeen and one-eightli inclies; lengll of stave twenty-eight anul one-half inclies ; bulge not less than sixty-fonr inclies, ontsile measurenents."

The Missouri barrel is as follows: "l,engtli of birrel twenty-eiglit and one-half inches, with clines of three-fourtlis of an incli at the encls; the dianeter of the lieals shinll be serenteen and one-fourth inclies ant the dian11eter of the centre of the barrel insicle shill be twenty and one-linlf inclses."

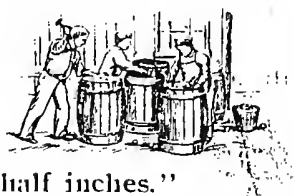

-The Camalian barrel for export apples is recpinired liy law to be "Awenty-six inches and one-fonsth hetween the lieads, inside measurenents, and a heal dianueter of serenteen inclies, and a midalle dianeter of eigliteen inclies and one-hialf, representing as nearly as possible ninety-six quirts."

The barrel recognized by the National AppleShippers' Association is seventeen and one-eighth inches in dianneter of head, twenty-eight inclues in 
length of stave, and bulge not less than sixty-four inclies, ontsicle measurement.

The harrel shonlul be well made, clean, neat and attractive. The statement is sometimes made that the "packige sells the fruit." While this mity not be strictly true, still the package, making as it does the first impression, favorible to the product or unfavorable, has much to do witl disposing of its contents. Under no conditions should the batrel be molersized; it slould give full measure as determinel by law or the custom in the region from which the fruit counes.

BOXFS FOR APPLES.-Dining recent years the busliel apple box has been bronglit into prominent notice. Probibly the box has come to staty and will continue to grow in popular faror. The strong point in firor of the box is that it stits the neerls of the small honsekeeper. Many hesitate to buy a harrel

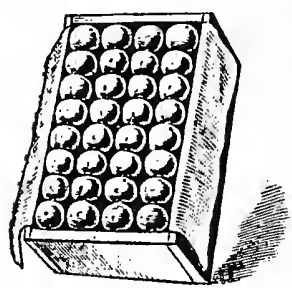

Hox 1 :1) AlPt.1:S of apples who wontll be glinl to get the simme miterial in a smitller package. But the box shonlal not be nserl for anything lout strictly first-cliss fruit; it will not paly to pack inferior or even ordinary apples in a box. 'The boxes shonld be neat and attractive, insicle and ont - the best that cait he prothced in every respect, package and contents.

'The ordinary size of a bushel apple box is $10 \times 11 \times 20$ inches, insicle measurement. 
PACKING Ilouse.-A portion of the barn may be arranged for packing fruit, or a special shed or packing honse may be erecterl. Some growers do their packing on tables placed in the shade in the orcharl. lathled tables witl sloping tops and rin sicles, are very helpful aids to the sorting or grading operation. Jincleatvor to lave the packing honse or place as cool as possible.

GRADING APPI.ES. - Thiree gracles are sufficient, or rather, two grales and the cull-lieap. I believe it best to follow the standarl of size as deternined by the National $\Lambda$ pple-Slippers' $\Lambda$ ssociation, says Mr. 11 . II. IInue, and their remarks on quality are guite in place: 'The standard of size for No. 1 apples of large virieties, such as York lmperial, Staynum, Roune Beanty and Ben l)avis, is set at not less than two and one-lialf inclies in dianeter. 'llie standirrl of size for No. 1 apples of the smiller varieties, such as Winesap, Jonatlan and Bonnun, is not less tlan two and onefonrtl inclies. $\quad$ III No. 1 apples slonlu be practically free from worn-lioles, bruises, breaks in the skin, and

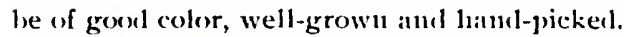

No. 2 apples are those which are not less than two and one-fonrth juclies in clianneter. 'jlie fruit nunst be free from bruises ancl breaks in the skin. 'The size of No. 2 apples of the smialler sort lias not heen fixed, but two-inch dianeter apples might he jucluted.

The stems slonla be in all first-class apples, or $j$ at least eighty-five or ninety per cent. of then, and the specimens in a lot of this kind slonld be miform in size, color anıl appearance. The fruit may be yrimled as it is packerl. 'Two barrels sliould be set 
up-one for No. 1's, the other for No. 2's - and as the fruit is picked over, each class finds its way into its respective harrel. Whether this work slionld be done soon after picking, or later dinring the winter, depends largely upon the grower's own methorls. Wilmer Atkinson prefers the latter way (see precerling cliapter). One thing is certain: It pays to grade fiuit. Most of this grading is done by "liand and eye" ; machine graders are sonetimes nsed.

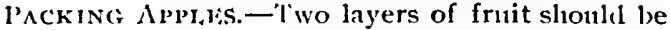
placed in the botiom of barrel, with stems down aml as close together as possible. These will form the

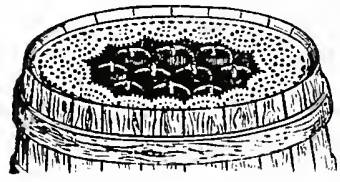

FANCY APPLE-PACKING

facing, for this end will he the top when opener. Iill in with the sanne gratle, of ten sliake, and when near the top put in two ninore lilyers witl stens np, letting the last layer stand a full incli above the chine of barrel. Now put on lid and slowly press into place, sliaking the barrel in the neanwhile.

Some packers place a romul, corrngated paper cushion beneath and on top of the frnit in each barrel; sone use no cuslion of any kind; otlıers use ordinary paper; a few clecorate the top with an exlying of white lace-paper, in aldition to the corrngated cushion. For filling the barrels, a sull basket, one that will go down into the barrel, and provided with a swing handle, will be fonnd very convenient. This basket is filled with fruit, let down in to the barrel and turned over, allowing the fruit to run ont. 
A barrel header, sich as the stores sell, is a liandy implement to own. But if there are only a few apples to be barreled, it may not pay to buy a press. One can be rigged very quickly by using a plank or scantling with one end muler a stud reaching to the slien plate ancl tenporarily nailed in place. The larrel to be HOMr-Mame BARREL pREss lieated forms the fulcrum. Be careful not to press the apples tor hiaril.

Apples in loxes: Iiach apple slould le put in place hy liand-in rows and tiers (like oranges), every apple perfect. 'Tlie number and arrangement of rows depends npon wliat size apple is being packed ; each size will require a clifferent method of "placing to fit." Sonsetimes the rows will neen to be diagonal or irregular; a little experimenting, practise and "kuack" will soon determine the best way to make a size fit a box and "conne ont right" on top. livery apple in a box slould be uniform in size. Sonne packers line the boxes with white paper; and some wrap each apple in paper male for the purpose.

Stenciling apple packages : $\Lambda$ s soon as the packane is closed up and securely mailed, it should be properly marked. The box slionld be marked on both ends, while the barrel shonla be marked on the faced end intended for the top. Both sliould bear the name of the variety; the grade of apple, whether No. 1 or No. 2 ; the name of the grower and the place where grown. 
Ilandle fruit like eggs-with care. Ion't mix different varieties, shapes and colors in one package. 1)n't mix winlfalls with haml-pickerl fruit.

CMIRRIIs.-Baskels not larger than eight or ten ponncls should be used in picking. The packing house should lave tables or frames with canvas bottoms, on which carefully to lay the clierries for sorting into packages. The frnit in the pickage shonla be niniform throughout and tastefully faced to attract the attention of the fasticlions, who will pay the highest market price. In California, sweet cherries are nsmally packed in shallow, small, woolen boxes holding abont ten pounds, and the fruit is carefully sorted and faced in regnlar rows - stem end down and ont of sight. 'ilie effeet is very pretty, but such packing repuires labor and time; it molombtedly pays, however. In the Iiast, sweet cherries are commonly packen in ordinary quart berry boxes, sixteen (or more) boxes to the crate. If the top of each box is properly ficed, the effect is grood; but not so grood as the Callifornjia pilckinge.

Sour cherries are nsinally packed either in eightpoind grape baskets, or in the (nart hoxes mentioned in the precelling paragrapl. The top layer of fruit should be placed, stems down, in regular rows. (iirls or women cin alo this work nicely. The extra expense of thus facing a basket of cherries anomnts to abont four cents. Does it pay? As a rule, yes. A Michigan friend of mine does even more: He packs his clierries in quart boxes in sixteen-quart crates, and along the top edges of crate, folded down over the fruit, he places a narrow elging of white lace-paper, 
- something similar to the exlging often seen on cimly boxes. 'The elging he uses is abont two inclues wide aml costs "less than a cent a crale." 'llen, with a small chister of fresh cherry leaves placed in the centre of fruit at ench crate enel, he comsiders that the job is complete. II is fruit certainly does look remarkably nice, and the prices received for it are extra gool. II is name anl gliantee go on every crate.

P'1:ACII:S. - Different peach-growing alistricts have different stylesof packages. In Micliggan, for instance, the favorite packinge for peaclies is the sixtli-busliel Climax basket witl extension slat cover; in New Jersey, ligli, rollul, flaring-tol, laskets are in favor, lobling alout litif al linsliel; in Georgia, the six-balsket crate

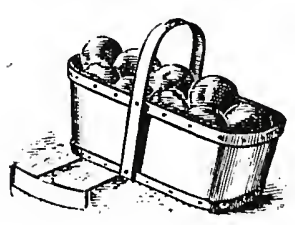

CI.IMAX PRACH-IMSKIET

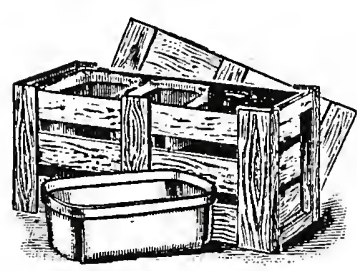

SIX-HASK FT H:ACN CRATI

is the thing, eacli basket holding about four ruarts. Then there are four-basket crales, open-sided peck Climix baskets (for fancy fruit), fifti-1msliel Cliniax baskets, romul busliel baskets witl slat covers, etc., etc. "Whiat package to use" is largely a matter of locility and choice.

I'eaches are uswally graded in to three or four sizes, and each size is packed by itself and labeled accordingly. Machine gralers do excellent work, and are often nsen by large growers. In the Michigan and 
(ieorgia baskets, the peiches are fitted into regular rows and tiers, all arranged "just so." 'The litgest or first-grade peaches are often libeled "l'ancy" or "Selects." Red tarletan is sometines fitted over eacl

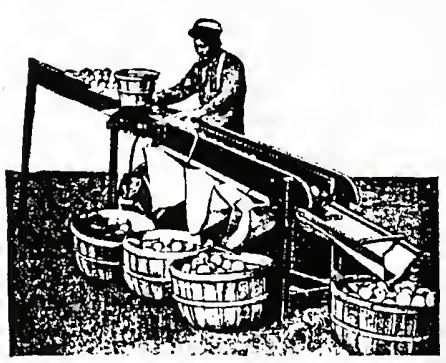

a maciline peach-Grabi:k basket, giving the frnit a pink, pretty, but rather deceptive look.

I'HARs. - I'h is fruit is nsuilly packed and slipped while still in a green state. Bushel boxes, barrels, romind busliel or lialf-buslielbiskets, kegs, etc., are favored by different growers and localjties. The ripening is nearly always done by the dealer. Grading must be done by hand and eye; I have not yet heard of a successful macline grader for pears. Fancy fruits should each be wrapped in paper,-Califormia style.

I'LUMS. $-\Lambda 11$ sorts of packages are nsed for this fruit; it cloes not seem to lave an inclivilual packige especially arlapterl to its nee(ls. P'eich biskets, gripe baskets, strawberry boxes in crates, etc., elc., are all ised. Iiaclı grower has his own preference; and, of course, the style of package cliosen should depend largely upon the distance it must be shipped.

Quincis. - Barrels, lialf-lairrels, busliel baskets, etc., are all suitable for (quinces. liach fruit slould be well colored, mubruised and perfect. Make two grades or sizes. I'se the culls at lione. 

PLATE XX

\{ONBAR

COES GOIARX IBROE

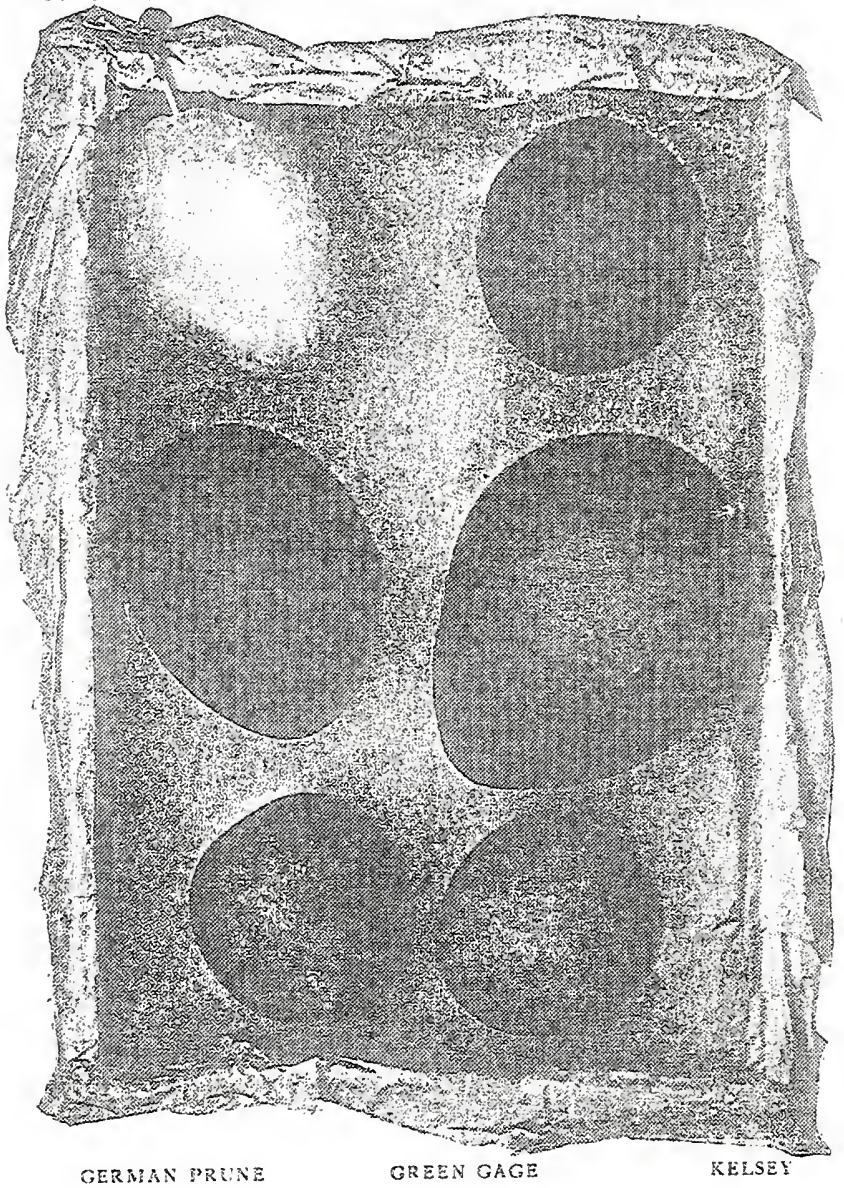




\section{CIIAPRIR XX.}

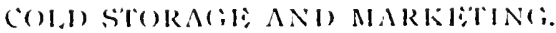

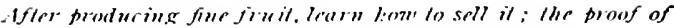
llie selling is in the size of the cheque.- liarmer vincent.

It is not advisable, in my opinion, for the average fruit-grower to use ice for coll storage purposes for winter apples, etc., - it least in the latitule of I'hilatelphia and northwarcl. In Chapter XVill I relerred to Wilmer Alkinson's colıl storigre method, andl I willt (n) sily more abont it, now. Here is at

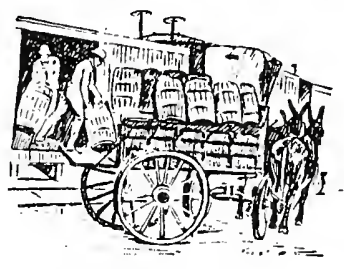
copy of al letter from him, dited octoler sil, ly)(, in which lae gives particulars alont the methoul:

"On Mlonlay" we begin to pick onr crop of Mayfield apples and expect to have between $4,0(x)$ and $5,0(00$ bushels. 'the orchard has just conte into bearing, this being really the first crop. Ilaving a very large baru, much of the spatec contained therein is atritable for storing otlier things than haty, wheat, cetc.; so I have converted a $110 w, 25 \mathrm{x} \cdot 10$ feet, into two storage rooms, one alove the other. It is a stone barn with thick walls, sufficient, with a little lining inside of thick paper (on two sides), to keep ont frost. I have also doubled the wooden walls on the other two sirles, with felt between, and now liave what $I$ deen to be an adnitrable place to keep winter apples, - up to the first 
of $\Lambda$ pril. 'The two rooms will hold, I think, my entire crop. Three donble doors are male in eacli room for the ingress of air on cold nights, my purpose being to use cold night air instead of ice for keeping down the temperature. Whenever the temperature ontsicle is colder than it is insicle, the doors will be opened and the air let in; the cloors will be all closed when it is warmer ontsicle. We expect, before Octolser is ont, to gret the temperature down below fifty degrees and keep it there through Novemler; and by Inecenlier we can easily get it clown to thirty-five. Were I going to build a cold storage louse for winter apples 1 slionld do it upon this principle and not bother with ice at all. But the walls must be tight, donble, paper lined, and with an air space between. Ileat must he kept out, eold must he kept in. (Jpen the doors and let in cool niglit air ; close them during warm days. 1nring the winter if the thermometer sinks to zero or lower, and stays lown for three or four clays, as it sometimes does, it may be necessary to leave a lighted lantern or small oil stove in the storage room during the cold snap, so that the fruit will not be frozen. Apples thus stored keep all their good flavor,-which is more than I can say for fruit stored in ice or ann110niacooled buildings."

I happen to know that Mr. Atkinson has subse(mently provel the truth and success of his plan, and I can heartily recommend the iclea to otlıer fruitgrowers. 'This methoul will keep gool winter apples as late as $\Lambda$ pril 1st. What more is necessary? I cin1 see no advantage in later keeping of apples. After $\Lambda$ pril, apples come in to conpetition with strawberries, etc., and are not 11sually very mucl wanted; besides, 
the average grower hasn't time, after $A$ pril, to attend to the proper marketing of apples-he is too busy with the spring work. Ant, too, many growers can not afforl to pay the charges demanded by some of the hig refrigerating plants.

l'ears will not keep nearly so long as apples, and are usually all marketel, green, early in the season.

SELLING FRUIT.-J. II. Hale says: "Get a good dealer and tell him you liave a good thing. IIave your commission man go and see your place. The business sicle of fruitgrowing nueans belief in yourself and then making those with whon yon trade believe in you."

II. II. Ilume says:-" "The best plin is to gret in tonch with fruit

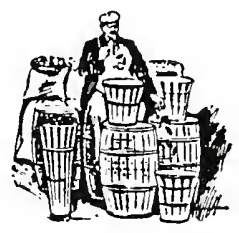
dealers or commission new in good markets and get them to handle the fruit. lither ship to them on consignuent or sell to them ontright. Pick good, reliable men; send then good materiai, treat them squarely, and you will receive like treatment in return."

Another good way to sell fruit is to secure a number of personal, retail customers to whom you can sell direct. Or make arrangements witlı stores.

In sone localities and with sone kinds of fruit, it is possible to sell the crop, on the trees, for a lump sumt per acre or for the entire orchard. The buyer does the rest.

Oftentimes buyers will buy an entire orcharl's prodict, and agree to pay so mincli per barrel for.firsts and so mucli for seconds; or they may offer so much per barrel "as the fruit rums." Sometimes the arrangement is that the grower is to doall the picking, 
graling and packing, and deliver the fruit at the nearest railway station or steamship wharf.

Wilmer Atkinson's method is to store the fruit until winter or later, and then gradually sort, pack and warket it during the leisure months.

"Central Packing Ilonses," "linuit-Growers' Iixclıanges, " "Co-operative Marketing $\Lambda$ ssociatious," etc., have heen more or less snccessfully operated in California, Michigan, Wisconsin, Colnden, Ill., Springfielı, Mo., Maryland, Georgia, etc. 'These concerus are usually incorporated, and the surrounding fruit-growers own stock aud control the management. Such mutual associations, when riglitly officered and conlucted, are of ten a great blessing to a fruitgrowing community. Instead of, say, one lumulred different brancls in one locality - all different and all competing agaiust ench other in open market - there is (where a central packing and selliug concern exists) just one brand. $\Lambda$ ul this one brand, heing all graled and packed uniformly and in very large lots, can be sold to hetter advantage thas a diversified prodnct.

Well, IIarrict hints that it is time for me to stop,that this hook is alrealy too long. So, while she looks over my shouliler and nods her heal enconragingly, I helieve that I had better say : "Gool-11ight."

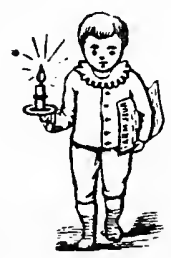




\section{INIEX}

$A \quad 1 \times 1 ; 1$

Ake al which liees henr, . Is

Alfilfa iu orelamils, . . . 77

Alumbl, . . . . . . 115

Aphis, . . . 83, 92, 96, 108

Aplis, woolly, . . . 35, 85

A pisle. The. Ciulure Pests: 1'ruliug: Siprayiug; Variclies; etc.. . . . S1 to 90 Apples, cold storage and markcling. . . . 13710140

Applcs, crat,. . . . . 119 Apples, grating, . 131, 132, 133 Apples, packing, . . 129 to 133 Aploles, picking. $123,124,127,128$

Apricot, - ..... 119 A rsenale of lead and soda, 63 Aslies, hard-wood, . . 55, 78 Avncaclo or Alligntor pear, 119 8

13ark-luurst, . . . . . 91, 110 llark crafting, . . . . 23, 24 lsark injury, preventing, $77,78,79,80,91$

"13arked" Irees, saving, 24, 58 liarrel juress, . . . . . 133 liarrels, apple, $129,130,132,133$ liaskets, packing, 134, 135, 136 liaskcts, picking, . . 128, 134 llecell 1111, . . . . . . 115 13c.01la.

(Sice May Beclle, etc.)

Jircl injıry, . . . . . . . 94

Isilter rol, . . . . . . . . 85

lilack ki1ot, . . . . 93, 109

IHlack spot, . . . . . . . 86

Black walıust, . . . . . 115

Blight, fire or pear, . . 86, 105

bliglit, leaf, . 93, 104, 105, 110

IBliglıt, twig, . . . . . 86, 97

IHossine facts.

$16,17,44,58,65,77,78,79,96$ Blue vitriol.

(Sce Copper Sulphate.)

Jolts, use of, . . . . . 77

Jone fertilizers, . . . . . 56

Jordennx 111 ixt11re, 61, 62, 65, 66 Borers,

$77,79,80,83,92,96,103,108$

Boxes, fruit, $\cdot 130,133,134,136$

Bridge grafting. . . . 24

Brown rot, . . . 93, 97, 110
I'AC:F

Jindalins, . . 19, 25, 26, 27, 28

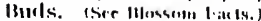

lilel wotiu, . . . . . . 83

Juftalo Irce-hopuer. . . . 83

linttermint, . . . . . 115

j3uying trees, . . . . 14, 16

Canker, . . . . . 86,87

Canker worni, . . . . . 84

Caterbillars, lent, . . . . 85

Cherry, The. Cullure: Pcsts:

l'runiug: Simaving: Va-

rielies; etc.. . . .91 to 94

Cherries, grading, . . . 134

Cluctries, packins, . . 134, 135

Clierries, picking, 124, 125, 126

Clsesturt, . . . 115, 116, 117

Chinçuapiı, . . . . . . 117

Citrolt. . . . . 119

Citrus fruits. . . 119 to 122

Cleft grafling, . . . 21, 22, 23

Clinutic conditions. . . 12

Clover in orcharis, . . . 76, 77

Coconnut. . . . . . 117

Cocoons, destroy. . . . . 77

Colling moth, • . 83, 84, 103

Cold storage, $137,138,139,140$

Collar rol, . . . . 86, 87

Connussion nen, . . . . 139

Co-(1)eralive associations. 140

Copjuct stllplitile, . . 61, 62, 66

Cover cross. . . . 75, 76, 77

Cimurats in orclents. : 76

Crab apple. . . . . 119

Crates,.. '128, 134, 135, 136

Cricket, suowy tree, . . . 97

Crop-growing in orchards. 52,53

Crops, cover, . . 75, 76, 77

Crulclics, weak, . . 45, 77

cromull gall. . . . 34, 35, 98

Crowvil crafting, . . . 24

Culls, fruit, . . . 131, 136

Cultivation, . $51,52,53,54,58$ (See also uniler

Curculio, . . 84, 92, 96, 108, 109

Cut-worms, clinbing, . 42, 43

ID

Dale palın, . . . . . 119

Dearl wood, . . . . . . . 48

Diseases.

(See Spraying; Apple; Pear ; elc.) 


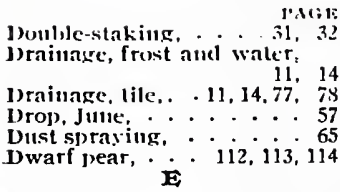

Finulsion, ketosene, . 63,64

. incing, . . . . 1.32, 1.33, 1.34

fill settiuk, . . . . . . 14

fiertilizalion, hlossom, . 16, 17

Fertilization, soil

$$
17,35,54,55,56.54
$$

lig, . . . . . 119, 120

Filbert, ........ . 117

Filler" trees, . . . . . 30

Fire blight, . . . . . 86, 105

firost al:irni, antonialic, . 74

irost-crnck. . . . . . . 98

Frost draimage. . . . . 11, 18

lirost injury, 77, 78, 79, 96. 99

irnit-bark incelle, . . . . 96

Iruit- bearins, jrenature.

43,44

liruit burkling, picking, varieties, etc.

(See under Juslding; Trcking; etc.)

Iruit-fly, cherry, . . . . 92

lituil-growers' excliankes, 1411

Fitugicicles. (See Sinraying.)

Pintigous discases.

(See Sirny ing; Apule; l'ear; etc.)

$$
\text { B }
$$

Galls, crownand root, 34, 35, 98 Girclled trees, how to avoid.

$$
77,78,79
$$

Girdled trces, saving, : 24, 58

Gouger, pliti11, . . . . 109

Gratiug fruit, . . . 131 to 136

Grafting,.... 19 to 28

Graftilig wax, . . . . . 23

(irease, axle, . . . . . . 78

(ironind, preparation of, . . 17

Gilava, ....... 120

Gitm, . . . 80,91, 98, 110 II

llarrowing, . . . . 52,53, 58

llazelı11, . . . . . . . 117

IIead, alvantages of low:

$40,44,49$
Ilead, forming the

TAGE

$38,39,40,41,44$

Heacler, barrel, ... 133

Ilecling-int trees; . . . 14, is

Ilcl) problem, tine, ... 13

llexagon planting systen, 33

llickory n11t, . . . . . . 117

High ground, inportance

of, ... . . 11

lnsecticilles. (See Spraying.)

Inserels.

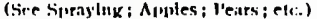

Irrignativis, ..... 54

\section{J}

Ju11c ling, ....... . 93

Jume clrop, . $\quad \ldots .57$

Kainit, .... 55, 103

Kaki, . . . . . . 122

kegs for pears, .... 136

Kerosene cumision. . . 63, 64

Kilot, black, $\ldots 93,109$ I.

Jalicl, tree, ... 42, 44 1,adllers, $\cdot 123,125,126,127,128$ t,adybircls, .... 73 1.cad, arseliate of, . . . 63 I,eaf-blight or spot.

$93,104,105,110$

I,eaf-curl, peach, ..... g7 leaf mite or lilister, pear. 103 1, eif roller, etc., . . 85; 92 lemoll, ...... 120

l,ice. (See Aplis.)

l,ice, scale, . . . 67 to 74

lime, ... . . . 120

I, inle-snlplutr-salt mixture, $68,69,70,73,74$

"I ittle peach."... . 98

"1,ittle Turk." . . . . . . 109 I,ocation of the orchiril,

$11,12,13,14$

1,omnat, ......... 120 M

Masgot, apple, .... 83 Maggot, cherry, . . . . 92 Mango, ....... 120 Map of orchard, $\therefore i 7,42$ Mlarketing fruit, . 137 to 140 Marking packages, ... 133 May beetle, ....... 93 
PAGE

Mellar, . . . . . . 120

Mice injury, . . . 77, 78, 79

Mlidge, . . . . . . . 103

Mtililew, . . . . . . 85, 93

Moisture, conservation of,

Milberry trees. $.94,120,12 i$

Mnlchiıg, . . . 44, 5j, 58

Muzzles, - : * * 58

Nectarine, . . . . . . 121

Nitroge11, . . . 54, 55, 56, 76

Nomales, sprulying, . . . 61

Nitrsery trees, selectius, $16,81,91,95,102,107$

Nit trces, . . . . 115 to 118

Oats il orchards, . . . . . 77

Olive, ......... 121

Orange, - . . . . . 121,122

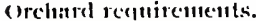

(Sice muder Setting ; I'runlny: Simaving; etc.l

(irckosi wasli, . . . . 70, 71

()verlonritus, ...... 45

Oyster-shcll scale, - 71, 72, 103

l'ackages, fruit, . . 129 to 136

l'ackiug fruit,. . . 129 to 136

Jacking house, . . . . 131, 140

Paper, for lacking, $132,133,134,136$

'itraguil clicstint, 115, 116, 117

l'aris green, . . . $62,63,65$

l'awlaw, . . . . . . . 122

l'ench, 'rie. Culture; l'ests:

Ironing; Siprayiug; Va-

rietics: etc. . . '95 to 100

leaclues, sradius, . . 135, 136

peaclses, joacking, - *135, 136

Peaclies, picking, 126, 127, 128

lear, Jile. Culture; l'ests:

Jrunitug; sitraying; Va-

riclles; elc. . . 101 to 106

J'cals, gradiug, . . . . 136

Pears, narketing, . . 139, 140

l'ears, packing, . . . . 136

Pears, picking, - 123, 124, 127

l'ecall, ..... 117, $11 \mathrm{~S}$

persinmon, . . . . . . 122

Thosplooric acid, . . . 54, 56

Picking fruit,... 123 to 128

racis

l'ink rot........ . 86

planning tlice orchard, . I

Plan of orchard, making a

17,42

l'lanting, . . . 29 to 33

l'lowing, . . . 52, 53, 58, 88

1'lu11, 'The. Cilture; l'esis:

I'ruuiug : Sipraving: Va-

rieties; etc.. . . 107 to 110

Jlums, jacking, . . . 136

Plinns, picking, . . 126, 127

l'uckets, plum, . . . 110

lollinalion of hosisontis.

$16,17,79$

pounclo, . . . . . . 122

J'otoshl, . . . . . 54, 55, 56

l'owdery mildew, . . 85, 93

l'ress, harrel, . . . . . 133

Propayation, 19 to $28,81,91$.

$95,102,107,111,113,117,118$

Irotection,agrinet frost,11, 18

l'rotcetion, ront. . . . 35, 36

Protectioll, solil. (see Cover (rops)

P'rotcetion, witer, . . . . 18

J'runing, litter,. . . 45 to 50

(See atso under Apple; l'ear; etc.)

Pruning newly-set trees. $37,38,39,40,41,44$

Prrming, root, . 34, 40,41, 49

Pruning tools, . . . . . 46

'sylla, pcar-tree, . . . . 104

Pumps, s(urny, and fittings,

Qnince. '1lie, $\dot{\mathbf{R}}^{111,112,127,136}$

Rablit injıry; . . . 77, 78, 79

Rape, lissex, in orchards, 76

Record of varicties, . 17, 41, 42

Red spider, ....... 116

Ripening, time of, . . 123, 126

Riperot,....... 85

Root gall, . . . 34, 35

Root surufting,. . . . . 24

Root protection, . 35, 36

Root prinling, . . 34, 40, 41, 49

Kose bu1, . . . . . . 9 93, 97

Kosette, jeach. . . . . . 98

Rot, collar, . . . . . 86

Rot, frnit, . 85, 86, 93, 97, 110

Rust, . . . . . 86

Rve ill orchards, . . 76, 77 


\begin{tabular}{|c|c|}
\hline & \\
\hline $\mathbf{S}$ & Mt \\
\hline $\begin{array}{l}\text { addle grafting, : * : : } \cdot 24 \\
\text { alt. (See L_ime-sulphur-sait,) }\end{array}$ & 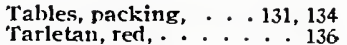 \\
\hline Jose scale, - - 67 to 74 & Tent-caterpiliar. \\
\hline . $86,98,105$ & $\therefore 57$ \\
\hline$\therefore .67$ to 7 & $11,14,77$ \\
\hline its treatment, - & $51,52,53,54$ \\
\hline trunks. $72,80,8$ & cco solution, . . . . \\
\hline . . . 72,73,104 & grafting, • \\
\hline Sectl-growing, $:-19,2$ & ing, . \\
\hline Sclf-sterility, $16,17,79,82,10$ & ini, : \\
\hline elling frui & sliowy, \\
\hline$\cdots \cdot \cdots$ & 42 , \\
\hline ting trees, - . 29 to 36 & [rees, nursery, selecting, \\
\hline
\end{tabular}

Sliceld grafting. . . . . 24

Shot-hole fungus, . . 93,110

Shy-bearing, .....45

Side grafting, . . . . . 25

Slag, Thonllas or basic, . 56

Slug, ....... 93, 104

Sinndges, ..... . 79

Soap, whale-oil. . . 64, 72

Socla, arsel1ate of, . . . . 63

Soils, 13, 82, 91,95, 102,107,111, 113 Sorting fruit, . . 131 to 136

Soy beaus in orchards, . . 76

Splice grafting, . . . . 25 Spraying,... 59 to 74 (Sce also under Apple: Pear:-etc.)

Spring sctting, ... 14 Spurs, fruit, . 1 123, 124, 125 Staking-board, . . . 31, 32 steam-cooking apparatus,

Stems, fruit, . 124, 125, 126, 134 Stenciling packages, . . 133 Stock, the, and its treat-

ment, ........ 21 Storage, cold, $137,138,139,140$ Strainers, . . . 65, 66 Stratification, . . . . 28 Strawberties in orclnards. . 52 Stringfellow method, . 40, 41 Stub, never leave $a, .48,49$ Subsoil, ..... 13, 14 Suckers, . . . 48, 49, 50 Sulphur. (See I.ime-sulphur-salt.) Siti-scald, $77,79,91,98,103,110$ Sin-scorch, . . . 98 Superphosphate, . . . 56

Trees, treatment of

(See under Setting; Pruning;

Spraying: etc.)

'Triangle system of plant-

ing, ....... 33

'rurnips in orchards, . . 76

T'wig bliglit, ... 86, 97

Twig-borer, apple, . . . . 83 $\mathbf{v}$

Varieties, different fruit, $16,89,90,94,100,106,110$ 112. 114, 119

Varieties, 11nt, 115, 116, 117, 118

Varieties, record of, $17,41,42$

Vetch cover crop, ? : 76

Vinegar, ...... 88

\section{$\mathbf{w}$}

Walnuts, . . : . . 115, 118

Wash. (See 1.ime-sulplur-silt.)

Wash, for borers, . . . 80

Wash, Oregon,. . . 70, 71

Water drainage, ...11, 14

Water protection, . . . 18

Wax, grafting, ..... 23

Wcevil, cliestnut, . . . . 116

Whale-oil soaj solution, 64,72

Whip grafting, ..... 25

Whitewash. ..... 88

Windbreaks, . . . 18, 114

wood-veneer, . . . . 79

Woolly aphis, . . . 35, 85

Wrapping fruit, . . 133,.136 $\mathbf{Y}$

Yellows, peach, . . . 98, 99 



PENN STATE UNIVERSITY LIBAARIES

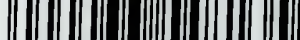

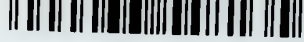

\section{A0000335481 35}

